2016

\title{
The Caddo Archaeology of the San Pedro Creek Valley, Houston County, in East Texas
}

Timothy K. Perttula

Heritage Research Center, Stephen F. Austin State University

Bo Nelson

Heritage Research Center, Stephen F. Austin State University

LeeAnna Schniebs

Mark Walters

Heritage Research Center, Stephen F. Austin State University

Follow this and additional works at: https://scholarworks.sfasu.edu/ita

Part of the American Material Culture Commons, Archaeological Anthropology Commons, Environmental Studies Commons, Other American Studies Commons, Other Arts and Humanities Commons, Other History of Art, Architecture, and Archaeology Commons, and the United States History Commons

Tell us how this article helped you.

This Article is brought to you for free and open access by the Center for Regional Heritage Research at SFA ScholarWorks. It has been accepted for inclusion in Index of Texas Archaeology: Open Access Gray Literature from the Lone Star State by an authorized editor of SFA ScholarWorks. For more information, please contact cdsscholarworks@sfasu.edu. 
The Caddo Archaeology of the San Pedro Creek Valley, Houston County, in East Texas

\section{Creative Commons License}

\section{(c) (i) (9)}

This work is licensed under a Creative Commons Attribution-NonCommercial 4.0 International License 


\title{
The Caddo Archaeology of the San Pedro Creek Valley, Houston County, in East Texas
}

\author{
Timothy K. Perttula, with contributions by Bo Nelson, \\ LeeAnna Schniebs, and Mark Walters
}

\section{Introduction}

The Nabedache Caddo that lived on San Pedro Creek in Houston County in the East Texas Pineywoods (Figure 1) were a prominent nation during the early years of European contact, from ca. A.D. 1687-1730, if not later. Their villages, hamlets, and farmsteads sat astride an aboriginal Caddo trail that came to be known as El Camino Real de los Tejas, and thus their community was a principal gateway to Europeans and other Native American tribes who came from the west in Spanish Texas to meet with the Tejas or Hasinai Caddo peoples. The first Spanish mission in East Texas was established amidst the Nabedache Caddo community in 1690 (Weddle 2012:2)

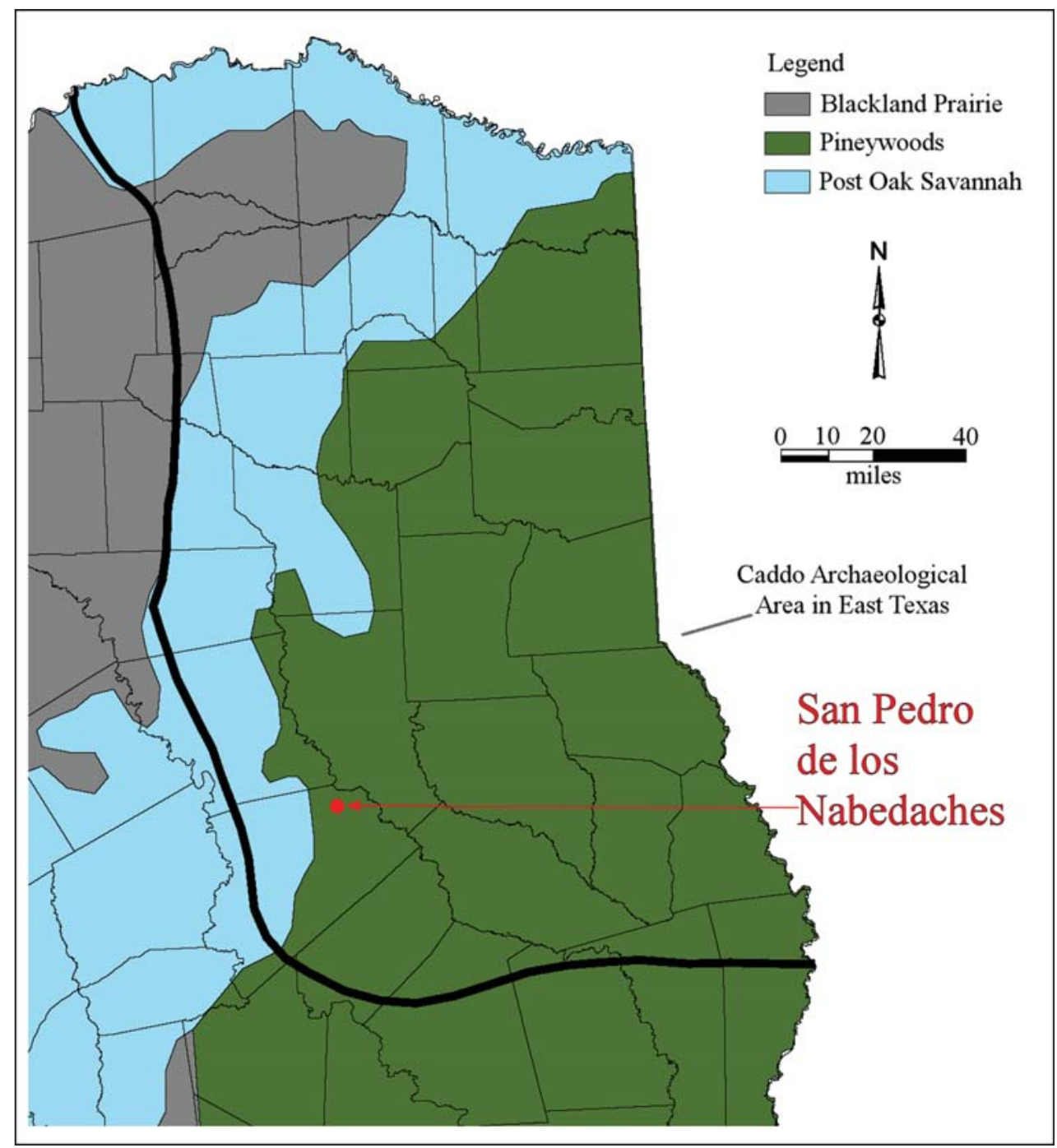

Figure 1. The location of San Pedro Creek sites in East Texas: San Pedro de los Nabedachos. 
According to Swanton (1942:26), Nabedache means the place of the thorny trees with black berries growing on them (beidatco). The "Na" is the Caddo language locative prefix meaning "the place of;" it can also "refer to the people residing at that place" (Chafe 1993:222-223). Rogers and Sabo (2004:629) indicate that Nabedache means "blackberry place." The archaeology of the Nabedache Caddo, or that of their pre-A.D. 1542 ancestors, is not well understood, primarily because of the dearth of intensive investigations at a range of Nabedache Caddo sites that likely occur along San Pedro Creek as well as nearby streams in the Neches River basin. Work that has been completed, primarily on sites at Mission Tejas State Park, have included surveys and limited test excavations at a few sites (see summary in Perttula and Nelson 2006:27-29) that have Caddo material culture remains (sherds from ceramic vessels, chipped stone tools, etc.) and European trade goods, including glass beads, gunflints, lead balls and sprue, an iron hoe, an iron rowel, a possible strike-alight, an iron gun cock, trigger plate, butt plate finial, and gun barrel fragments, iron cast iron kettle fragments, iron knife fragments, wrought iron nails, brass tinklers, and Spanish majolica sherds (Perttula and Nelson 2006:181-185). In this article, I discuss the archaeological material culture remains from ancestral Caddo sites along San Pedro Creek, including those known to have been occupied by the Nabedache Caddo peoples after the mid-1680s.

\section{Historical Context}

When the Caddo Indian peoples living in East Texas were first visited by Europeans in 1542, the remnants of the De Soto entrada (Bruseth and Kenmotsu 1993) described to chroniclers that the Caddo in East Texas lived in scattered but dispersed settlements with abundant food reserves of corn. The entrada moved along pre-existing east-west and north-south Caddo trails through East Texas, and from Hasinai Caddo groups in the Neches-Angelina River basins to Cadohadacho groups on the Red River (Figure 2). The east-west aboriginal trail in most particulars became subsumed within the later East Texas portions of the El Camino Real de los Tejas first established by the Spanish in the late $17^{\text {th }}$ century (Weddle 2012:1-28; Williams 2007:Figure 8).

Archaeological investigations carried out in East Texas since the early $20^{\text {th }}$ century confirm that Caddo communities were widely dispersed throughout all of the major and minor river valleys of the region. The most intensive settlement of the region may have been after ca. A.D. 1400, especially in the Neches-Angelina River basin (Story 1995). By the mid-1600s, the Hasinai Caddo peoples of East Texas were referred to by the Spanish as the "Great Kingdom of the Tejas" because they were considered to be a populous and well-governed people.

When Europeans began to venture into East Texas in the 1680s and 1690s, the territory of the various Hasinai Caddo tribes became well understood (see Berlandier 1969; Jackson 1999; R. H. Jackson 2004). The area known to have been occupied by the Caddo in the late $17^{\text {th }}$ century was also called "Tejas" by the Spanish, while the French called the Caddo in this area the "Cenis" (Figure 3). The Nabedache Caddo villages on San Pedro Creek were the principal entranceway to the lands of the Hasinai Caddo tribes that lived in the Neches and Angelina River basins, and one of the routes of the Camino Real-El Camino Real de los Tejas - came to and through this place from the late $17^{\text {th }}$ to the early $19^{\text {th }}$ century (Corbin 1991; Cunningham 2006). According to Weddle (2012:2):

The Spanish first focused their interest on the Nabedaches with a short-lived mission in 1690 , for it was among the Nabedaches that La Salle's remnant had appeared, just a few years previously, as it sought a path to the Mississippi. Thus, the amorphous Camino Real first directed itself toward the Nabedache village, situated between the Trinity and Neches Rivers. Beginning in 1716, missionary endeavors would be directed at other tribes of the Caddoan [sic] confederacies as well.

In historic times, the archaeology of the Hasinai Caddo groups is associated with the Allen phase (ca. A.D. 1650-early 1800s). "The Allen phase is believed to have developed out of the Frankston phase [ca. A.D. 14001650], and more importantly, to have shared the same form of organization, kinds of inter-group interaction, 


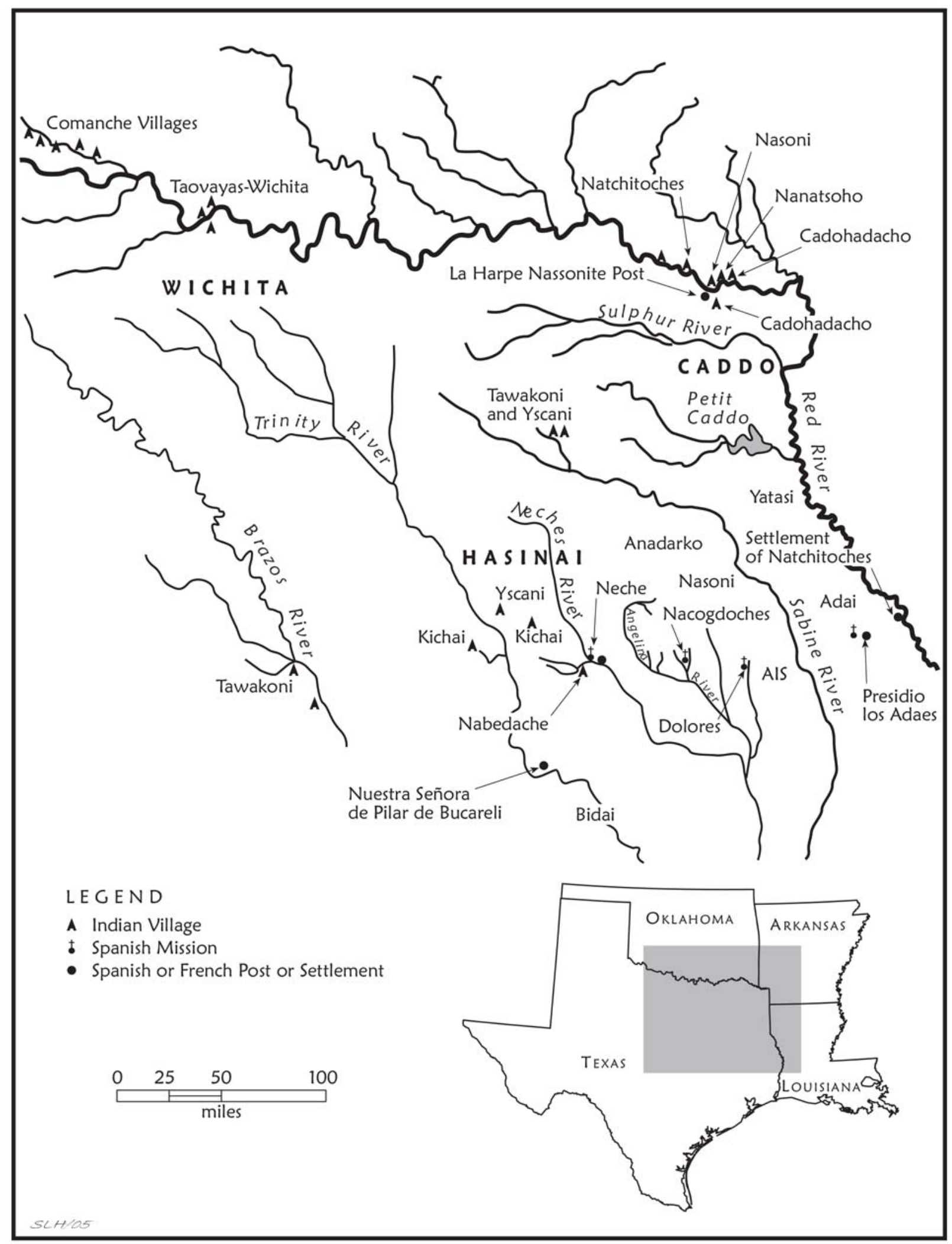

Figure 2. The distribution of Caddo groups in East Texas, as well as $17^{\text {th }}$ and $18^{\text {th }}$ century French and Spanish missions and settlements. 




Figure 3. Redrawn version of Guillaume Delisle Map, 1702, "Carte de Canada et du Mississippi." The Nouidiches or Nabedache lived on San Pedro Creek near its confluence with the Neches River.

and settlement patterns" (Story and Creel 1982:34). The groups who during the Allen phase occupied the Neches (the Rio aux Cenis) and Angelina river basins were direct ancestors of the Hasinai tribes (see Figure 3) who were living in or near the Spanish missions that had been periodically established and maintained in the region between ca. 1690-1731, and they continued to live there until the 1830s (see Jackson 1999:Plate 98).

Story and Creel (1982:32) have suggested that the Allen phase populations were organized in a "weakly hierarchical structure" analogous to the Hasinai confederacy (see Swanton 1942). Allen phase components are found in the Neches and Angelina River basins in Cherokee, Anderson, Houston, Rusk, and Nacogdoches counties (Erickson and Corbin 1996; Middlebrook 2007; Perttula and Nelson 2006; Story 1982, 1995). These Historic Caddo sites contain small amounts of European trade goods found in village contexts, along with a variety of decorated and plain Caddo ceramic wares, triangular and unstemmed arrow points, elbow pipes, ground stone tools, and bone tools. Most Allen phase sites were apparently occupied for only short periods of time, perhaps an average of 20 to 40 years (Good 1982:67-69). 
Allen phase Caddo communities were apparently composed of many farmsteads spread out over a considerable distance. In 1687, in the community of Nabedache Caddo on San Pedro Creek in Houston County (see Figure 3), Henri Joutel noted that:

we took the path to the village where the Indians conducted us to the chief's hut which was a long league's distance from the entrance to the village. On the way, we passed several huts that were grouped in hamlets; there were seven or eight of them, each with twelve to fifteen huts together with space between each other and fields around the huts (Foster 1998:206).

Individual Hasinai Caddo families lived in their farmsteads, and a number of farmsteads were organized into rancherias spread out over about 15-30 leagues (ca. 39-78 miles) of stream valleys and arable lands. Each rancheria was separated from the others by unoccupied lands and hunting territory (Foster 1998:208).

The Spanish were determined to have effective control of the East Texas lands, thus minimizing the French influence, and bring missions to the Caddo peoples (R. H. Jackson 2005:22-23, 26; Wade 2008:107-113). Between 1690 and 1719, the Spanish established a number of missions among the Hasinai Caddo in East Texas, with most of them situated in the middle of Caddo communities and along what became the Camino Real de los Tejas (Figures 4-6). Despite the efforts of the missionaries, the Caddo refused to congregate in the vicinity of the missions, and no Caddo peoples were converted to Christianity; baptisms "were administered to [Caddo] people who had died or were dying, half of whom were children" (Wade 2008:112).

One of these missions was Mission San Francisco de los Tejas (1690-1693) on San Pedro Creek a few miles from its confluence with the Neches River. This mission has never been found, but then again there has not been a concerted archaeological, archival, and historical investigation of the San Pedro Creek valley to identify the site and the surrounding Nabedache Caddo community (see Weddle et al. 2016).

Delisle's map of 1702 (see Figure 3) shows that the westernmost Caddo groups (the Cenis) were living on and near the Neches River, west of the Neches on San Pedro Creek. In the 1720s-1750s, the Hainai Caddo lived to the east on the Angelina River (see Figure 4), while the Nadaco and Nasoni were in communities to the north and west - apparently above the Camino Real-and a series of Cenis or Hasinai communities were along the western boundaries of their territory. The San Pedro or Nabedache Caddo were living east of the Trinity River and west of the Neches River (see Figure 4). At these times, Spanish missionaries were living in the midst of certain Caddo peoples at Mission Nuestra Senora de los Nacogdoches and Mission Nuestra Senora de Ais (see Figure 5). A 1771 map by Jose de Urrutia show Caddo groups living north and west of these two missions (see Figure 6). The missions at Nacogdoches and Ais were abandoned in 1772 and 1773 , respectively.

Because of the regular outbreaks of epidemics among the East Texas Caddo, especially outbreaks at the Spanish settlement of Nacogdoches in the late 1770s and early 1780s, Caddo populations declined precipitously through the colonial era (Table 1). Caddo groups moved their villages, or coalesced into one village for protection. The Hasinai Caddo groups - the Nacogdoche, Hainai, the Hasinai, the Nadaco, Ais, and the Nabedache - remained in their East Texas homelands, living in the early 1800s outside of the Spanish settlements of Nacogdoches, west to the Neches River, and apparently north of the El Camino Real (Figure 7). Between about 1836 and 1839, the Hasinai tribes had all been forcibly pushed out of East Texas, and they either moved to Indian Territory, or farther west in Texas (in the upper Trinity and Brazos River basins, see Neighbours 1973, 1975). 


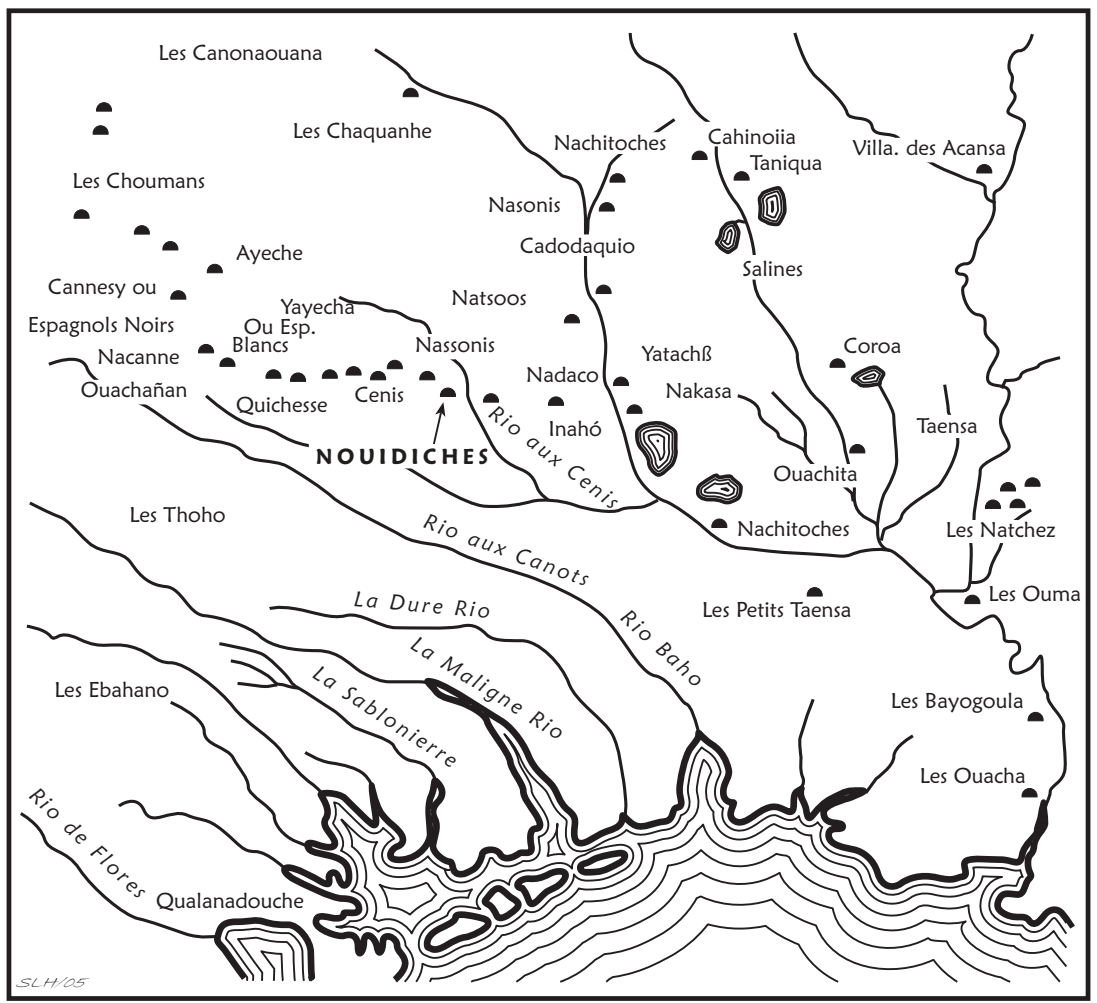

Figure 4. Redrawn 1740 map of East Texas, Sandoval and Franquis map (Jackson 1999:Plate 34 and Figure 5).

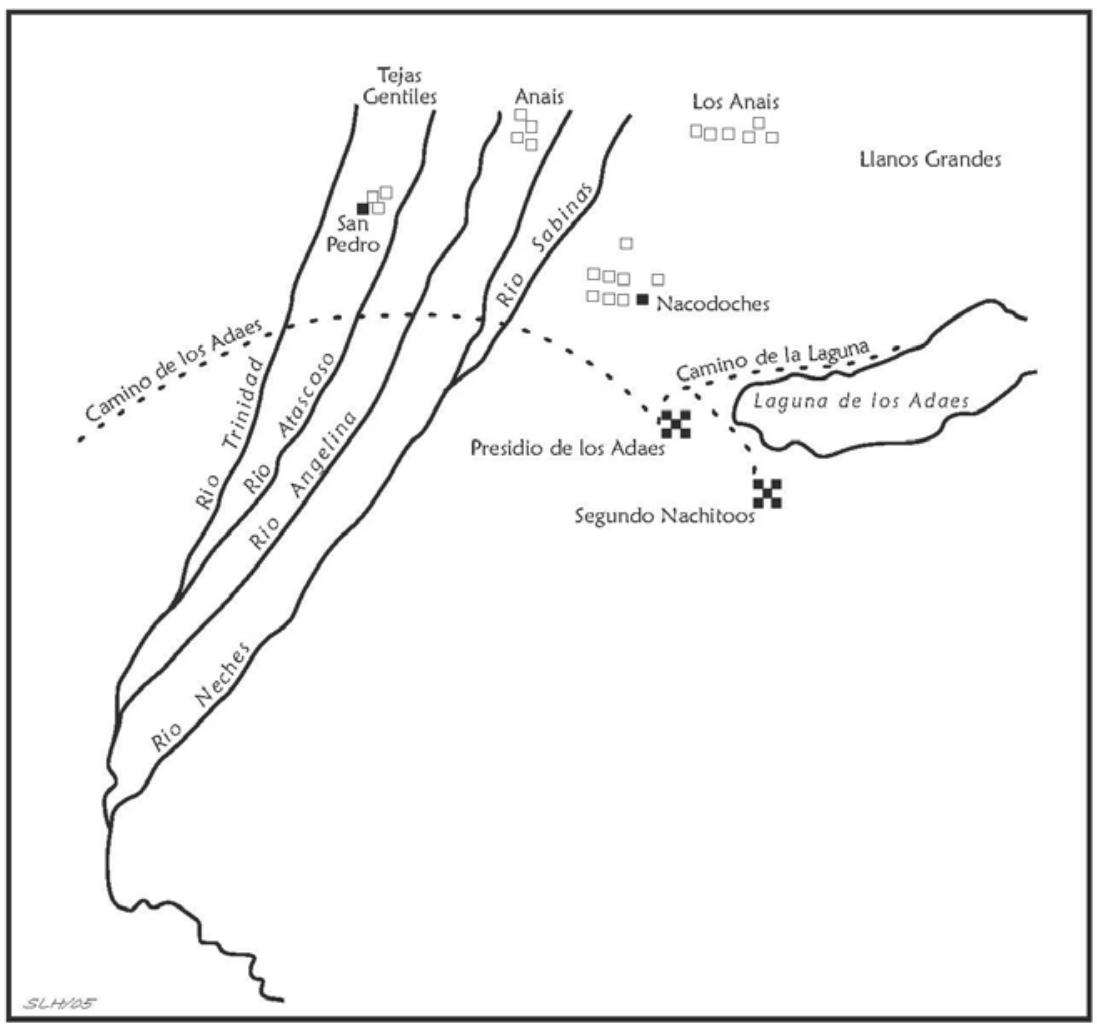

Figure 5. Redrawn version of 1757 map by Miranda, "Parte de la Provyncya De Texas" (Jackson 1999:Plate 35). 


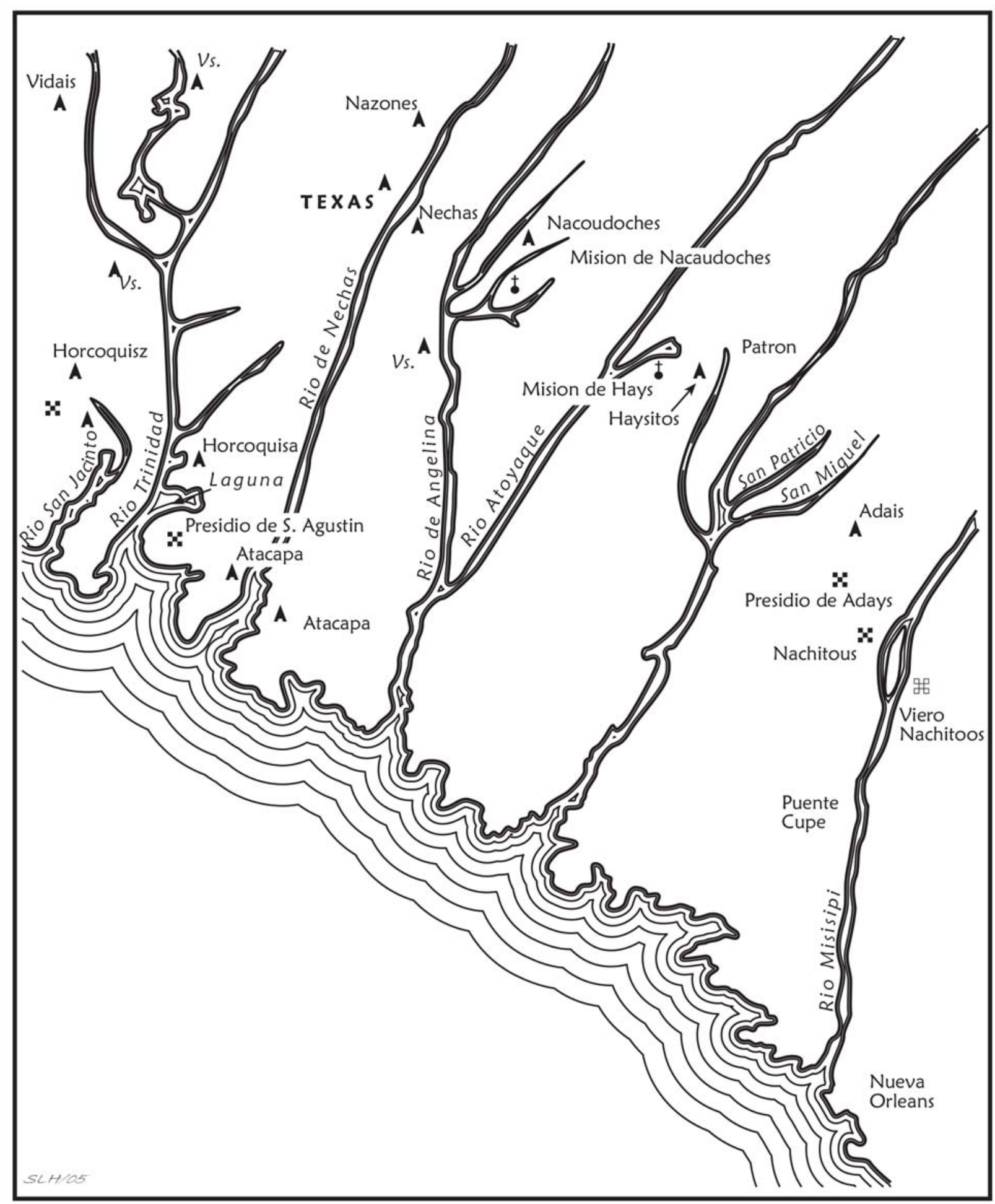

Figure 6. Redrawn version of 1771 map by Jose de Urrutia, "Map de toda Frontera de los dominios del rey en la America septentrional" (R. H. Jackson 2005:Map 10a). 
Table 1. East Texas Caddo Populations through the Colonial Era.

\begin{tabular}{|c|c|c|c|}
\hline Year & Source & Warriors* & Population \\
\hline \multicolumn{4}{|l|}{ Hasinai } \\
\hline 1699 & Pierre Talon & $600-700$ & $2400-2800$ \\
\hline 1716 & Ramon & - & $4000-5000$ \\
\hline 1721 & Aguayo & - & ca. 1378 \\
\hline 1779 & De Mezieres & 135 & 540 \\
\hline 1783 & Morfi & $380(?)$ & 1520 \\
\hline 1805 & Sibley & 200 & 800 \\
\hline $1818-20$ & Cincinnati Gazette & 150 & 650 \\
\hline 1820 & Padilla & - & 1450 \\
\hline 1828 & Teran & 23 & 92 \\
\hline 1828 & Berlandier & $30-40$ & $120-160$ \\
\hline 1834 & Almonte & - & 400 \\
\hline 1836 & Republic of Texas & - & 200 \\
\hline \multicolumn{4}{|l|}{ Hainai } \\
\hline 1783 & Morfi & 80 & 320 \\
\hline 1798 & Davenport & 60 & 240 \\
\hline 1809 & Salcedo & 60 & 240 \\
\hline 1828 & Berlandier & 10 & 40 \\
\hline \multicolumn{4}{|c|}{ Nabedache } \\
\hline 1779 & De Mezieres & 40 & 160 \\
\hline 1783 & Morfi & 40 & 160 \\
\hline 1798 & Davenport & 80 & 320 \\
\hline 1819 & Padilla & - & 500 \\
\hline 1828 & Teran & 15 & 60 \\
\hline 1828 & Berlandier & 80 & 400 \\
\hline \multicolumn{4}{|c|}{ Nacogdoche } \\
\hline 1783 & Morfi & 300 & 1200 \\
\hline 1798 & Davenport & $50 * *$ & 200 \\
\hline 1809 & Salcedo & 50 & 200 \\
\hline 1828 & Berlandier & 50 & 200 \\
\hline \multicolumn{4}{|l|}{ Nadaco } \\
\hline 1798 & Davenport & 100 & 400 \\
\hline 1809 & Salcedo & 100 & 400 \\
\hline 1828 & Teran/Sanchez & 29 & 116 \\
\hline 1828 & Berlandier & 30 & 150 \\
\hline \multicolumn{4}{|c|}{ Ais } \\
\hline 1716 & French traders & - & 320 \\
\hline 1779 & De Mezieres & 20 & 80 \\
\hline 1805 & Sibley & - & 25 \\
\hline $1818-20$ & Cincinnati Gazette & - & 50 \\
\hline 1820 & Padilla & - & 300 \\
\hline 1828 & Muckleroy/Teran & - & 640 \\
\hline 1828 & Berlandier & - & 300 \\
\hline
\end{tabular}

*one warrior is assumed to equate to four members of a family, but it is likely that this underestimates population sizes; some sources estimated five members to a family or five people per warrior. This table is based in part on the work of Swanton (1942:22-23).

**Nacogdoche and Ais groups 


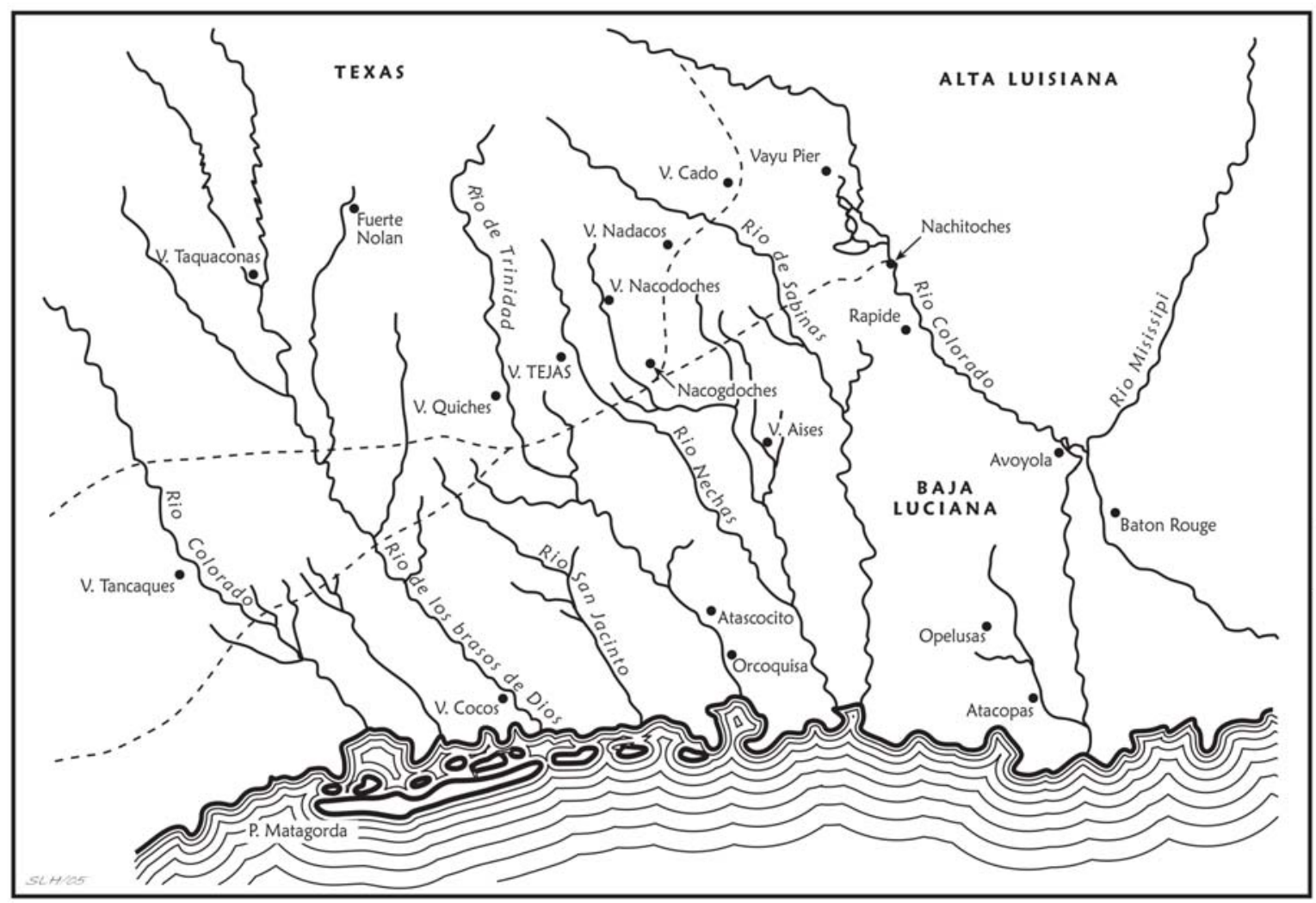

Figure 7. Redrawn version of Father Puelles 1801 map, "provincia de Texas en Luisiana."

As previously mentioned, Mission San Francisco de los Tejas (1690-1693) was also situated on San Pedro Creek (Figure 8), apparently astride the Camino de los Tejas (labeled "Ancienne route de Bexar a Nacogdoches"). This mission was established "in the middle" of the Nabedache Caddo village along San Pedro Creek (Bolton 1987:41), perhaps about 2 leagues (ca. 5.2 miles) from the Neches River; Weddle (2012:45) suggests it was actually 4 leagues from the mission site to the Neches River along El Camino de los Tejas.

\section{Known Caddo Archaeological Sites}

Archaeological evidence of Nabedache Caddo settlements that were occupied contemporaneously with the use of the Camino Real are known along San Pedro Creek, from near the headwaters to the confluence of San Pedro Creek and the Neches River (Erickson and Corbin 1996; Perttula 2004; Perttula and Nelson 2006, 2007a, 2007b; Perttula et al. 2011). These include 41HO6 (with a Spanish cannon or breech block discovered there, see Newell and Krieger 1949:13-14; Woldert 1935), 41HO64, 41HO65, 41HO66, and 41HO67 on the north side of San Pedro Creek (Newell and Krieger 1949; Perttula 2004; Perttula et al. 2011) and across from Mission Tejas State Park; the Plev Cutler site (41HO1) on a terrace at the confluence of the Neches River and San Pedro Creek; and 41HO91, 41HO122, Nabedache Blanco (41HO211), and Nabedache Azul (41HO214) within Mission Tejas State Park (Erickson and Corbin 1996; Perttula and Nelson 2006, 2007a, 2007b). There are also pre-A.D. 1680s Caddo sites known in the

San Pedro Creek valley, and they will also be discussed in this article along with the better known Historic Nabedache Caddo sites (see also Perttula 2015a).

\section{HO1, Plev Cutler}

Alex Krieger visited the Plev Cutler site in April 1944 during his reconnaissance of parts of the San Pedro Creek valley. He noted a few pieces of historic ceramic sherds (of European manufacture, but he 


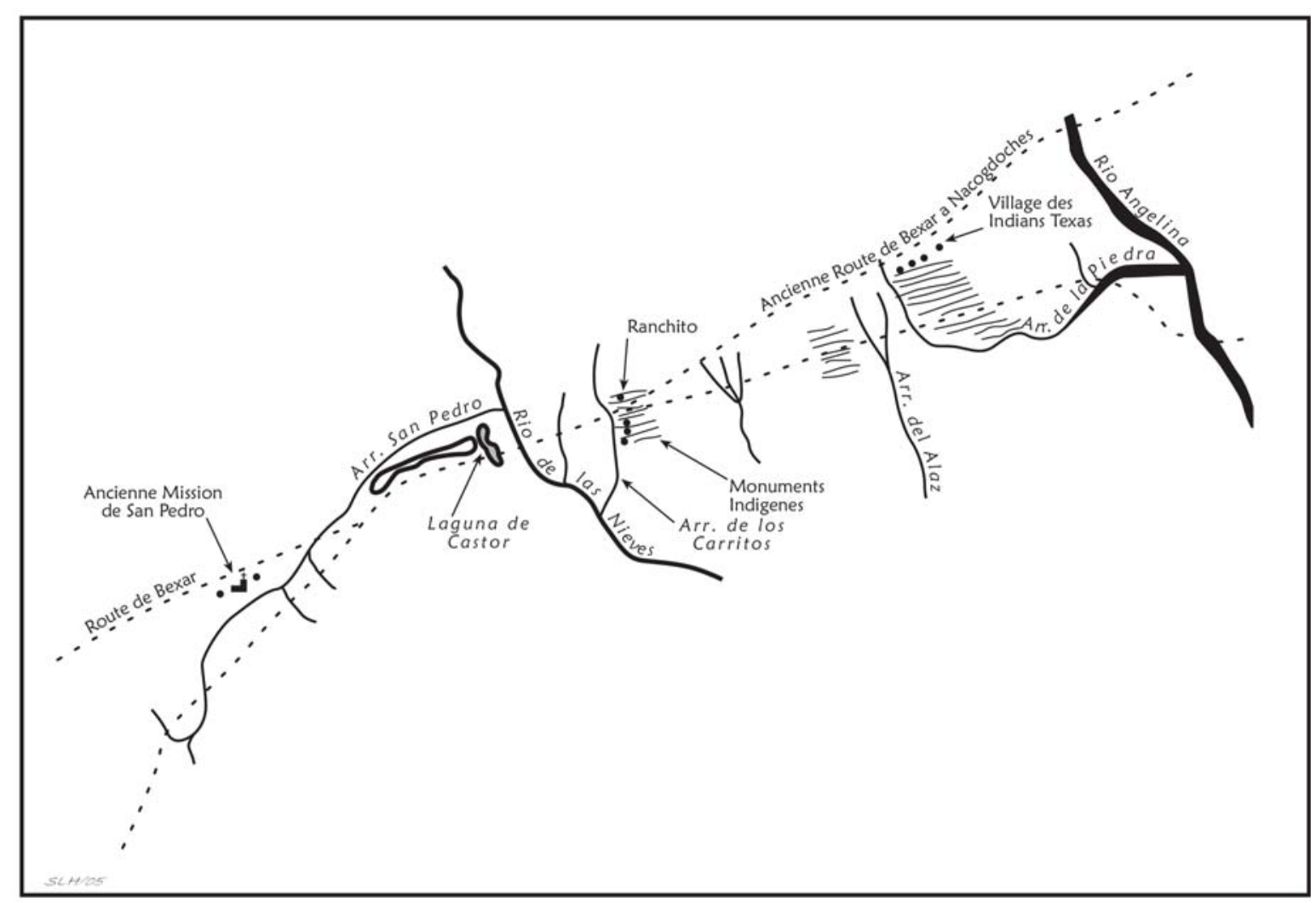

Figure 8. Redrawn version of ca. 1806 Juan Pedro Walker map of the area from San Pedro Creek on the west to the Angelina River (see McGraw et al. 1991:Figure 26).

did not specify what kind of ceramic sherds), fragments of mussel shell and animal bone, chipped stone tools, and ancestral Caddo sherds. These were found "in a plowed field to SE of point of land between Neches River \& San Pedro Creek. Crockery from under tree in clearing possibly used by picnickers or fishers" (April 15, 1944 letter on file at the Texas Archeological Research Laboratory, The University of Texas at Austin).

Edward B. Jelks formally recorded the site in June 1954 as part of the archaeological survey of the proposed Rockland Reservoir. He described the Plev Cutler site as being situated on the north bank of San Pedro Creek, on a low ridge in an old cultivated field. Jelks noted lithic debris, burned bone, and charcoal on the surface, but the landowner, Plev Cutler, told Jelks that he had found glass beads, lead bullets, gun parts, arrow points, and ceramic sherds here, and had amassed a collection from the site that included a number of glass beads and extensively modified gun barrels.

\section{HO6, George Moore \#1a}

The George Moore sites, \#1a-5, were identified by Alex D. Krieger in April 1944 during the course of a geological and archaeological reconnaissance of the lower valley of San Pedro Creek (Figure 9). Krieger noted that "on the north bank of San Pedro Creek, about 3 miles above (and west of) the confluence with the Neches, we located a large site with many glass beads and iron fragments. A small cannon, now at the San Jacinto Memorial near Houston, Texas, was plowed up here about 1933. This place is ... in a logical place for settlement and probably agreeable with Bolton's location of Nabedache" (Newell and Krieger 1949:13-14; see also Bolton 1908). In total, seven archaeological sites were located during the Krieger reconnaissance of plowed fields along San Pedro Creek, most of them on land owned by George A. Moore of Augusta, Texas: George A. Moore 1a (41HO6), 1b (41HO64), 1c (41HO65, with a catlinite pipe, see Perttula [2004:Figures 9-10]), 2 (41HO66), and 3 (41HO67), as well as Sites 4 
(41HO68) and 5 (41HO69) in different parts of the valley (Figure 9). There was also another site that was not recorded on the alluvial terrace north of $41 \mathrm{HO} 66$ and west of San Pedro Creek (Figure 9) because of the apparent low density of artifacts noted on the surface. Krieger saw one plain ceramic sherd, 5-6 pieces of lithic debris, and 5-6 small fragments of human bone, one of which was burned.

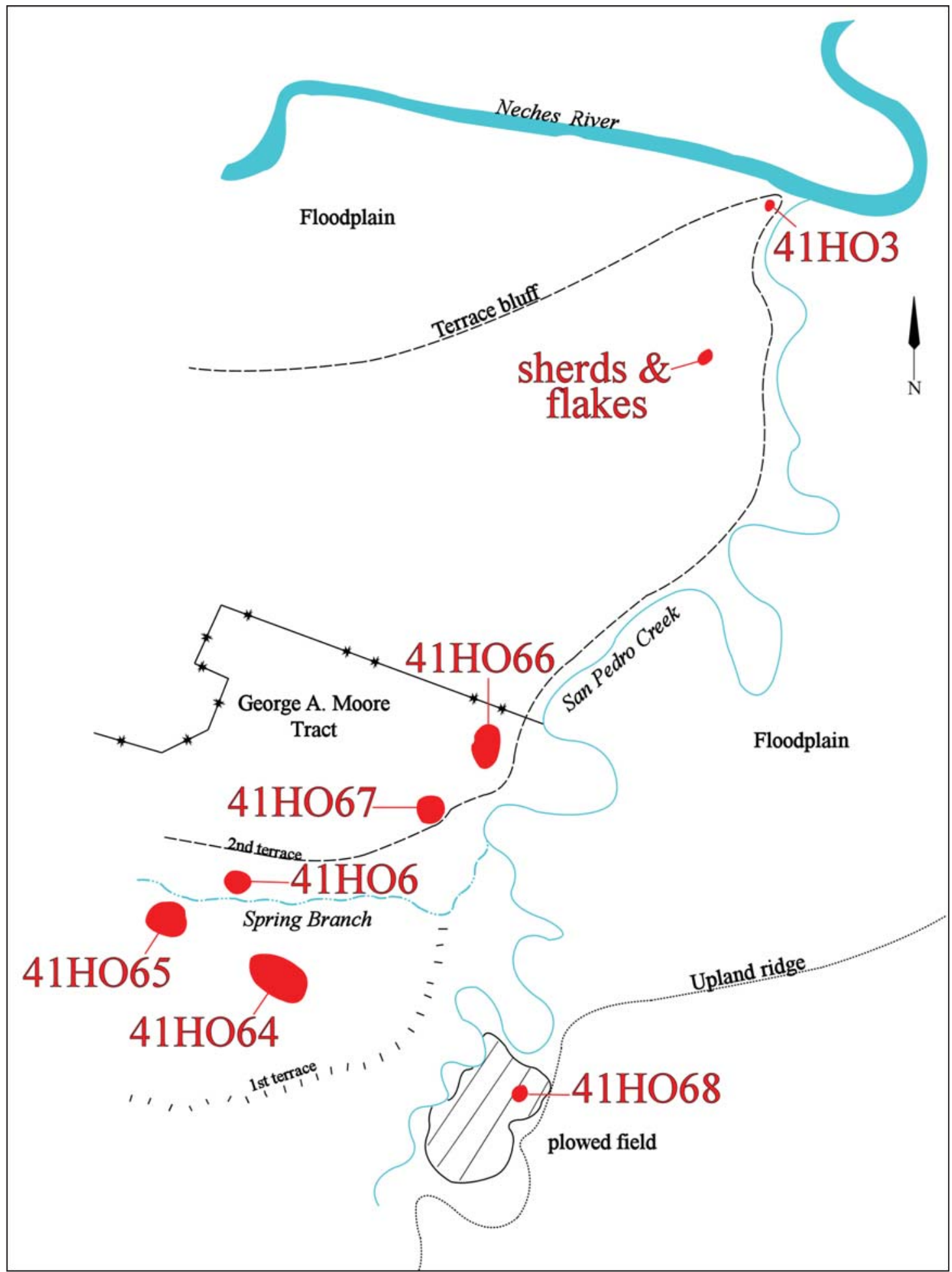

Figure 9. Redrawn from Krieger's 1944 map of the lower valley of San Pedro Creek showing the location of located archaeological sites. 
The site with the reputed cannon-41HO6- were said by Mr. Moore to have come from a plowed level field north of a small draw (a spring-fed tributary to San Pedro Creek) (see Figure 9); Woldert (1935) reported that the cannon was found at a depth of ca. $25 \mathrm{~cm}$ while Mr. Moore was plowing the field. Weddle (2012:47) suggests that this object is actually "the breech block of a small-bore artillery piece, such as a swivel gun." Whether this breech block, at the San Jacinto Museum of History, is the same piece of artillery mentioned by Moore to Woldert or Krieger is an open debate and probably not easily resolved. The catalogue information for the breech block at the San Jacinto Museum of History indicates that it was found by George A. Moore in 1923 (Weddle 2012:46); Newell and Krieger (1949:14) have the discovery about 1933, and in Krieger's 1944 letter about the survey, he indicated the cannon had been plowed up by George Moore in 1940 .

\section{HO64, George Moore \#1b}

Not far to the south of the George Moore \#1a site, but south of the draw (see Figure 9) and on the first alluvial terrace or alluvial fan, Moore had plowed up 7-8 Caddo Indian burials from a cemetery on a low rise that had many glass beads found in association. He had also found several hundred glass beads, a ceramic pipe fragment, a Perdiz arrow point, and fragments of human remains during plowing, along with a number of large basally-notched Calf Creek series dart points.

Perttula (2004) has discussed some of the archaeological findings from the George Moore \#1b site, and the nearby George Moore \#1c site, based on the documentation of the Jackie Lively (and George A. Moore) collection from these sites. An assemblage of 7646 beads has been documented from 41HO64 (see Perttula 2004:93 and Table 1), and these are consistent with ca. A.D. 1690-1730 beads found in other East Texas Caddo sites. Lively had "dug up at least one human skeleton which had large quantities of blue glass trade beads in association. Lively also has collected metal artifacts from the site." More recent discussions with Erwin Roemer (July 2004 e-mail to the author) indicate that Mr. Lively had probably dug up three or four burials in one location at the George Moore \#1b site.

The more than 7640 glass beads in the collections from the George Moore \#1b site is one of the larger collections from a Caddo site in the region; some of the beads are apparently from Mr. Moore's 1940s collection, and the remainder are from the Lively digging at the site. However, there is no detailed information available on which specific beads were found by either individual; a 1944 photograph in Alex Krieger's correspondence indicates that Mr. Moore had several hundred beads of the same size and colors as those now in the Lively collection.

According to what Mr. Lively told Erwin Roemer in 1985, the beads were found in close association with the Nabedache Caddo burials, apparently near the skulls of several. They may have been in loops or strands that were arranged or woven into the hair of the deceased individuals (Roemer, July 2004 e-mail to the author). The strands of beads that are illustrated herein were strung by Mr. Lively, and do not represents the kinds or lengths of beads that may have strung together as burial accompaniments by the Caddo some 300 years ago.

There are a number of glass bead classification systems in use in North America, including Harris and Harris (1967), Kidd and Kidd (1970), Brain (1979), Karklins (1985), DeVore (1992), and Ross (2000). All have their merits and pitfalls, and Karklins (1985:86-87) discusses these as part of his description and classification of glass beads. I have relied principally on the classification scheme developed over the years by Kidd and Kidd (1970), as it is the most comprehensive, particularly with respect to the typology of drawn beads (Karklins 1985:86), and it is of considerable value in inter-site comparisons because the system is widely used to classify bead assemblages throughout North America, Europe, and other parts of the world.

All of the glass beads from the George Moore \#1b site are drawn beads (Kidd and Kidd 1970:48-49), either tubular or round in shape (Figure 10). The beads range from small to large in size; small beads are 
less than $4 \mathrm{~mm}$ in length and diameter, compared to $4-6 \mathrm{~mm}$ for medium-sized beads, and greater than 6-10 $\mathrm{mm}$ for large beads (Kidd and Kidd 1970). The large beads comprise only 4.2 percent of the beads in the Lively collection from the site. Only a few of the beads are surface decorated, although many of them are compound or multi-layered beads, including more than 350 Cornaline d'Aleppo beads (Figure 11).

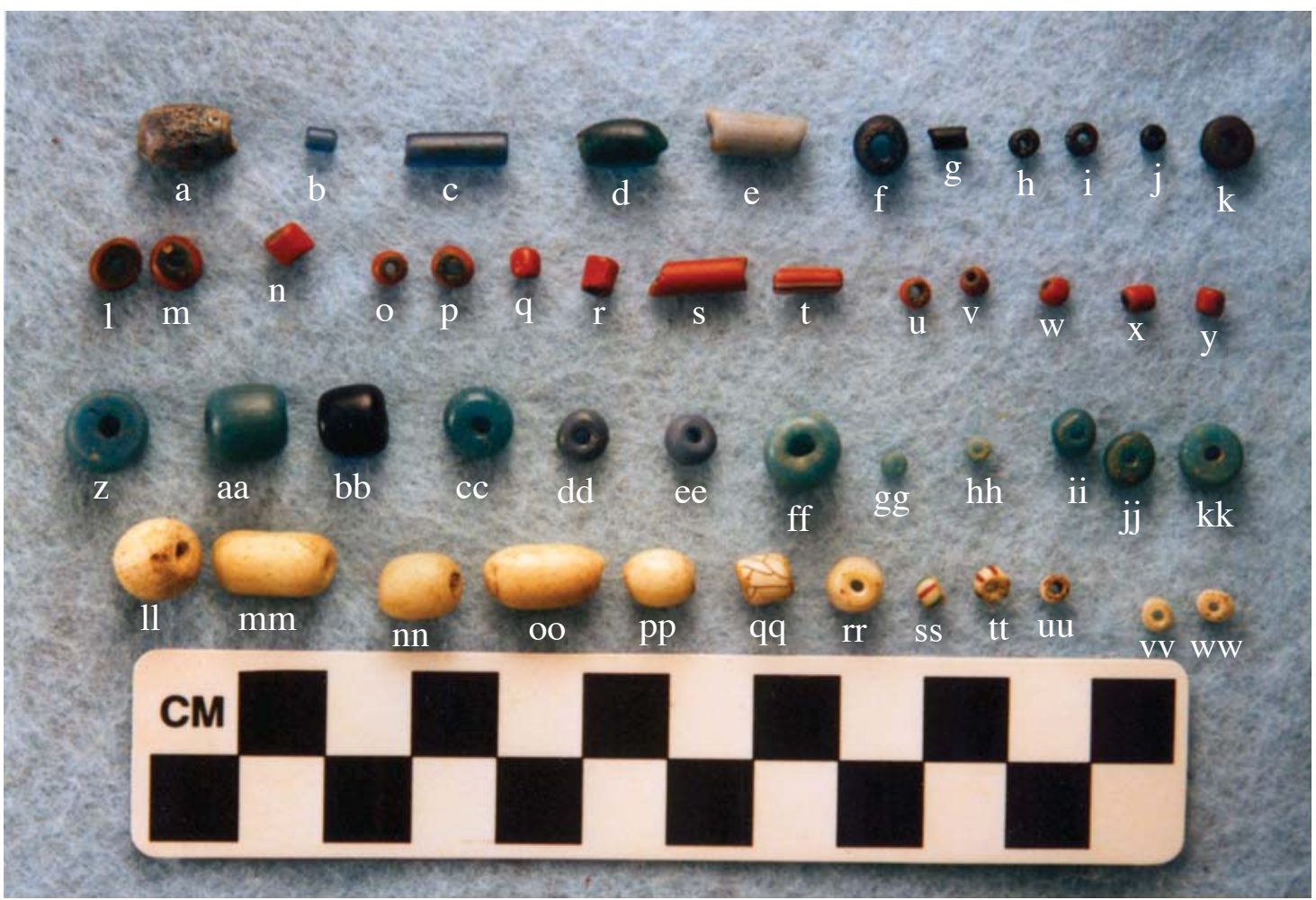

Figure 10. Glass bead varieties from the George Moore \#1b site.

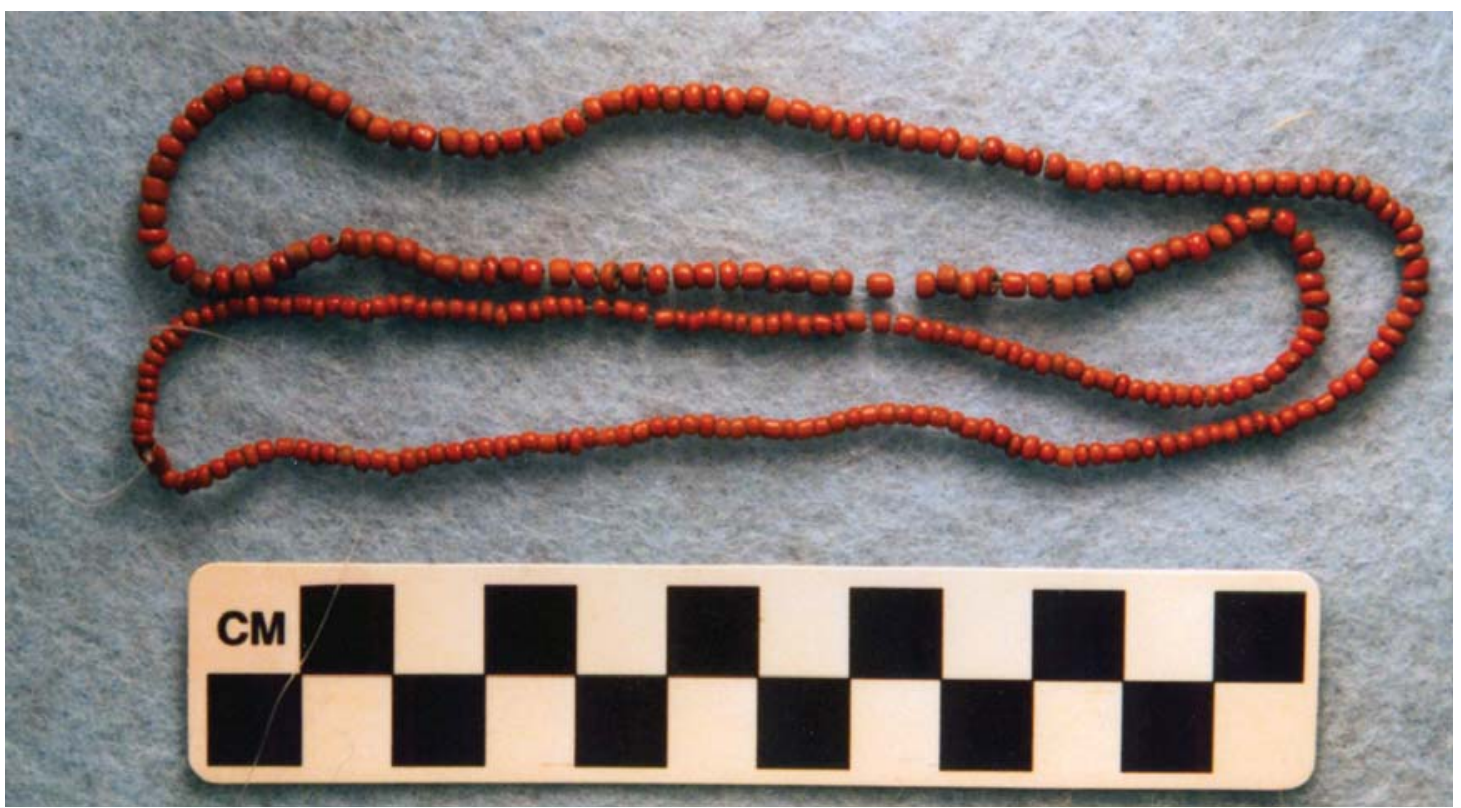

Figure 11. Cornaline d'Aleppo beads. 
The beads fall into four classes of drawn beads (see Kidd and Kidd 1970:50,53) in the assemblage, with a number of different colors, shapes, and types of glass (i.e., whether the glass is opaque, clear, or translucent):

Class I, tubular-shaped with simple or monochrome bodies;

Class II, non-tubular or rounded with simple or monochrome bodies;

Class III, tubular-shaped, with compound or multi-layered bodies;

Class IV, non-tubular or rounded with compound or multi-layered bodies.

All told, there are 22 varieties of glass beads in the collections from the George Moore \#1b site (Table 2; see also Figure 10), which suggests a low diversity in the range of beads used by the Caddo, considering that more than 100,000 varieties of glass beads have been manufactured to date across the world (Karklins 1985:87). By way of comparison, the very large bead assemblage $(n=186,200)$ from the Tunica Treasure has 96 varieties of glass beads (Brain 1979).

Table 2. Glass bead varieties from the George Moore \#1b site (41HO64).

\begin{tabular}{|c|c|c|c|c|}
\hline $\begin{array}{l}\text { Variety (after } \\
\text { Kidd and Kidd } \\
1970 \text { ) }\end{array}$ & Small & Medium & Large & $\mathrm{N}$ \\
\hline Ia2 & 1 & - & - & 1 \\
\hline Ia5 & - & - & 1 & 1 \\
\hline Ia16 & - & - & 1 & 1 \\
\hline Ia19 & - & 1 & - & 1 \\
\hline Ia 20 & - & - & 1 & 1 \\
\hline IIa7 & 10 & 1 & - & 11 \\
\hline IIa13 & 1172 & 149 & 2 & 1323 \\
\hline IIa15 & - & - & 3 & 3 \\
\hline IIa36 & 27 & 17 & 2 & 46 \\
\hline IIa38 & - & - & 4 & 4 \\
\hline IIa39 & 3582 & 1891 & 300 & $5753^{*}$ \\
\hline IIa 40 & - & 7 & - & 7 \\
\hline IIa43 & 5 & - & 1 & 6 \\
\hline IIa54 & - & - & 1 & 1 \\
\hline IIa55 & 84 & 15 & 2 & $101 * *$ \\
\hline IIb'5 & 1 & - & - & 1 \\
\hline IIb20 & 1 & - & - & 1 \\
\hline IIb28 & - & - & 2 & 2 \\
\hline IIb33/34 & 1 & - & - & 1 \\
\hline IIIa1 & 1 & - & - & 1 \\
\hline IIIbb1 & 1 & - & - & 1 \\
\hline IVa2 & 333 & 18 & 2 & 353 \\
\hline Totals & 5225 & 2100 & 321 & 7646 \\
\hline
\end{tabular}

*149 are medium to large barrel-shaped beads; ** five are small barrel-shaped beads 
Two bead varieties comprise more than 92 percent of the sample: rounded beads that are either aqua blue (IIa39) or an opaque white (IIa13) (Figures 12-15) (see Table 1). As previously mentioned, another relatively important bead variety is the Cornaline d'Aleppo bead (IVa2) (see Figure 11); they represent almost 5 percent of the beads from the site.

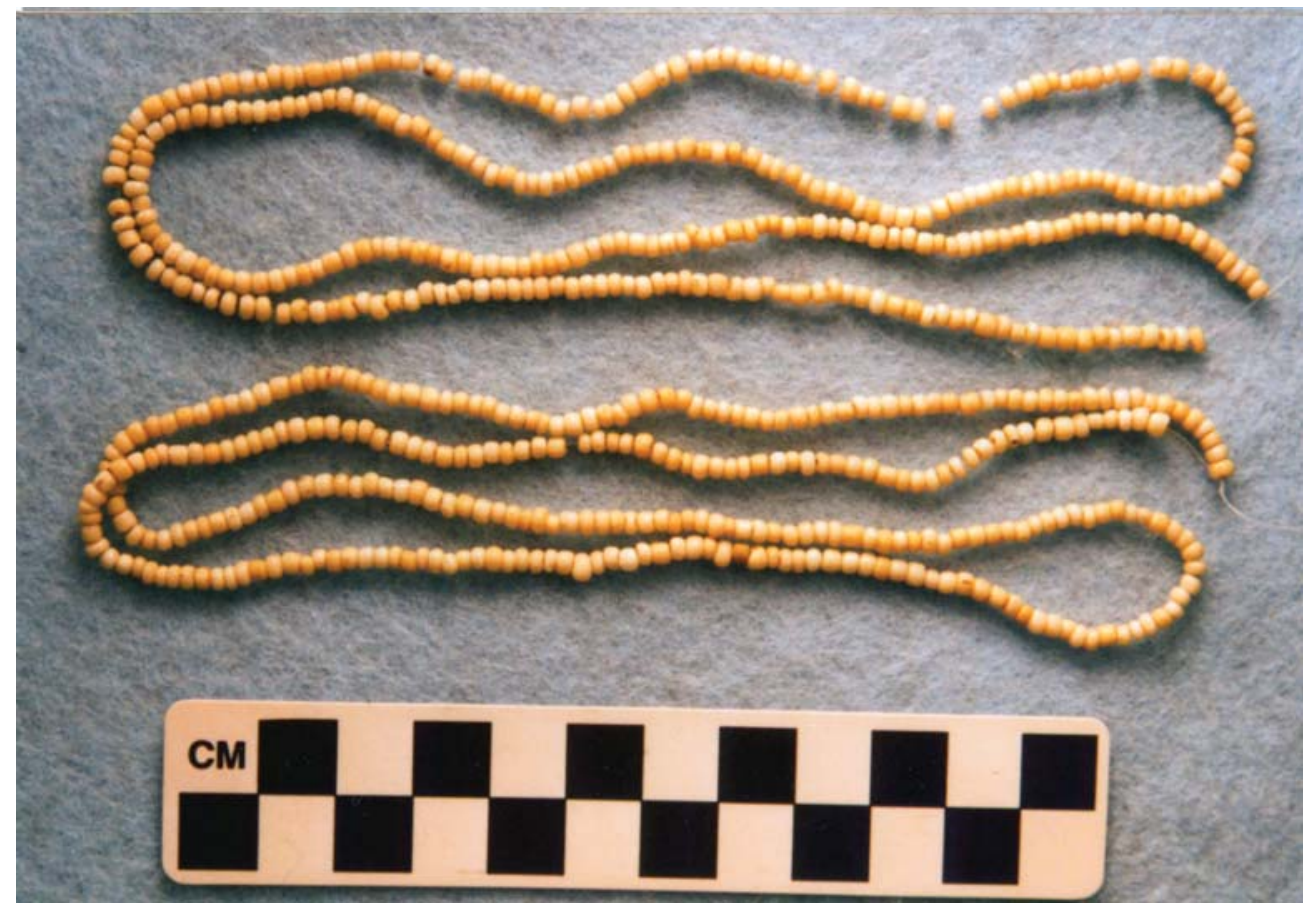

Figure 12. White drawn beads.

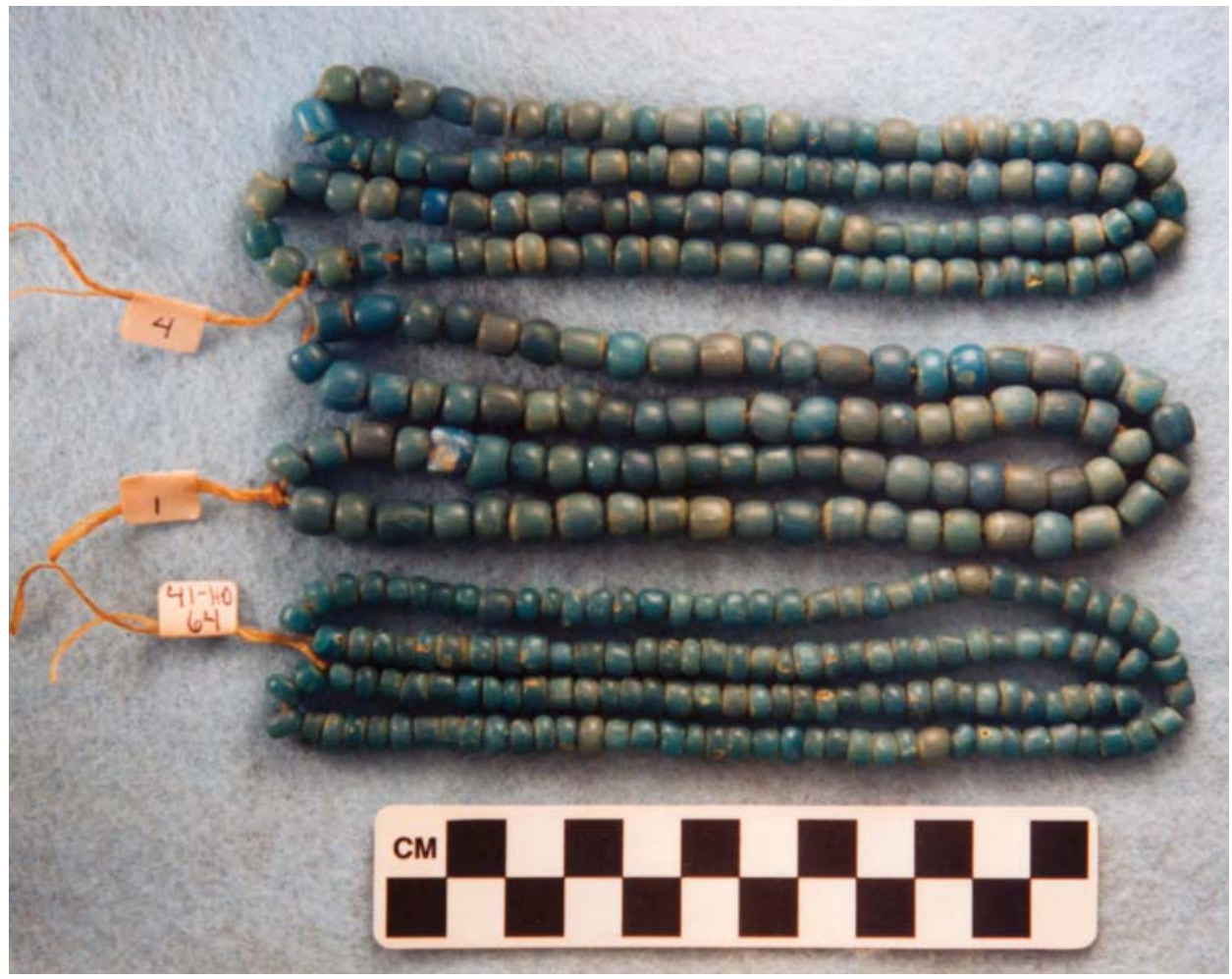

Figure 13. Aqua blue drawn beads. 


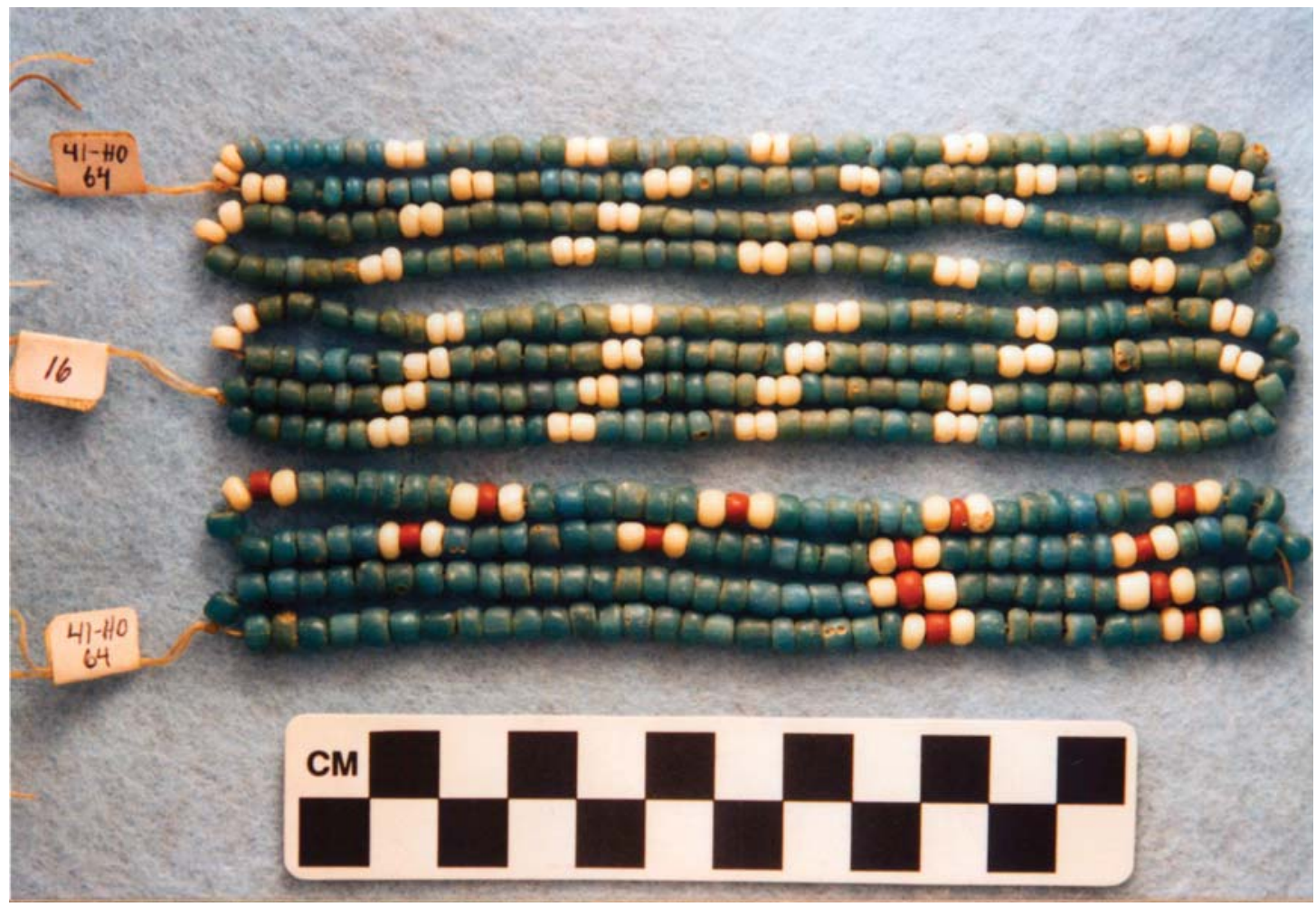

Figure 14. Strands of white, aqua blue, and Cornaline d'Aleppo beads.

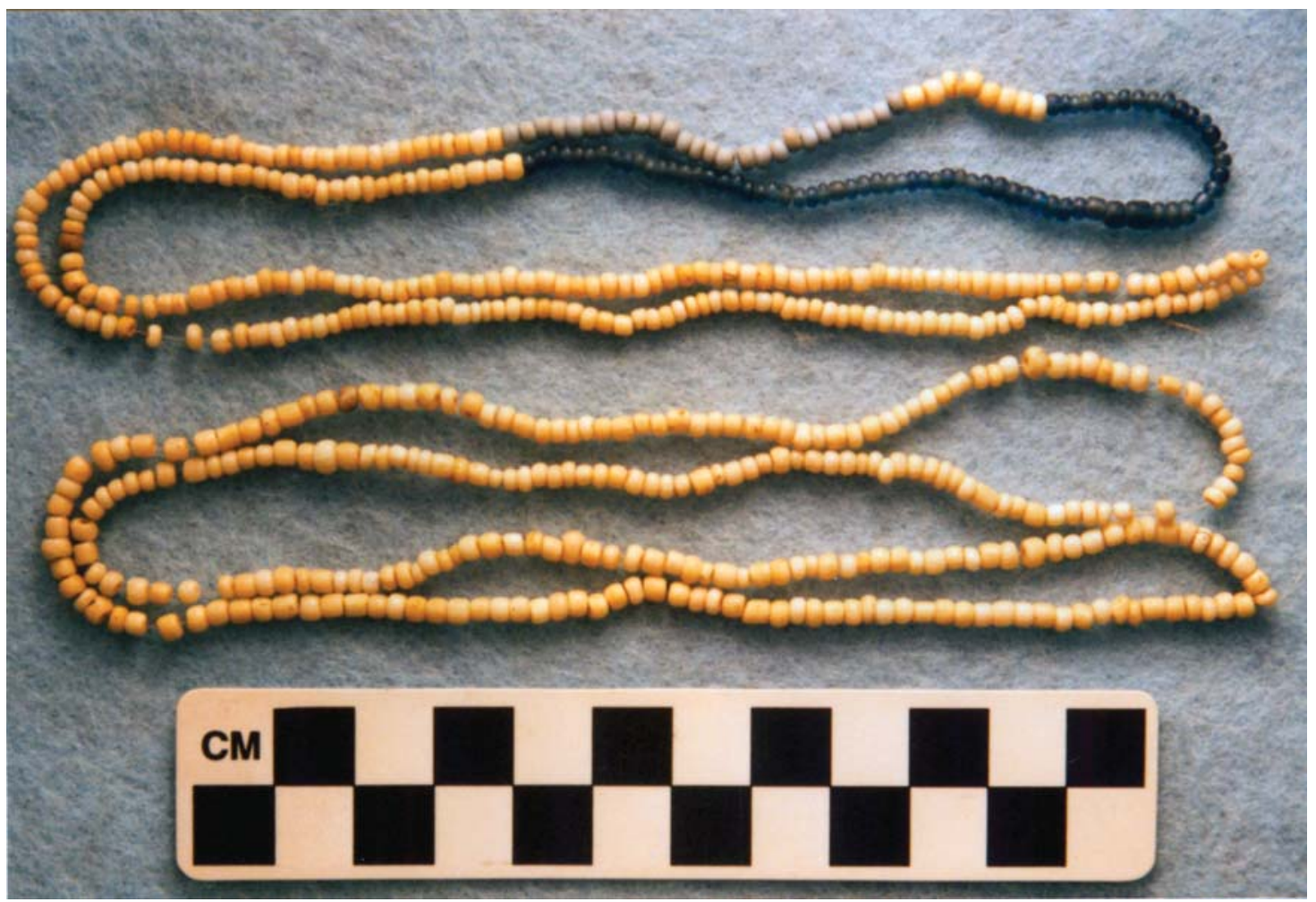

Figure 15. Strands of white and blue drawn beads. 
Only five Class I beads, mostly medium to large-sized examples, are in the collection. They are black (see Figure 10g), white (see Figure 10e), an opaque blue, a clear navy blue (see Figure 10c), and clear dark navy blue colors.

The Class IIa beads are the predominant bead varieties at the George Moore \#1b site, accounting for about 95 percent of the beads in the collection (see Table 2). The principal colors are an aqua blue (IIa39) (see Figure 10z-aa, cc-kk and Figures 13-14), in a range of sizes; mostly small opaque white (IIa13) (see Figure 10vv-ww and Figures 12, 14, and 15) beads, but also including a few medium to larger bead sizes (see Figure 1011-nn, qq-rr), as well as an oval-shaped white bead (IIa15, see Figure 10oo-pp); and a clear navy blue (IIa55, see Figure 15) bead. The few remaining Class IIa beads are aqua blue (IIa36), ultramarine blue (IIa54, see Figure 10a), a translucent bright blue (IIa43), an opaque blue (IIa40), and an oval-shaped aqua blue (IIa38, see Figure 10d), along with a few black (IIa7, see Figure 10bb) beads (see Table 2).

A distinctive but very rare group of the Class II drawn beads includes five Class IIb examples (see Table 2), all white in color. One example (IIb'5) has six red stripes on it (see Figure 10tt), while another has only three stripes (IIb20). Another larger white bead has three sets of navy blue stripes (IIb28), and the last (IIb33/34) has both red and green stripes (see Figure 10ss).

The Cornaline d'Aleppo beads are the only Class IV beads from the site (see Table 2) (see Figure 101-r, u-y and Figure 11), and they are mostly small in size and rounded, with a exterior glass layer that is red and an interior glass core that is light gray in color. The one Class IIIa1 bead (see Figure 10s) is a tubular variety of Cornaline d'Aleppo, with a red outer color and a black core. The only other Class III bead (see Figure 10t) has a red exterior, a black core, and three white and black stripes on the exterior glass layer.

The Cornaline d'Aleppo beads are usually quite abundant in $18^{\text {th }}$ century sites in French Louisiana and Spanish Texas (e.g., Brain 1979, 1988; Harris and Harris 1967). They are rounded drawn beads of compound construction, with an outer brick red or redwood (10.0R 4/8) layer and an inner layer of several different colors, including black, light gray, green, or blue (Kidd and Kidd 1970:Table 5). The tubular-shaped variety is a very common find on French and Spanish colonial-era sites in Texas and Louisiana (see Gregory and Webb 1965; Harris and Harris 1967; Brain 1979). Mitchem (1993:409-410) had noted from a late $17^{\text {th }}$ century Spanish village context at the Apalachee town and mission of San Luis de Talimali in Florida that Cornaline d'Aleppo beads were reserved for use by the Spanish rather than as trade goods for the Indians, but this does not appear to be the case at the George Moore \#1b site from the little known about where the beads were found.

Beads were mentioned by Joutel on numerous occasions in his 1684-1687 journal, and these "trinkets" were apparently traded frequently to the Nabedache Caddo by the La Salle expedition members, including Joutel (Foster 1998:197, 204, 205, 208-209, 213, 220). The Nabedache Caddo apparently preferred the color blue (see Bolton 1987:133-134) for fabrics, and apparently also for the beads they used for ornamentation of their clothes and in necklaces. Glass beads, in general, however, are rare on Neches River Caddo sites, though, and include only a few large blue beads from Allen phase sites (Cole 1975:Table 19), including one site (41HO91) on San Pedro Creek (Erickson and Corbin 1996) in the specific vicinity of the Nabedache Caddo village visited by the La Salle Expedition, but on the east side of the creek, the Nabedache Azul (41HO214) and Nabedache Blanco (41HO211) sites (see below), as well as the George Moore \#1b site, where there are many large blue beads.

Are the beads from the site from late $17^{\text {th }}$ century French and Spanish traders and soldiers, or are they from a period after the abandonment of the Mission San Francisco de los Tejas? One way to look at the chronological distinctiveness of the beads at the site and in the region is to examine the general sequence of bead types on late $17^{\text {th }}$ century to $19^{\text {th }}$ century sites in Texas and Northwest Louisiana. This sequence 
is based on comparative data on sites with large bead assemblages where the beads were classified using the Harris and Harris (1967) classification system (Table 3), and as such provides a way to determine how the George Moore \#1b site bead assemblage compares with regional trends in bead use on Native American sites in the region, and how old the beads are. For this purpose, I have grouped the more than 180 bead types in the Harris and Harris (1967:139-155) scheme into eight broad groups based primarily on bead size, decoration, and method of manufacture (i.e., drawn or wire-wound beads). In the case of bead Groups VII and VIII (Table 3), these represent a number of bead types that Harris and Harris (1967:157) suggest appeared in the bead trade during two specific temporal intervals (1767-1780 and 1780-1820); none of them are present at the site.

Table 3. Chronological sequence of bead types from Texas and Northwest Louisiana sites, using the Harris and Harris (1967) bead classification system.

\begin{tabular}{|c|c|c|c|c|c|c|c|c|c|}
\hline \multirow[t]{2}{*}{ Sites } & \multicolumn{8}{|c|}{ Bead Groups } & \multirow[b]{2}{*}{ Totals } \\
\hline & $\mathrm{I}^{*}$ & II & III & IV & $\mathrm{V}$ & VI & VII & VIII & \\
\hline Clements, pre-1700 & $97.8^{* *}$ & - & - & 2.2 & - & - & - & - & 45 \\
\hline $\begin{array}{l}\text { Atlanta State Park, } \\
\text { pre-1700 }\end{array}$ & 72 & - & - & 28 & + & - & - & - & 1841 \\
\hline Womack, 1700-1730 & 40 & 3 & 0.6 & 56 & 0.5 & - & - & - & 2123 \\
\hline Deshazo, 1686-1714 & 25 & + & - & 66 & 8.4 & - & - & - & 4646 \\
\hline $\begin{array}{l}\text { Roseborough Lake, } \\
1720-1780\end{array}$ & 8 & 0.7 & 0.1 & 72 & 4.5 & 2.2 & 4 & - & 2958 \\
\hline Gilbert, 1740-1767 & 7 & + & 0.1 & 71 & 11.3 & 3.6 & - & - & 3453 \\
\hline Vinson, 1760-1790 & 1.2 & - & 0.1 & 66 & 19 & 9.2 & 0.6 & 1.2 & 2785 \\
\hline Walton, ?-1820 & 0.1 & - & - & 82 & 6.2 & 0.2 & 10.8 & - & 2392 \\
\hline Stansbury, ?-1840 & + & - & - & 91 & + & - & - & - & 2499 \\
\hline $\begin{array}{l}\text { Canyon Creek, } \\
1800-1850\end{array}$ & 0.8 & - & 2.7 & 92.5 & 4.0 & - & - & - & 2499 \\
\hline
\end{tabular}

*Group I =large-medium-sized (No. 1-18); Group II =large-striped, No. 20-39; Group III =large wound and faceted, No. 40-43, 52-54; Group IV =small seed/drawn, No. 44-50; Group V =Cornaline d'Aleppo, No. 51, 55, 57, 59, 67-68, 86, 99; Group VI= small drawn beads, No. 79-84; Group VII=1767-1780 varieties, No. 64-65, 98, 101-104, 106-108, 115, 118, 128, 137-138, 155; Group VIII=1780-1820 varieties, No. 95, 100, 109, $111-114,116-117,119-120,122,124,129,132$

** Percentage $;+=$ trace

Sources: Creel 1982; Harris and Harris 1967; Harris et al. 1965, 1980; Jelks 1967; Lewis 1987; Miroir et al. 1973; Shafer et al. 1994; Smith et al. 1993; Stephenson 1970; Story 1985

The sites can be readily separated into three different and chronologically distinctive bead assemblages: those that date before 1700; a second group that dates from ca. 1700-1767; and a third that dates from ca. 1760-1850 (see Table 3). The first group is dominated by medium-sized to large white, blue, and black beads of simple construction, with less than 30 percent of the beads being small drawn beads of the same colors.

The 1700-1760 beads have more small drawn beads than do the pre-1700 sites, ranging from 5672 percent, along with significant numbers of medium to large drawn beads (Group I) and drawn and tubular-shaped Cornaline d'Aleppo beads (Group V). Cornaline d'Aleppo beads in particular seem characteristic of many $18^{\text {th }}$ century Texas Caddo and Wichita sites, more so than many other historic Native American sites in the southeastern U.S. Large striped and wound beads make their first appearance in the 1700-1760 sites - as is generally the case for colonial French Louisiana sites in the Southeast (Smith 2002) - with the exception of earlier $17^{\text {th }}$ century striped beads from a few sites that appear to be of Spanish origin (see Smith 1983, 1987, 1990; Ricklis 1994). 
There is a clear temporal trend in the bead assemblage data of the small drawn "garmet" or "embroidery" beads (Group IV) replacing the larger and heavier "necklace" beads (Groups I-III) by ca. 1750. This trend or shift in bead size has been previously noted by Gregory (1973) and Hunter (1990) in Texas and Louisiana $18^{\text {th }}$ century aboriginal sites, and this overall bead size trend appears to culminate in the mid- $19^{\text {th }}$ century in Texas and Northwest Louisiana sites, along with the appearance after 1800 of large faceted beads (see Table 2). By the early $19^{\text {th }}$ century, small drawn beads comprised more than 90-95 percent of the beads from this group of sites, and the larger beads were primarily faceted (see Table 3 ).

The George Moore \#1 site glass beads include approximately 32 percent that are medium to largesized drawn beads (bead Group I), only a trace of Group II striped beads, 4.6 percent Cornaline d'Aleppo beads (bead Group V), with the remainder (63 percent) being Group IV small drawn beads of various colors (see Table 1). In the Table 3 bead seriation, this bead assemblage would fall readily between the Deshazo (Creel 1982) and Womack (Harris et al. 1965) site beads; those two sites were occupied by different Caddo groups between ca. 1686-1730, and this 40+ year period may be a reasonable approximation of either when Caddo groups were living at the site, or the period of principal trading activities between the Caddo and French traders. Nevertheless, the ca. 1686-1730 temporal estimate is strong evidence that this site on San Pedro Creek was occupied by the Nabedache Caddo for at least 1-2 generations during the late $17^{\text {th }}$ and early $18^{\text {th }}$ centuries.

The character of the beads at the George Moore \#1b site was likely shaped by European views of what sorts of glass beads would be suitable for trading purposes, as well as what sorts of beads may have been available for trade. The most notable characteristic of the glass beads from the site is how they are dominated by medium to large translucent blue drawn beads, small and medium-sized opaque white drawn beads, and rounded Cornaline d'Aleppo beads; less than 0.1 percent of the beads are small opaque black beads, and a little more than 1 percent are small clear or translucent drawn black beads. There are only a very few decorated or polychrome beads, no solid red beads, very few tubular beads of any size, and no wire beads. Smith $(1983,1987)$ has noted the same prevalence of small monochrome beads, primarily blue in color, in 1630-1670 sites in the Southeast, with very few polychrome beads or red beads. Blue, white, and black beads of either simple or compound construction are the principal bead types at a wide range of late $17^{\text {th }}$ to mid- $18^{\text {th }}$ century sites in Pennsylvania and New York; Illinois, Michigan, and Wisconsin; Louisiana, Mississippi, and George; as well as Texas, and Cornaline d'Aleppo beads are most common in Texas sites dating to the mid- $18^{\text {th }}$ century. Large wire beads make their appearance in the Northeast and Southeast after ca. 1687 (see Smith 2002; Wray 1983).

\section{Gun parts and ammunition}

The gun parts and ammunition are the only metal artifacts in the collection from 41HO64. The one gun part is an iron gun cock (Figure 16b), with a comb width $(9.4 \mathrm{~mm}$ ) of pistol-size (see Jelks 1967:Figures 27 and 31h). The gun cock has a narrow tapered comb upon which a gunflint would sit; beveled basal edges; and a flat face; its overall height is $75 \mathrm{~mm}$. There is a squarish hole in the gun cock base, and that hole held a screw to mount the gun cock to the lock plate of the gun.

The ammunition includes two pieces of lead shot (Figure 17a-b) and two lead balls. The lead shot had diameters ranging from 3.3-3.9 mm. They are spheroid in shape, with one flattened side, and with a dimple. Hamilton (1979:208) suggests lead shot pieces like those from the site were made by the French between ca. 1665-1769.

The lead balls are irregular and flattened (see Figure 17c-d), suggested they had been fired, and one (see Figure 17c) has evidence of sprue cutting on one edge. The other (see Figure 17d) is rounded and lipped. Diameters of the two lead balls range from 16.3-21.0 $\mathrm{mm}$. 


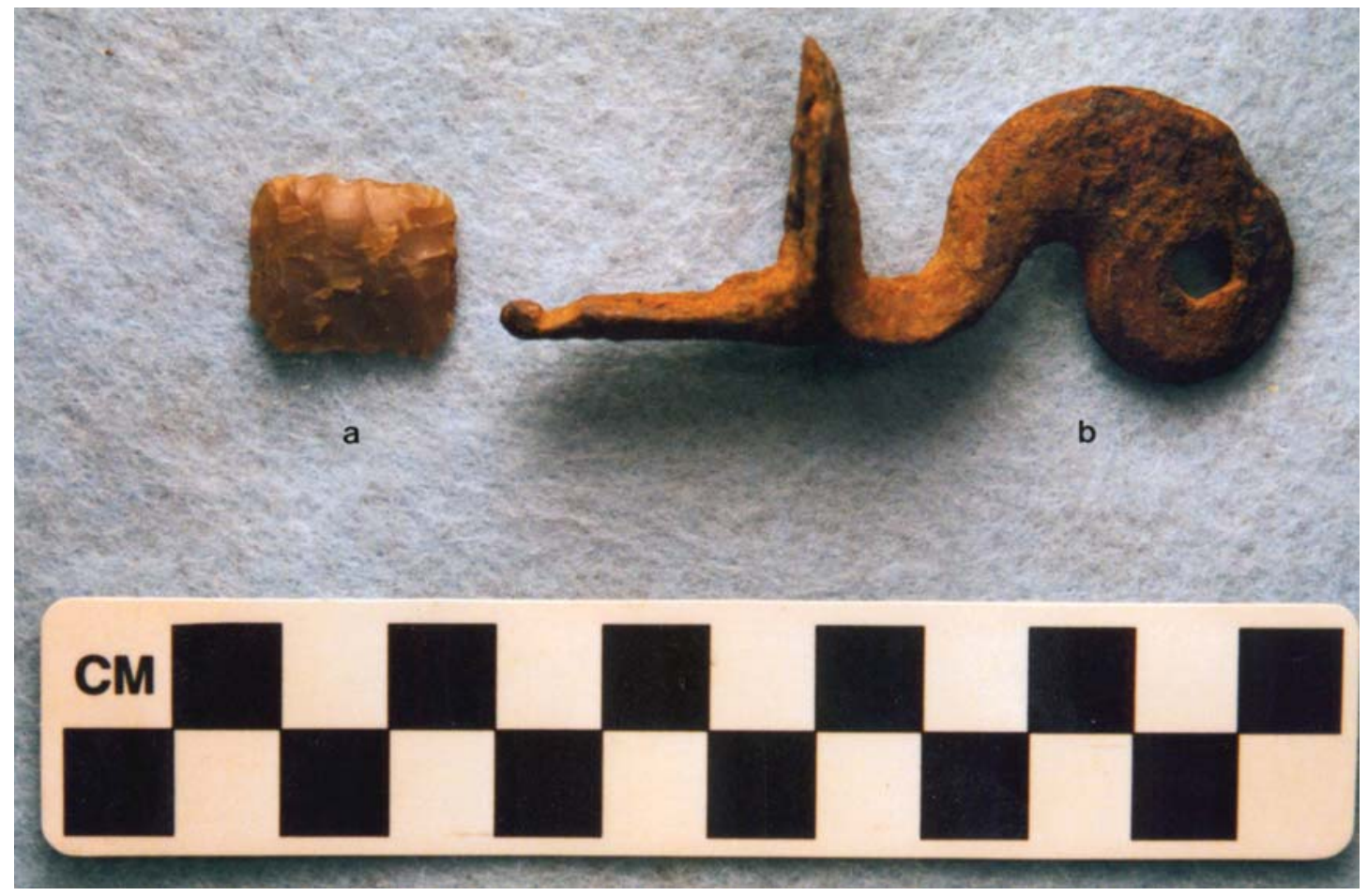

Figure 16. Gun cock and native-made gunflint.

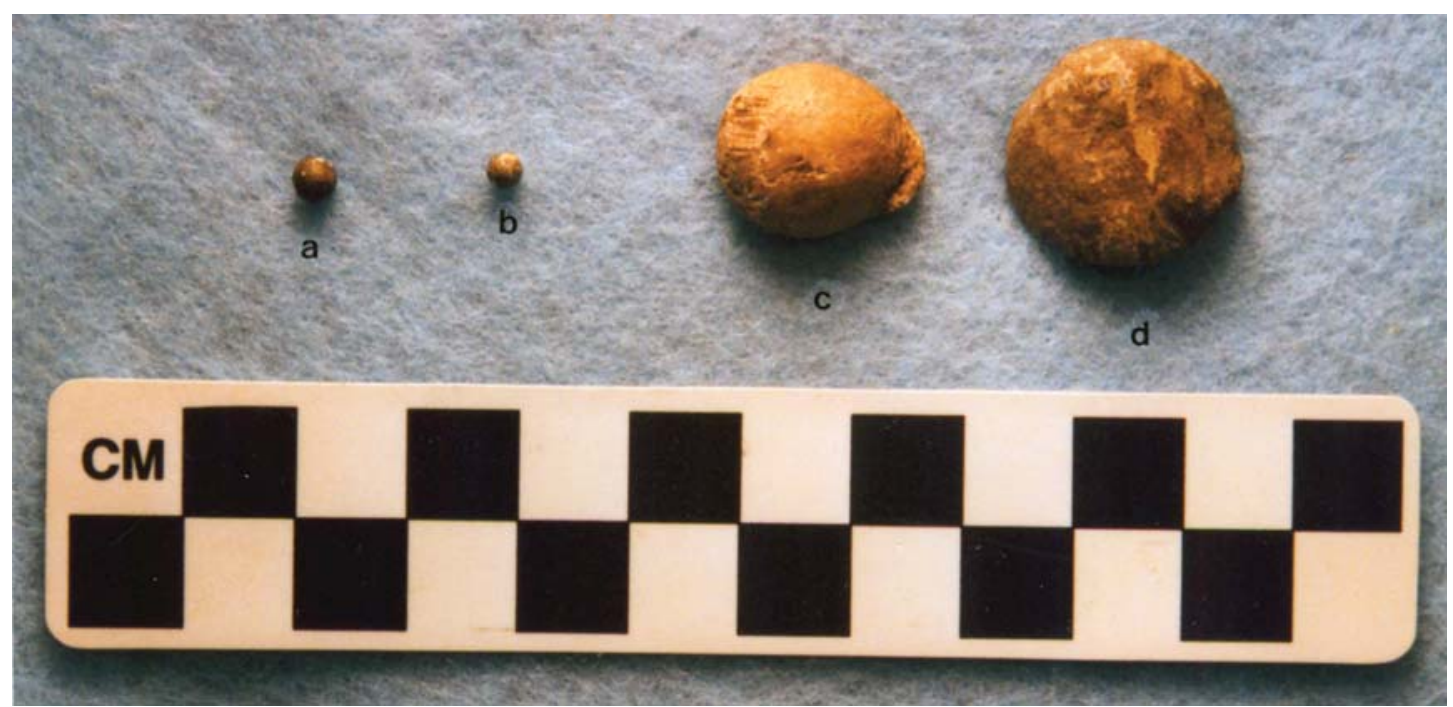

Figure 17. Lead shot and balls.

\section{Gunflint}

The one gunflint (see Figure 16a) was made from a honey-yellow to blond-colored flint, probably from a French source, although some native-made gunflints from the mid- $18^{\text {th }}$ century Gilbert site in Rains County, Texas (Jelks 1967:Figure 41c) resemble this one in overall shape and size. It is a unifacially worked gun spall (with the worked edge opposite the heel, see Kenmotsu [1990:Figure 7]), with a flat dorsal surface, no visible arris lip, and no obvious bulb of percussion on the ventral surface. The gunflint has four straight edges formed by the removal of small thinning flakes around the piece. 


\section{Ceramic Pipe bowl}

The pipe bowl, noted by Krieger from Mr. Moore's collection from the George Moore \#1b site, is from a short-stemmed elbow pipe with a broad bowl, typical of the style of clay pipes found in Allen phase contexts at the Deshazo site (see Napoleon 1995). The pipe bowl is covered with a series of closely-spaced cross-hatched engraved lines (Figure 18); one pipe bowl at the Deshazo site has a crosshatched decoration, except the lines are incised rather than engraved (Napoleon 1995:Figure 53e).

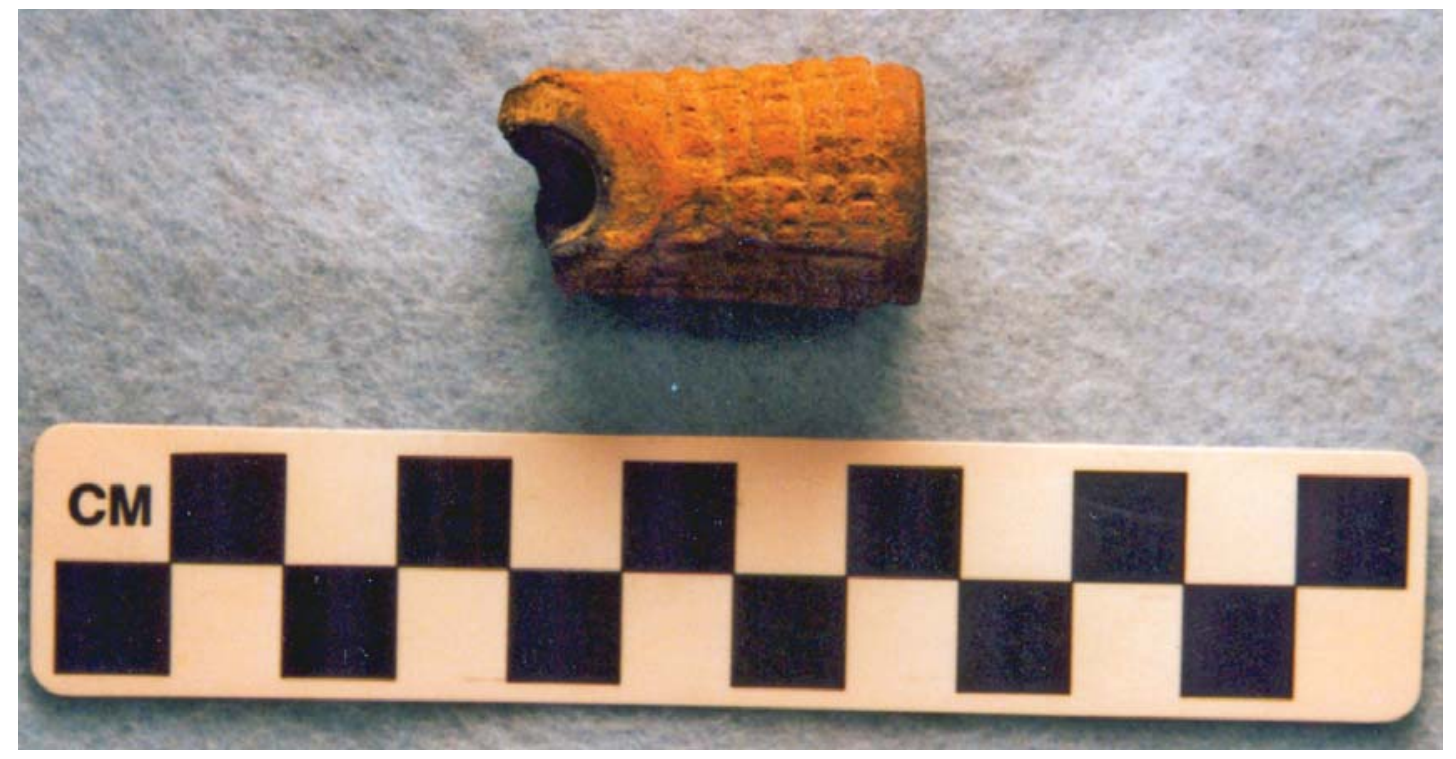

Figure 18. Engraved ceramic pipe bowl.

The bowl is $33.2 \mathrm{~mm}$ in height, with an estimated exterior orifice diameter of $21.0 \mathrm{~mm}$. The bowl walls are 6.1-7.0 mm thick, and they are thickest at the juncture of the bowl with the stem attachment; the pipe was broken at that juncture point.

\section{Dart points}

Three dart points are in the collection from the George Moore \#1b and \#1c sites (Perttula 2004:Figure 13). They do indicate that the area was used by Woodland and Archaic peoples from time to time.

The points are made from a gray chert, possibly available in Neches River stream gravels, but the generally small size of those gravels seem to preclude the possibility that the gray chert was obtained from local sources. The first point (see Perttula 2004:Figure 13a) is a large (83.9 mm in length) contracting stem dart point, very much resembling examples of the Pogo type (see Suhm and Jelks 1962:Plate 82b). The second, of Middle Archaic age (ca. 6000-5800 cal. years B.P.), is a resharpened Calf Creek point (Perttula 2004:Figure 13b) made from a patinated gray chert. The third dart point is an expanding stem-corner-notched Ellis (see Suhm and Jelks 1962:Plate 94h).

In addition to the glass beads and other artifacts from the George Moore \#1b site, Roemer also noted that there was a poorly preserved metal object in the Lively collection that was apparently found in association with one of the burials. It was about $15 \mathrm{~cm}$ long, and may have been a thin iron knife blade; this particular object was not in the collection when I came to document it in 2003. 
During the Krieger 1944 reconnaissance two glass beads were collected from the plowed field along with a chipped stone end scraper. One is a small ( $2.8 \mathrm{~mm}$ in diameter) opaque round white bead (IIa13 in the Kidd and Kidd [1970] classification system) and the other is a large (8.0 $\mathrm{mm}$ in diameter) opaque round blue bead (IIa39). Both bead varieties were the two most common in the $41 \mathrm{HO} 4$ collection documented by Perttula (2004:Table 1), these two varieties comprising more than 92 percent of the bead sample.

In notes on file at the Texas Archeological Research Laboratory, The University of Texas at Austin, Krieger noted that Caddo ceramic sherds from an Allen phase occupation were abundant in the plowed field at the George Moore \#1b site. He identified sherds from Bullard Brushed, La Rue Neck Banded, Maydelle Incised, and Patton Engraved vessels at the site; he also noted fragments on human remains at the site.

\section{HO65, George Moore \#1c}

A catlinite pipe came from the George Moore \#1c site, about $160 \mathrm{~m}$ to the west of the George Moore \#1b site, and also south of the spring branch. Krieger provides no specific information in his 1944 field notes about other artifacts that may have been found or noted there, other than a few fragments of human bone.

The catlinite pipe is a calumet or peace pipe, and would have been used in greeting ceremonies and other rituals by the Caddo, as well as many other tribes living in the eastern United States; the Caddo must have obtained it from the French, as the French widely distributed these pipes to Native American groups in the late $17^{\text {th }}$ and early $18^{\text {th }}$ centuries. Specifically, the pipe from the George Moore \#1c site is the smokestack type of catlinite pipe (see Brain 1979:248).

Henri Joutel witnessed a calumet ceremony in 1687 among the Cahinnio Caddo (Foster 1998:254255), who lived on the Ouachita River in southwestern Arkansas:

In the evening, we attended a ceremony that we had not seen before. A group of elders followed by a few young men and some women came as a group singing at the top of their voices near our hut. The first one carried a calumet [or pipe] decorated with various feathers. Having sung for some time before our hut, they entered the hut and continued their songs for about a quarter of an hour.

The singing and ceremonies with Joutel and other members of his party continued throughout the night.

Then, in the early morning, while the singing continued, "the master of ceremonies took the calumet which he refilled with tobacco, lit, and presented to the Abbe. He drew back and advanced, without giving it to the Abbe, until this was repeated ten times. When he finally put it in the Abbe's hands, he pretended to smoke it and returned it to them. Next, the Indians made us all smoke, and they also all smoked in return, the music always continuing" (Foster 1998:254). The singing and ceremonial activities finally wound down around 9 A.M., according to Joutel, and the Caddo wrapped the calumet in a deer skin sack with "two forked sticks and a crosspiece of red wood," and then they offered the calumet to the Abbe. When they did, they told the French that with the calumet, the French "could go to all the tribes who were their allies with this token of peace and that we would be well received everywhere" (Foster 1998:255).

When Joutel's party came through East Texas in 1687, including the Nabedache Caddo villages along San Pedro Creek, they made no mention of the calumet (Foster 1998:255, fn 8). However, later journeys to these Caddo villages in 1716 and 1718 by Spanish soldiers and missionaries mention the performance of the calumet. Captain Diego Ramon wrote in the diary of his expedition that the calumet pipe was "adorned with many white feathers as a sign of peace among them" (Espinosa 1927:152). 
The pipe has a short, but square stem in cross-section, with a prow protruding from the front of the stem (Figures 19 and 20). The prow also has notched projections along its ridge crest, as well as a $2.5 \mathrm{~mm}$ drilled hole near one end; the drilled hole may have been used to hold feathers. There are two broad incised lines etched into the stem, extending from the stem opening to near the where the cylindrical bowl would have been attached; the bowl is missing, but it was at $10.2 \mathrm{~mm}$ in diameter where it attached to the stem.

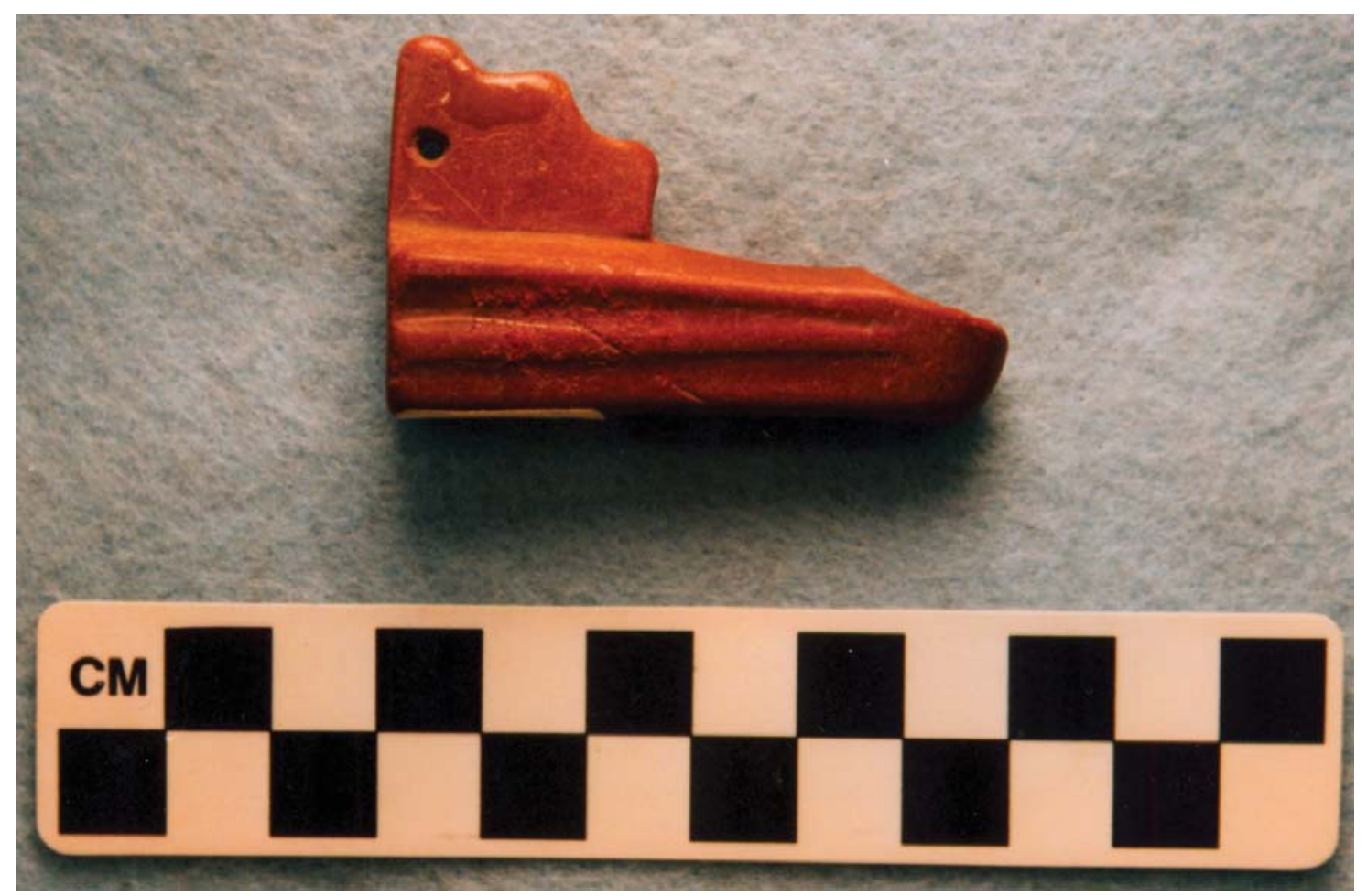

Figure 19. Side-view of the Catlinite pipe.
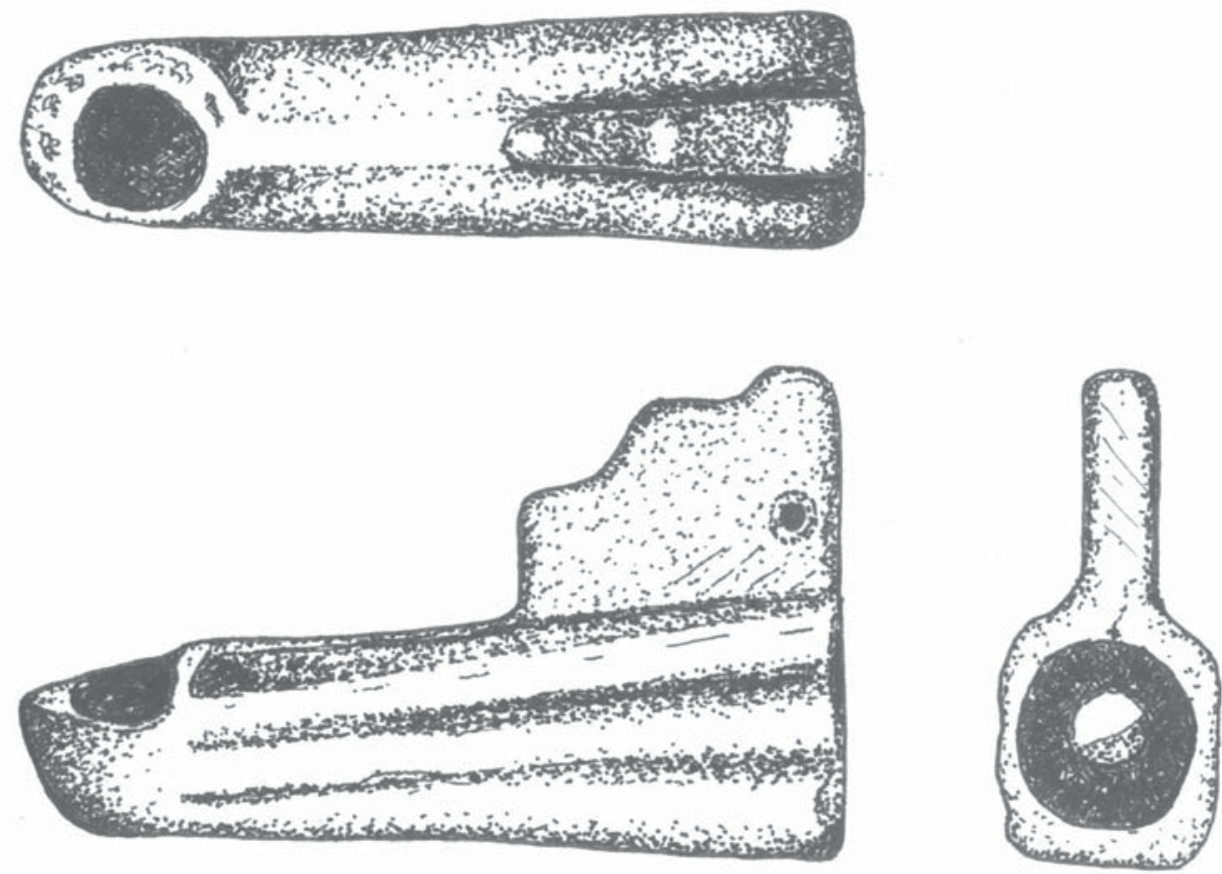

Figure 20. Drawings of the Catlinite pipe: side, top, and stem views. Drawings by Nancy G. Reese. 
According to Thomas E. Emerson and Randall E. Hughes (Perttula 2004:98-99), the red pipestone pipe from the George Moore \#1c site very closely resembles the catlinite material from the Pipestone National Monument area of southwestern Minnesota, although the actual piece could also be from a fragment found in glacial drift sources found some distance to the south. The Portable Infrared Mineral Analyzer (PIMA) spectroscopy of the pipe (cf. Emerson and Hughes 2001:154; Wisseman et al. 2002) completed by Thomas E. Emerson and Randall E. Hughes of the University of Illinois in comparison with a catlinite specimen from the Pipestone National Monument (Perttula 2004:Figure 11) shows a close geochemical correspondence and comparable absorption features.

On Figure 11 in Perttula (2004), Hull spectrum units along the x-axis are in nanometers while the $y$-axis measures the reflectance (i.e., brightness) of the catlinite specimens. The correspondence in spectrum peaks in nanometers and reflectance (i.e., brightness) indicate that the specimen is made from catlinite from the pipestone quarries centered at the Pipestone National Monument.

\section{HO66, George Moore \#2}

This Nabedache Caddo site was situated along the edge of the second or higher alluvial terrace on the west side of San Pedro Creek (see Figure 9). The George Moore \#3 site is not far to the southwest.

Krieger collected six pieces of burned animal bone and 51 Caddo ceramic vessel sherds (Table 4; see also Perttula 2015b). The ceramic sherds are from both grog-tempered (59 percent) and bone-tempered (41 percent) vessels. The plain to decorated sherd ratio (P/DR) is a low 0.24 , which is consistent with this being an Historic Caddo (Nabedache Caddo) ceramic assemblage on San Pedro Creek, not a protohistoric (i.e., pre-A.D. 1680) site as Krieger had suggested in 1944. In other known Historic Caddo sites on San Pedro Creek, P/DR ratios range from 0.32-0.60 (Perttula and Nelson 2006, 2007a, 2007b; Perttula et al. 2011).

Table 4. Ceramic vessel sherds collected by Krieger in 1944 from the George A. Moore Site 2 (41HO66).

\begin{tabular}{|c|c|c|}
\hline Ware/sherd type & Grog-tempered & , \\
\hline
\end{tabular}

Plain Ware

base sherds

body sherds

\section{Utility ware}

\section{Brushed}

diagonal brushing marks horizontal brushing marks

opposed brushing marks

overlapping brushing marks

parallel brushing marks

(1)

3

5

\section{Brushed-Appliqued}

opposed brushed and appliqued node

\section{Neck Banded}


Table 4. Ceramic vessel sherds collected by Krieger in 1944 from the George A. Moore Site 2 (41HO66), cont.

\begin{tabular}{llll}
\hline Ware/sherd type & Grog-tempered & Bone-tempered & $\mathrm{N}$ \\
\hline
\end{tabular}

\section{Utility ware, cont.}

Pinched

parallel pinched ridges

\section{Fine Ware}

Engraved

\begin{tabular}{lccc} 
sets of vertical engraved lines & 1 & - & 1 \\
\hline Totals & 30 & 21 & 51 \\
\hline
\end{tabular}

Sherds with brushed decorations represent 88 percent of the decorated sherds from the site (see Table 4). In other Nabedache Caddo ceramic assemblages on San Pedro Creek, brushed sherds comprise 69.2-76 percent of all the decorated sherds in the Nabedache Caddo ceramic assemblages (Table 5). If the proportion of brushing increases through time, such that sites with the highest percentage of brushed sherds are the youngest in a group of assemblages, and the P/DR value decreases from older to youngest, then the George A. Moore \#2 site could be considered the youngest of the documented Nabedache Caddo ceramic assemblages (41HO91, 41HO211, 41HO214, and 41HO263, see below and Perttula and Nelson 2006, 2007a, 2007b) on San Pedro Creek.

Table 5. Decorative Methods at San Pedro Creek sites.

\begin{tabular}{|c|c|c|c|c|}
\hline \multirow[t]{2}{*}{ Attributes } & \multicolumn{3}{|c|}{ Historic Nabedache Caddo Sites } & \multirow[b]{2}{*}{ 41HO91 } \\
\hline & $41 \mathrm{HO} 263$ & $41 \mathrm{HO} 211$ & $41 \mathrm{HO} 214$ & \\
\hline$\overline{\mathrm{P} / \mathrm{DR}}$ & 0.60 & 0.34 & 0.32 & 0.56 \\
\hline $\begin{array}{l}\% \text { Brushed among } \\
\text { all sherds }\end{array}$ & 36.4 & 53.2 & 56.7 & 44.2 \\
\hline $\begin{array}{l}\% \text { Brushed among } \\
\text { decorated sherds }\end{array}$ & 58.2 & 71.4 & 76.0 & 69.2 \\
\hline $\begin{array}{l}\% \text { Engraved among } \\
\text { all sherds }\end{array}$ & 4.5 & 10.6 & 7.8 & 9.8 \\
\hline $\begin{array}{l}\% \text { Incised among } \\
\text { all sherds }\end{array}$ & 8.0 & 9.6 & 5.3 & 4.9 \\
\hline $\begin{array}{l}\% \text { Punctated among } \\
\text { all sherds }\end{array}$ & 11.4 & - & 2.6 & 3.3 \\
\hline $\begin{array}{l}\% \text { Neck banded } \\
\text { among all sherds } \\
\% \text { Appliqued }\end{array}$ & 1.1 & 2.2 & - & 2.3 \\
\hline among all sherds & - & 1.8 & - & - \\
\hline
\end{tabular}

Sample sizes: 41HO263 (33 plain sherds and 55 decorated sherds); 41HO211 (24 plain sherds and 70 decorated sherds); 41HO214 (55 plain sherds and 172 decorated sherds); 41HO91 (22 plain sherds and 39 decorated sherds), see Perttula and Nelson (2006, 2007a) and Perttula et al. (2011). 
The only substantial difference between these San Pedro Creek Caddo sites is the absence of Patton Engraved fine ware sherds in the small sample from the George A. Moore site, and its ubiquity at the Historic Nabedache Caddo sites. I take the absence of Patton Engraved at the George A. Moore \#2 site to be simply a product of decorated sherd sample size, taking into account the other measurements of very similar decorative methods (see Table 5). For example, 71 percent of all the sherds in the Krieger sample from the George A. Moore \#2 site are brushed, and 88 percent of all the decorated sherds are brushed (see Table 5); these proportions are higher than other Nabedache Caddo sites on San Pedro Creek. The very high proportion of brushed sherds in the George A. Moore \#2 site ceramics was confirmed in 2010 investigations summarized by Perttula et al. (2011:38), although the ceramic sherd assemblage from this work only comprised 15 sherds.

In addition to the many brushed sherds, likely from Bullard Brushed jars, in the assemblage, one body sherd has opposed brushing marks surrounding a single appliqued node (Figure 21a). Two sherds with parallel pinched ridges are from Killough Pinched vessels, and one body sherd with horizontal neck bands is from a La Rue Neck Banded vessel. The only engraved fine ware sherd in the assemblage is from a grog-tempered bottle body sherd. It has at least two sets of three closely-spaced vertical engraved lines that end just above the vessel base (Figure 21b). This sherd may be from either a cylindrical Hume Engraved or Poynor Engraved bottle (see Suhm and Jelks 1962:Plates 42 and 63).

As discussed above, the George A. Moore \#2 site (41HO66) is an Historic Caddo site located not far east of an NPS-plotted route and corridor of El Camino Real de los Tejas (see Perttula and Cast 2010:Table 3). With NPS funding, Perttula et al. (2011) returned to the site to conduct further investigation to locate archaeological deposits associated with the use of El Camino Real de los Tejas.

The George A. Moore \#2 site is on an upland toe slope (230-250 feet amsl) about 40 m north of the current channel of San Pedro Creek. It covers an estimated $8000 \mathrm{~m}^{2}$ (ca. 2 acres), based on the surface distribution of artifacts and the excavation of ST 1-9 on the Lovell tract (Figure 22). Archaeological deposits range from $20-60 \mathrm{~cm}$ in thickness across the site, and they contain chipped and ground stone
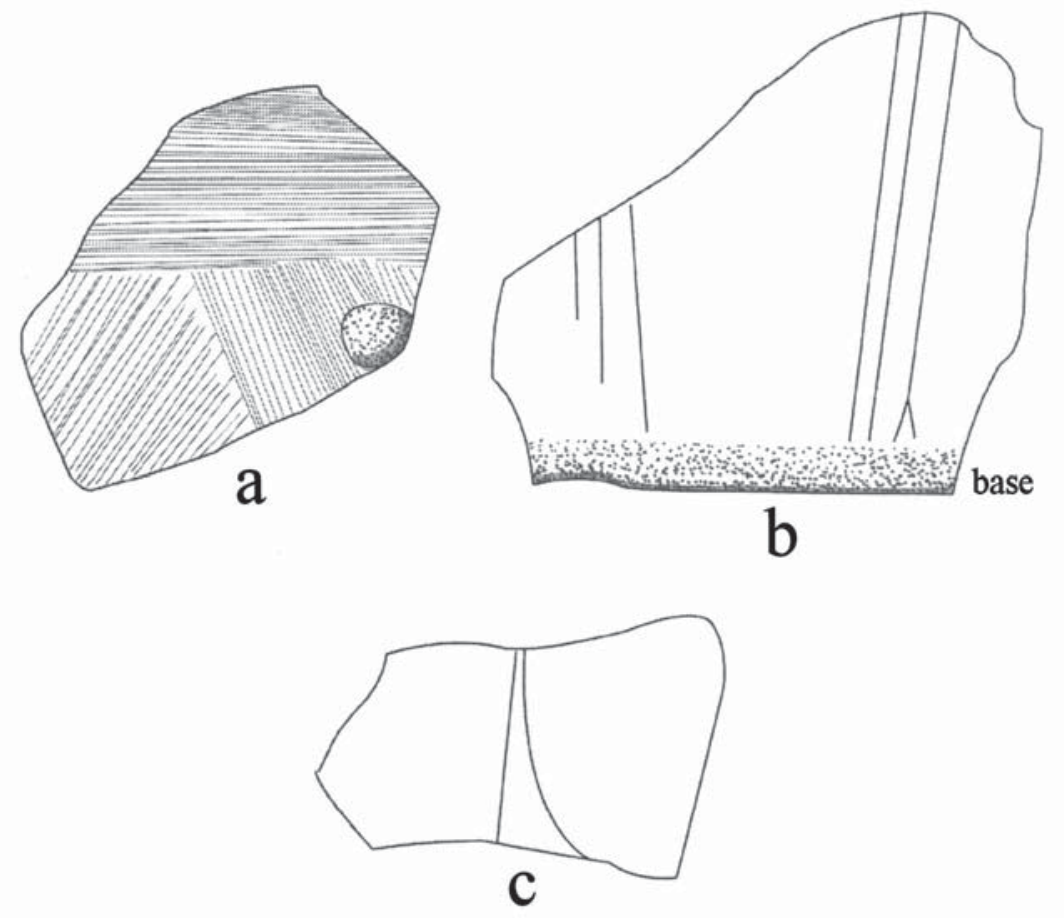

Figure 21. Decorative elements on selected ceramic sherds: a, brushed-appliqued body sherd from 41HO66; b, engraved bottle body sherd from 41HO66; c, cf. Poynor Engraved body sherd from 41HO69. 
artifacts, plain and decorated body sherds (Table 6), and a few pieces of animal bone (see Schniebs, below). The density of artifacts in the shovel testing is 4.71 per positive shovel test, or ca. 37.7 artifacts per $\mathrm{m}^{2}$. The highest densities of sherds are in ST 1,2, and 5, near the tip of the landform, while lithic artifacts are more abundant in ST 1, 3, 5, and 6, in the same general area (Figure 22).

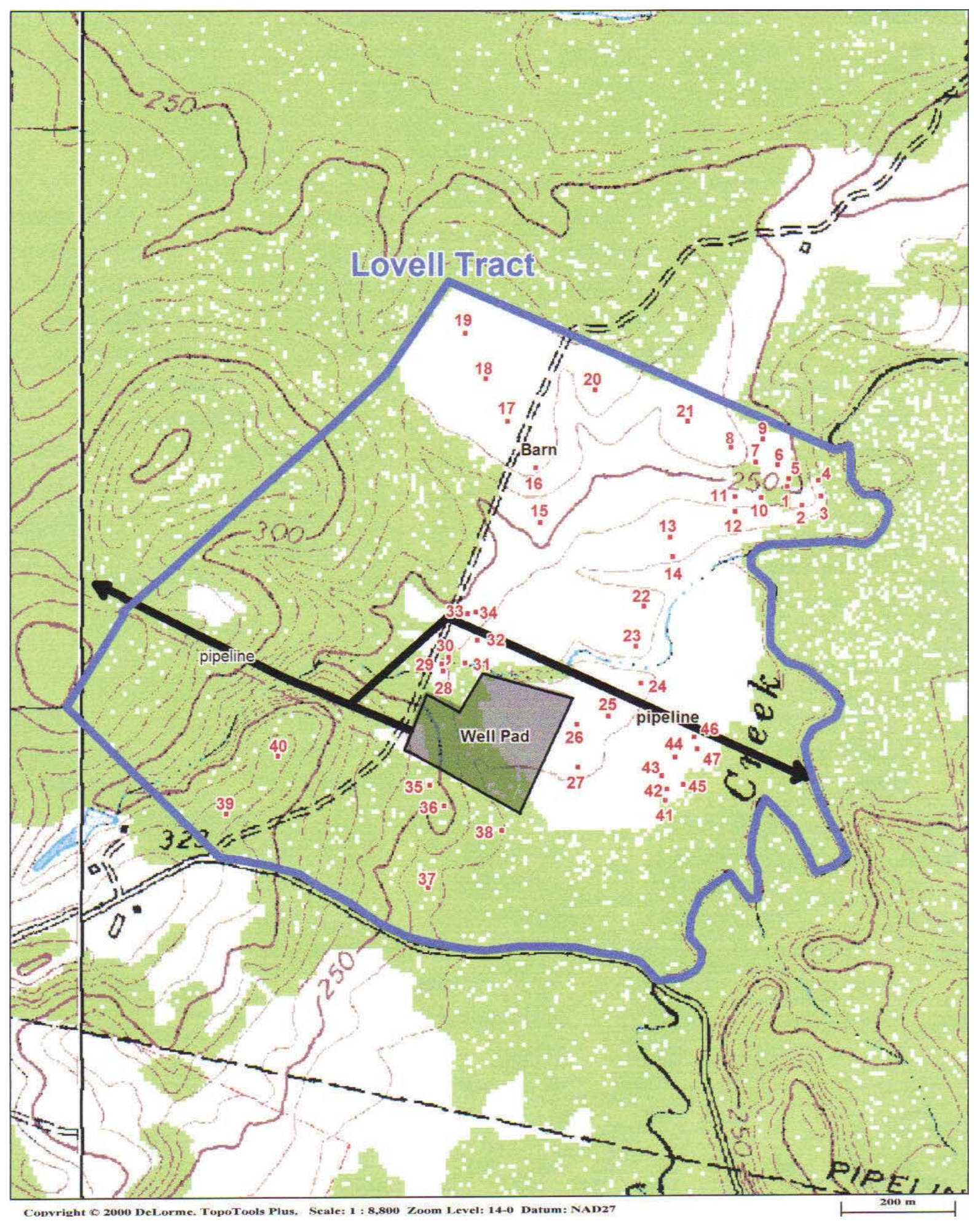

Figure 22. Location of ST 1-47 on the Lovell Tract. 
Table 6. Artifacts recovered from the George A. Moore \#2 site on the Lovell tract.

\begin{tabular}{llllll}
\hline $\begin{array}{l}\text { Provenience } \\
(\mathrm{cm} \mathrm{bs})\end{array}$ & $\begin{array}{l}\text { Lithic } \\
\text { Debris }\end{array}$ & $\begin{array}{l}\text { Ground } \\
\text { Stone Tool }\end{array}$ & $\begin{array}{l}\text { Plain } \\
\text { Sherd }\end{array}$ & $\begin{array}{l}\text { Decorated } \\
\text { Sherd }\end{array}$ & N \\
\hline Surface & 1 & - & - & 5 & 6 \\
ST 1, 0-60 & 4 & - & - & 3 & 7 \\
ST 2, 0-20 & - & - & - & 4 & 4 \\
ST 3, 0-60 & 9 & - & 1 & - & 9 \\
ST 4, 0-20 & - & - & - & - & 1 \\
ST 5, 0-60 & 3 & - & - & - & 5 \\
ST 6, 0-60 & 5 & - & - & - & 1 \\
ST 7, 0-20 & 1 & 1 & 1 & 14 & 39 \\
\hline Totals & 23 & &
\end{tabular}

The ceramic sherds from the George A. Moore \#2 site are primarily from brushed utility ware jars, although the assemblage of sherds is rather small $(n=15)$. Approximately 86 percent of the decorated sherds are brushed (parallel brushed, $n=9$; opposed brushed, $n=3$ ), and 80 percent of all the sherds from the site are brushed. The plain/decorated sherd ratio (P/DR) is a very low 0.07 . These percentages and $\mathrm{P} / \mathrm{DR}$ values are consistent with this being an Historic Caddo (Nabedache Caddo) ceramic assemblage on San Pedro Creek (Perttula and Nelson 2006, 2007a). In other known Historic Caddo sites on San Pedro Creek, P/DR ratios range from 0.32-0.60, and the percentage of brushed sherds among all sherds is 36.4-56.7 percent. Finally, brushed sherds comprise 69.2-76 percent of all the decorated sherds in the Nabedache Caddo ceramic assemblages. If the proportion of brushing increases through time, such that sites with the highest percentage of brushed sherds are the youngest in a group of assemblages, and the $\mathrm{P} / \mathrm{DR}$ value decreases from older to youngest, then the George A. Moore \#2 site is the youngest of the documented Nabedache Caddo ceramic assemblages (41HO91, 41HO211, 41HO214, and 41HO263, see above and Perttula and Nelson 2006, 2007).

The other decorated sherds in the George A. Moore \#2 sherd assemblage include a body sherd (ST 1, 0-20 cm bs) with opposed engraved lines (untyped), and a parallel grooved body sherd (ST 2, 0-20 cm) from a Lindsey Grooved jar. This kind of utility ware is a recently recognized Historic Caddo utility ware in the Neches-Angelina river basin (Perttula et al. 2010).

Grog, bone, and hematite were used to temper the vessels at the site, either as the sole temper, or in combination with other tempers. Grog was present in 50 percent of the analyzed sherds, compared to 50 percent for sherds with bone, and 60 percent with hematite temper inclusions. These are much higher proportions of bone temper use than has been documented at other Historic Caddo sites along San Pedro Creek (see Perttula and Nelson 2006, 2007a, see below). A naturally sandy clay was occasionally used to manufacture vessels, represented by 20 percent of the sherds from the site analyzed in detail (see Perttula et al. 2011:Appendix 3).

The sherds are from vessels that were fired and cooled in a high oxygen environment (10 percent); incompletely oxidized during firing (40 percent); fired and cooled in a reducing environment (10 percent); fired in a reducing environment and cooled in the open air (30 percent), and one sherd (10 percent) from a vessel that was fired in an irregular way, with a lighter core than their surfaces. Aten and Bollich (2002:54-55) suggest that vessels with this kind of firing may have been placed in a fire with the "orifice [of the vessel] facing into the fire." Furthermore, the sherds with cores lighter than the surfaces may have come from vessels where "after extended firing that burned off all organics, the fire may have been smothered to cause reduction and darkening of the exterior surface." It is interesting that the vessel firing practices apparent in the sherds found at the George A. Moore \#2 site are quite different from other His- 
toric Caddo Nabedache sites, in that the latter are dominated (68-79 percent) by sherds fired in a reducing environment and cooled in the open air (see Perttula and Nelson [2006, 2007a], and the discussion that follows concerning the ceramic sherds from the Ivie \#1 site on San Pedro Creek).

The lithic artifacts from the site are apparently a product of the manufacture of chipped stone tools during the Caddo occupation of the site, as there is no evidence of an earlier pre-ceramic Archaic or Woodland period ceramic-bearing occupation. In addition to the lithic debris, there is a single ferruginous sandstone grinding slab fragment from ST $5(20-40 \mathrm{~cm} \mathrm{bs})$ (see Table 6). The fragment is at least $76 \mathrm{~mm}$ in length and $46 \mathrm{~mm}$ in width.

Raw materials represented in the lithic debris assemblage at the George A. Moore \#2 site include the following local materials: petrified wood ( $n=8 / 50$ percent cortical), quartzite $(n=6 / 67$ percent cortical, including a core fragment), and Glover quartzite $(n=2 / 50$ percent cortical, see Perttula and Nelson [2006] for a discussion concerning this distinctive Neches River basin raw material). These raw materials comprise 69.6 percent of the lithic debris from the site. Probable non-local lithic raw materials (most likely from Central Texas source areas or expansive gravel deposits east of the Edwards Plateau) in the lithic debris are: black-white banded chert $(n=1 / 0$ percent cortical), translucent gray chert $(n=1 / 0$ percent cortical), and gray chert ( $\mathrm{n}=5 / 0$ percent cortical). These much rarer tool stones account for 30.4 percent of the lithic debris sample.

\section{Faunal Remains, by LeeAnna Schniebs}

Six faunal specimens were recovered from two levels in two shovel tests (ST 2, 20-40 cm bs and ST 5, 20-60 cm bs) at the George A. Moore \#2 site, and three fragments were collected from the surface of the site. The collection consists of seven large mammal bone fragments, one deer tooth fragment from ST 2 , and a small piece of burned turtle shell from ST $5(20-40 \mathrm{~cm} \mathrm{bs})$. The sample weighs 1.7 grams.

\section{HO67, George Moore \#3}

The George A. Moore \#3 site (41HO67) is on the same alluvial terrace as the George Moore \#2 site (see Figure 9). Krieger collected a total of six Caddo sherds from the site: one grog-tempered base sherd, a grog-tempered Killough Pinched body sherd, and four grog-tempered brushed rim and body sherds. The one rim, from a Bullard Brushed jar, has horizontal brushing marks, while the body sherds have vertical brushing marks. In the absence of Patton Engraved sherds or European trade goods, this site is most likely an ancestral Nabedache Caddo site that was occupied prior to ca. A.D. 1650, although the TARL inventory sheet of artifacts from it mentions that two glass beads were in a surface collection from the site (Perttula 2004:87).

\section{HO68, George Moore \#4}

In Krieger's 1944 reconnaissance of the lower San Pedro Creek valley, he noted the George Moore \#4 site on a map as located in a plowed field on the east side of San Pedro Creek (see Figure 9). Other than its location along the edge of the floodplain, Krieger made no other comments about the site. Thus, its cultural and temporal affiliation is unknown, although it is suspected to be an ancestral Caddo site.

\section{HO69, George Moore \#5}

Only a small sample of Caddo ceramic sherds were collected from the George Moore \#5 site, downstream a short distance from the other sites (see Figure 9), during the 1944 reconnaissance. This includes a grog-tempered parallel brushed body sherd, a plain bone-tempered body sherd, and a bonetempered Poynor Engraved carinated bowl body sherd (see Figure 21c). This sherd may be from a Poynor Engraved, var. Cook vessel (see Perttula 2011:Figure 6-64c-d). This variety of Poynor Engraved was 
apparently made from ca. A.D. 1400-1650, but was most common on Caddo sites in the Neches River basin dating between ca. A.D. 1400-1560 (Perttula 2011:Table 6-37). This suggests that the George Moore \#5 site is an ancestral Nabedache Caddo site, occupied well before sustained European contact.

\section{$41 \mathrm{HO91}$ and $41 \mathrm{HO91B}$}

41HO91 was estimated by Erickson and Corbin (1996) to cover approximately 1.2 acres of a low sandy rise at the edge of the San Pedro Creek floodplain. During their work at the site they recovered a Perdiz arrow point (Erickson and Corbin 1996:Figure 9b), five pieces of lithic debris, a chert scraper, a sherd of Patton Engraved (a temporal and cultural diagnostic of Historic Hasinai Caddo settlements in the Neches and Angelina River basins), three incised sherds, three brushed sherds, a brushed-incised sherd, and a punctated sherd, a pipe bowl sherd, and a glass trade bead (Erickson and Corbin 1996:Figure 9d). The ceramic sherds were tempered with grog, grog-bone, and sand.

During the 2007 archaeological investigations at the site (Perttula and Nelson 2007a), 18 positive shovel tests were excavated in the wooded part of $41 \mathrm{HO} 91$ (ca. 239 feet amsl) at the base of the uplands (Figure 23), and several of these shovel tests did contain metal artifacts. The majority of them, however, did have Caddo ceramic and lithic artifacts. The 18 positive shovel tests defined an area of habitation deposits that covers a ca. 58 x $45 \mathrm{~m}$ (2610 square meters or 0.65 acre) area (Figure 23). Although the UTM coordinates provided on the 1990s site form submitted by James E. Corbin led us to this wooded locale, the description of the site in Erickson and Corbin (1996) indicates that they were referring to 41HO91B in the pasture/old field (Figure 23) rather than to the wooded component of $41 \mathrm{HO} 91$ we newly documented in these investigations.

Thirty-one artifacts were recovered from this part of 41HO91 during the metal detecting and shovel test investigations (Table 7). More than 70 percent of the recovered artifacts from $41 \mathrm{HO} 91$ are Caddo ceramic vessel sherds. The plain-decorated sherd ratio (P/DR) is a low 0.47, and consistent with an Historic Caddo Allen phase ceramic assemblage in the Neches-Angelina River basins. The P/DR at $41 \mathrm{HO} 91 \mathrm{~B}$ is 0.46 and 0.39 at 41HO122, although the sample sizes are small. At the Nabedache Blanco site (41HO211), the P/DR is 0.31, compared to 0.32 at the Nabedache Azul site (41HO214) (Perttula and Nelson 2006:62).

Table 7. Recovered Artifacts from 41HO91, 41HO91B, 41HO122, and $41 \mathrm{HO} 47$.

\begin{tabular}{llclll}
\hline $\begin{array}{l}\text { Artifact } \\
\text { Class }\end{array}$ & $41 \mathrm{HO} 91$ & $41 \mathrm{HO} 91 \mathrm{~B}$ & $41 \mathrm{HO} 122$ & $41 \mathrm{HO} 147$ & $\mathrm{~N}$ \\
\hline Plain sherd & 7 & 11 & 9 & 1 & 28 \\
Decorated sherd & 15 & 24 & 23 & 1 & 63 \\
Burned clay & - & 1 & - & - & 1 \\
Daub & - & 1 & - & - & 1 \\
Lithic debris & 3 & 25 & 6 & - & 37 \\
Scraper & 1 & - & - & - & 1 \\
Flake tool & - & - & 1 & - & 1 \\
Ground stone & - & - & 1 & - & 4 \\
Cut nail & 3 & - & 3 & - & 5 \\
Iron artifacts & 2 & 2 & 1 & - & 3 \\
Animal bone & - & 65 & 44 & 5 & 145 \\
\hline Total & 31 & & & & \\
\hline
\end{tabular}




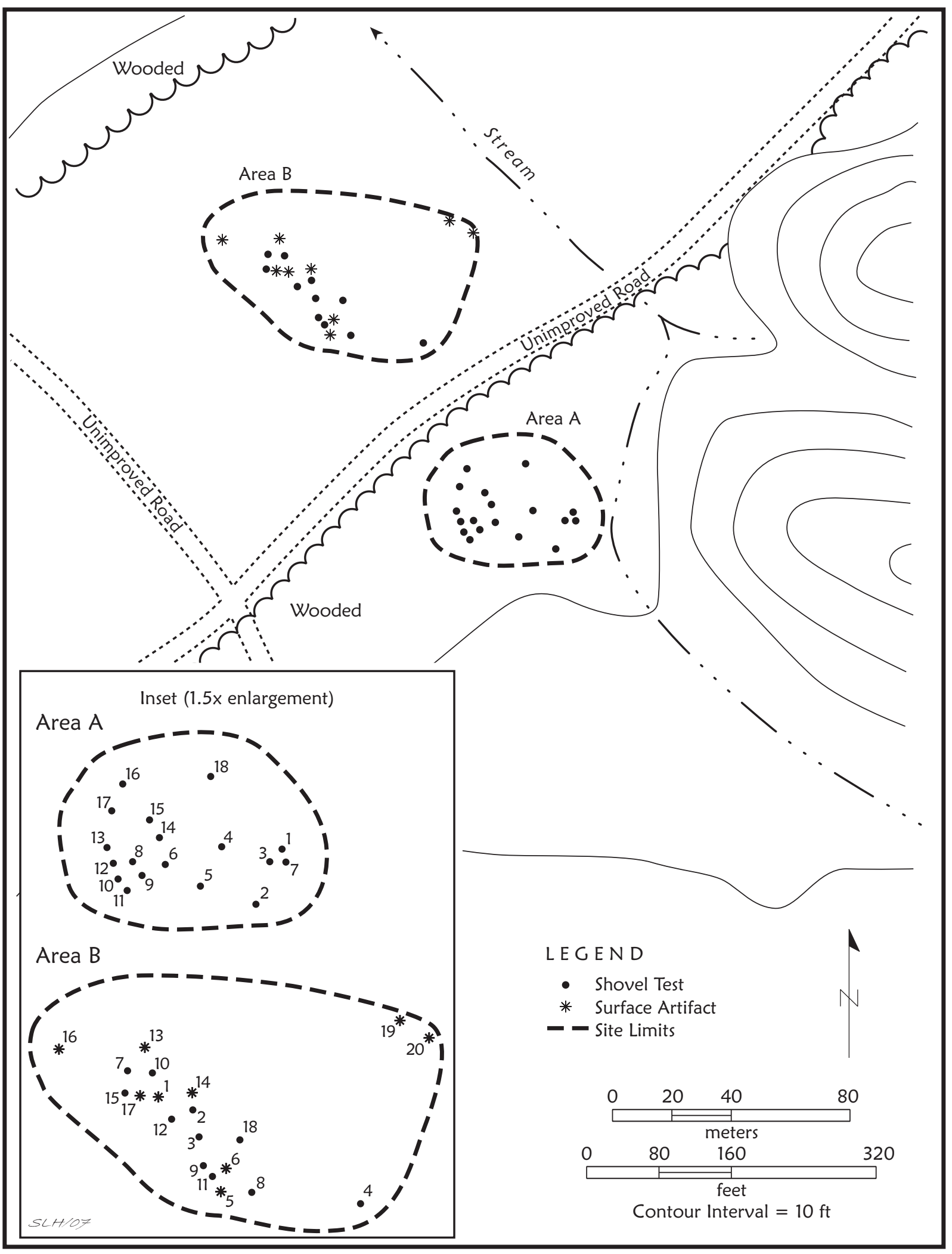

Figure 23. Map of shovel tests and surface artifacts at 41HO91 and 41HO91B. 
The 22 sherds include 15 from decorated fine wares $(n=4)$ and utility wares $(n=11)$ (Table 8). Almost 70 percent of the decorated sherds have brushing on them, either by itself (and presumably covering the body of utility ware jars) or in association with appliqued ridges that probably divided the brushing on vessel bodies into vertical panels. The high frequency of brushing at 41HO91, as well as at 41HO91B and $41 \mathrm{HO} 122$, in conjunction with the low P/DR, is also consistent with an Allen phase ceramic assemblage at these three different site areas. By way of comparison, over 70 percent of the decorated sherds at the nearby Nabedache Blanco site are brushed, as are more than 76 percent of the decorated sherds at the Nabedache Azul site (Perttula and Nelson 2006:Tables 5 and 8). Almost 80 percent of the decorated sherds are brushed in the Plev Cutler decorated sherd collection ( $\mathrm{n}=619$ decorated sherds) from the general Mission Tejas State Park area along San Pedro Creek (Perttula et al. 2007), and Patton Engraved and Hume Engraved, Allen phase ceramic diagnostics, are the most common engraved fine wares in these collections.

Table 8. Decorative Elements on Sherds from 41HO91, 41HO91B, and $41 \mathrm{HO122.}$

\begin{tabular}{|c|c|c|c|}
\hline Decorative Element & 41HO91 & 41HO91B & $41 \mathrm{HO} 122$ \\
\hline \multicolumn{4}{|l|}{ Engraved } \\
\hline \multicolumn{4}{|l|}{ horizontal-diagonal } \\
\hline and hatched triangle & - & - & 1 \\
\hline $\begin{array}{l}\text { horizontal and diagonal } \\
\text { panel }\end{array}$ & 1 & - & 1 \\
\hline hatched triangle & - & 1 & 1 \\
\hline small hatched pendant triangle & 1 & - & - \\
\hline ticked lines & - & 1 & \\
\hline straight line & 2 & - & 1 \\
\hline $\begin{array}{l}\text { parallel-curvilinear lines, } \\
\text { closely-spaced }\end{array}$ & - & - & 1 \\
\hline \multicolumn{4}{|l|}{ Utility Wares } \\
\hline parallel brushed & 7 & 16 & 14 \\
\hline overlapped brushed & - & 1 & 2 \\
\hline opposed brushed & 2 & - & 1 \\
\hline $\begin{array}{l}\text { parallel brushed-appliqued } \\
\text { ridge }\end{array}$ & 1 & - & - \\
\hline horizontal incised lines & - & - & 1 \\
\hline $\begin{array}{l}\text { parallel incised, closely- } \\
\text { spaced }\end{array}$ & 1 & - & - \\
\hline single straight incised line & - & 2 & - \\
\hline single tool punctated & - & 1 & - \\
\hline tool punctated rows & - & 1 & - \\
\hline pinched rows & - & 1 & - \\
\hline$\%$ brushed & 60 & 71 & 74 \\
\hline$\%$ brushed-appliqued & 7 & - & - \\
\hline $\mathrm{N}$ & 15 & 24 & 23 \\
\hline
\end{tabular}


In addition to the brushed utility ware sherds, there are two sherds decorated with simple incised line decorative elements (see Table 8). These may be from effigy vessels decorated with horizontal incised lines around the rim of bowls.

The four engraved sherds include two nondescript sherds with a single straight line on them, along with two others. The first has a horizontal and diagonal element on a carinated bowl, while the other is from a Hume Engraved vessel with a single hatched engraved triangle pendant from a horizontal line encircling the rim.

All the vessel sherds from 41HO91 are tempered with grog (or crushed sherds), but almost 39 percent have crushed hematite inclusions (Table 9). The proportion of hematite temper here is roughly comparable to the ceramic vessel sherds from $41 \mathrm{HO} 91 \mathrm{~B}$, but occurs in much higher frequencies here than it does at either 41HO122 or the Nabedache Blanco and Nabedache Azul site ceramic assemblages (Perttula and Nelson 2006:Table 3 and Figure 37). The absence of bone-tempered ceramics at 41HO91 is notable, particularly given its popularity (all more than 20 percent) in the assemblages from 41HO91B, 41HO122, Nabedache Blanco, and Nabedache Azul.

Table 9. Temper, Paste, and Firing Conditions in a Sample of Sherds from 41HO91, 41HO91B, and $41 \mathrm{HO122.}$

\begin{tabular}{llll}
\hline Temper & $41 \mathrm{HO} 91$ & $41 \mathrm{HO} 91 \mathrm{~B}$ & $41 \mathrm{HO} 22$ \\
\hline grog & $61.1^{*}$ & 38.1 & 66.7 \\
grog-hematite & 38.9 & 33.3 & 5.6 \\
grog-bone & - & 9.5 & 11.1 \\
bone-hematite & - & 9.5 & - \\
hematite & - & 4.8 & - \\
bone-grog-hematite & - & 4.8 & 16.7 \\
bone & - & - & 27.8 \\
\% with bone & 0.0 & 23.8 & 5.6 \\
\% with hematite & 38.9 & 52.4 & 18 \\
$\mathrm{~N}$ & 18 & 21 & $41 \mathrm{HO} 22$ \\
\hline Paste & $41 \mathrm{HO} 91$ & $41 \mathrm{HO} 91 \mathrm{~B}$ & 54.5 \\
\hline Clay & $33.3^{*}$ & & 45.5 \\
Sandy & 66.7 & 28.6 & 22 \\
$\mathrm{~N}$ & 18 & 71.4 & $41 \mathrm{HO} 22$ \\
\hline Firing Conditions & $41 \mathrm{HO} 91$ & 21 & 19.0 \\
\hline Oxidizing & $27.8^{*}$ & $41 \mathrm{HO} 91 \mathrm{~B}$ & 14.3 \\
Reducing & 11.1 & 14.3 & 9.6 \\
Incompletely Oxidized & 11.2 & 19.0 & 57.1 \\
Reducing, but cooled & 50.0 & 14.3 & \\
in open air & & 52.5 & 21 \\
$\mathrm{~N}$ & 18 & & \\
\hline
\end{tabular}

*percentage 
Sandy paste vessel sherds are especially abundant at 41HO91, and 41HO91B (see Table 9). Sandy paste clays were obviously selected for vessel manufacture by the Nabedache Caddo potters living at this site, more so than is the case at either 41HO122, Nabedache Blanco, or Nabedache Azul (Perttula and Nelson 2006:Table 3).

The vessel sherds from 41HO91 were primarily from vessels fired in a low oxygen or reducing environment (see Table 9). Most of these vessels were subsequently cooled in the open air, which led to the formation of thin oxidized zones along one or both sides of the vessel surface (see Teltser 1993:Figure $2 \mathrm{f}-\mathrm{h}$ ). The same vessel firing practices were in place by the Caddo residents living at 41HO91B and 41HO122, as well as at the Nabedache Blanco and Nabedache Azul sites (Perttula and Nelson 2006:Table 4). The Nabedache Caddo potters were apparently able to successfully regulate the firing and cooling of the ceramic wares used by the residents of the Nabedache Caddo village along San Pedro Creek.

The four lithic artifacts from 41HO91 includes three pieces of lithic debris and a flake scraper or possible gunflint fragment. This tool (ST 91-12, 10-20 cm bs) is made from a gray chert and has a steep and scalloped working edge. All three of the pieces of lithic debris are on chert: yellowish-brown chert $(n=1)$, grayish-brown chert $(n=1)$, and a honey-colored chert $(n=1)$. The one cortical piece (the yellowish-brown chert) has a smoothed cortex, suggesting it had come from a pebble or cobble obtained from stream gravels, probably from the Neches River.

The honey-colored chert or flint piece (ST 91-15, 0-20 cm bs) resembles the material from one of the gunflints recovered at the Nabedache Azul site (Perttula and Nelson 2006:Figure 54a), and it is likely that this piece of debris is a remnant of a blade gunflint. The piece has a visible dorsal ridge scar and one edge has been trimmed or has use-wear damage.

Three $19^{\text {th }}$ century cut nails were recovered from three separate metal detector hits/shovel tests in the eastern part of $41 \mathrm{HO} 91$. There may have been a structure erected here dating from the mid- $19^{\text {th }}$ century, sometime after the Nabedache Caddo abandoned the San Pedro Creek valley. Other metal artifacts from this area include an iron hinge with three suspension holes; two cut nails were still in place in these holes, and their purpose would have been to hold the hinge in place, probably along a door or cabinet. The other metal artifact $(\mathrm{ST} 1,0-20 \mathrm{~cm}$ ) is an iron trigger from a French flintlock musket (see Jelks 1967:Figure 35o, q).

\section{$41 \mathrm{HO91B}$ (Field)}

Site 41HO91B is about 60 m north of the wooded section of 41HO91, in a thickly overgrown pasture or old field with scattered small pines, brush, and thick grasses. A total of 12 shovel tests were excavated during the course of investigating possible metal detector hits at the site (which we are keeping separate from $41 \mathrm{HO} 91$ in the woods) that contained artifacts, and nine separate surface finds of artifacts were also documented here (see Figure 23). This component of 41HO91 is estimated to cover a ca. $92 \times 55 \mathrm{~m}$ area or approximately 5060 square meters (1.25 acres).

Sixty-five artifacts were collected from shovel tests and surface contexts at 41HO91B (see Table 7). Ceramic vessel sherds comprise 54 percent of the artifact assemblage, and lithic debris accounts for another 38 percent of the total. The frequency of lithic debris at 41HO91B compared to 41HO91 (9.7 percent) and 41HO122 (13.6 percent), as well as at Nabedache Azul (8.3 percent), suggests a heightened emphasis here in chipped stone tool manufacture. Such was also the case, but even more so, at the Nabedache Blanco site, where lithic debris accounted for more than 75 percent of the 736 artifacts recovered there during recent test excavations (Perttula and Nelson 2006:Table 1). 
The 35 sherds from 41HO91B include 11 plain sherds and 24 decorated sherds. Most of the decorated sherds are from utility ware vessels (92 percent). The P/DR is 0.46 .

The two engraved sherds include a Poynor Engraved body sherd with a hatched triangular element and a Patton Engraved body sherd with ticking (see Table 8). The Patton Engraved bowl sherd (Surface find, 91B1-1) has two widely-spaced curvilinear engraved lines on the vessel rim with small triangular tick marks on them, and these intersect a third but straight engraved line with the same kind of tick marks on it.

The most common decorated utility wares at the site are brushed sherds (71 percent), mostly with parallel or vertical brushing marks. Other decorated utility wares include two with a single straight incised line, two with tool punctates, and a Killough Pinched body sherd with at least two rows of pinching.

The ceramics from 41HO91B have a diverse range of tempers added to the paste of vessels (see Table 9). This includes grog, bone, and hematite inclusions in various combinations, with 23.8 percent having bone temper and another 52.4 percent with crushed hematite inclusions. Most of the sherds from the site are from vessels made with a naturally sandy clay-comparable in proportions to the vessel sherds from 41HO91 (see Table 9).

Like 41HO91 and 41HO122, most of the vessel sherds from 41HO91B are from vessels fired in a reducing environment, then cooled in a high oxygen environment (52.5 percent, see Table 9). Another 19 percent of the sherds are from vessels fired in a reducing environment.

One honey-colored chert flake tool was recovered in ST 91B-11 $(0-20 \mathrm{~cm} \mathrm{bs})$. It had evidence of use along one lateral edge, and given the distinctive raw material, may be a remnant of a broken gunflint.

The 25 pieces of lithic debris are from a wide variety of raw materials, including cherts of different colors, petrified wood, novaculite, quartzite, and a distinctive gray "sugary-textured" quartzite that may originate locally in the Glover Sandstone Formation (Girard 1995:69; Perttula and Nelson 2006:85). Cherts comprise 64 percent of the lithic debris (Table 10), and almost all of this material is non-cortical.

Table 10. Lithic Debris from 41HO91B.

\begin{tabular}{llll}
\hline $\begin{array}{l}\text { Raw Material } \\
\text { (smooth) }\end{array}$ & Non-cortical & Cortical (rough) & Cortical \\
\hline petrified wood & 3 & - & 1 \\
$\begin{array}{l}\text { quartzite } \\
\text { "sugary" quartzite }\end{array}$ & 1 & 2 & - \\
$\begin{array}{l}\text { dark grayish-black } \\
\quad \text { chert }\end{array}$ & 1 & 1 & 1 \\
dark brown chert & 2 & - & 1 \\
black chert & - & - & - \\
light gray chert & 1 & - & - \\
brown chert & 1 & - & - \\
dark gray chert & 1 & - & 2 \\
gray chert & 1 & - & - \\
novaculite & 5 & - & 6 \\
\hline Totals & 1 & 3 & \\
\hline
\end{tabular}

Petrified wood accounts for 16 percent of the lithic debris, quartzite another 4 percent, and the "sugary" Glover Sandstone quartzite another 12 percent. The remaining piece of lithic debris is a piece of 
non-local novaculite (4 percent) from the Ouachita Mountains and/or Red River gravels a considerable distance from San Pedro Creek; this piece must have come off a completed tool made from novaculite that was resharpened or finished at 41HO91B. At the Nabedache Blanco site, Glover Sandstone quartzite, petrified wood, and quartzite were the three most common raw materials represented in the lithic debris, accounting for more than 76 percent of the 518 pieces found in the test excavations at this Allen phase component (Perttula and Nelson 2006:Table 11). The Nabedache Caddo occupants of 41HO91B used more chert raw materials than did the residents of the Nabedache Blanco site, and probably had better access to such fine-grained siliceous materials. By comparison, 96 percent of the lithic debris from the Nabedache Azul site was chert (Perttula and Nelson 2006:87).

At least two different sources of local lithic raw material were exploited by the Caddo knappers living at 41HO91B. The first and principal source were stream gravels-probably in the Neches River floodplain - where cortically smooth stream-rolled raw material would have been gathered (see Table 10). A secondary source must be from non-stream gravels based on the cortex being roughened and nonsmoothed (Perttula and Nelson 2006:87). Raw materials with this kind of cortex include only the Glover Sandstone quartzite and a dark grayish-black chert

Other incidental artifacts found in the 41HO91B shovel testing include burned clay ( $\mathrm{n}=1$, ST B-1, 0-20 cm bs), daub ( $\mathrm{n}=1$, ST 91B-8, 0-20 cm bs), and burned animal bone ( $\mathrm{n}=2$, ST 91B-11, 0-20 cm bs), evidence of structure and outdoor cooking activities and trash disposal. No European metal goods were recovered in the shovel testing investigations at the site.

In late March 2007, we returned to 41HO91, 41HO91B, 41HO122, and 41HO147 at Mission Tejas State Park to conduct additional metal detecting, shovel testing, and surface collections. Conditions had improved since our earlier archeological investigations in February 2007 (Perttula and Nelson 2007a), and we wished to follow up these earlier investigations with targeted metal detecting and shovel testing in areas where Colonial-era metal artifacts had been found in that work. At $41 \mathrm{HO} 147$, the previous water-logged conditions limited the number of shovel tests we were able to excavate in February 2007, so returning to the site area in late March when it was drier allowed us to explore the likely site area and determine if the archaeological materials discovered by Erickson and Corbin (1996) at the site were indeed shallowly buried in the San Pedro Creek floodplain.

Four additional shovel tests (ST 19-20, 22-23) in the eastern part of 41HO91 contained archaeological materials (Table 11). These materials include five wire nails, three cut nails, four nail shank fragments, two chert pieces of lithic debris, and a single plain grog-tempered body sherd in ST 20.

Table 11. Recovered archaeological materials from $41 \mathrm{HO91}$ during March 2007 investigations.

\begin{tabular}{ll}
\hline Provenience & Material Culture Category \\
\hline ST $19,0-20 \mathrm{~cm}$ & 3 cut nails (1820-1891); 2 unidentified nail shanks; 1 gray chert \\
& $\begin{array}{l}\text { lithic debris (non-cortical); } 1 \text { translucent gray chert lithic debris } \\
\text { (non-cortical) }\end{array}$ \\
& 2 wire nails (post-1891); 2 unidentified nail shanks; 1 grog- \\
ST $20,0-20 \mathrm{~cm}$ & tempered plain Caddo body sherd \\
& 1 wire nail (post-1895) \\
ST 22, 0-20 cm & 2 wire nails (post-1895) \\
ST 23, $0-20 \mathrm{~cm}$ &
\end{tabular}

The iron cut nails likely date to the period from ca. 1820-1891 (Wells 1998:Figure 8). They can also be associated with the cut nails and iron hinge found during earlier work in the same area of the site (Perttula and Nelson 2007a:13). They are not apparently part of the Nabedache Caddo occupation previously documented from the site. The wire nails (dating after ca. 1895, see Wells 1998; Adams 2002) 
suggest there was an even later historic use of the site.

No additional shovel tests were excavated at 41HO91B in March 2007. There were six surface finds (numbered Nos. 21-26). These new surface finds of Caddo ceramic sherds (Table 12) and one piece of lithic debris indicate that this Nabedache Caddo component at 41HO91B covers an estimated $92 \times 72 \mathrm{~m}$ area or approximately 6600 square meters (1.63 acres).

Table 12. Recovered archaeological materials from 41HO91B in March 2007 investigations.

\begin{tabular}{ll}
\hline Provenience & Material Culture Category \\
\hline Surface (No. 21) & 1 parallel brushed-incised body sherd; 1 plain body sherd \\
Surface (No. 22) & 1 plain base sherd; 1 plain body sherd \\
Surface (No. 23) & 1 horizontal incised rim sherd \\
Surface (No. 24) & 1 plain body sherd; 1 overlapping brushed body sherd \\
Surface (No. 25) & 1 plain and burnished body sherd \\
Surface (No. 26) & 1 overlapping brushed body sherd; 1 plain body sherd; \\
& 1 gray chert lithic debris (non-cortical) \\
\hline
\end{tabular}

The one piece of lithic debris is of a non-cortical gray chert from find No. 26. There are also six plain body or base sherds, including one well burnished body sherd from No. 25. The four utility ware decorated sherds in this collection are overlapping brushed $(n=2)$, parallel brushed-incised $(n=1)$, and horizontal incised $(n=1)$.

\section{$41 \mathrm{HO122}$}

Woldert (1935:207-208,211) had reported that a brass epaulet and a silver cane head had been found at $41 \mathrm{HO} 122$, along with human bones, probably all from a Historic Caddo burial. The site was located a short distance west of 41HO91, being situated on a "low sandy upland outlier adjacent to the uplands" in the San Pedro Creek valley (Erickson and Corbin 1996:27). Extensive shovel testing here defined a site area estimated to cover 1.58 acres, and with archaeological deposits ranging from $15-55 \mathrm{~cm}$ in thickness below the surface. Recovered artifacts from the work included four plain grog and sandy paste body sherds as well as a decorated elbow pipe bowl (Erickson and Corbin 1996:Figure 9g). They also collected seven pieces of lithic debris in the shovel testing.

This Caddo site is a short distance to the south-southwest of 41HO91B, in the same overgrown pasture as 41HO91B (Field). There is a low swale in the old field/pasture that apparently separates the two sites.

A total of 16 shovel tests excavated at $41 \mathrm{HO} 122$ in 2007 contained artifacts. Three separate surface artifact finds were also documented at the site (Figure 24). This site is estimated to cover a ca. $94 \times 78 \mathrm{~m}$ area or approximately 7330 square meters (1.8 acres).

A total of 44 artifacts were recovered from $41 \mathrm{HO} 122$ during the 2007 archaeological investigations, primarily ceramic vessel sherds (see Table 7). These account for 73 percent of the small artifact assemblage.

The ceramic vessel sherds include nine plain sherds and 23 decorated sherds $(\mathrm{P} / \mathrm{DR}=0.39)$. Engraved fine wares comprise 22 percent of the decorated sherd sample, with the remainder coming from utility ware vessels (see Table 8). The P/DR is 0.39 .

Two of the engraved sherds have hatched triangular elements that are usually found on Poynor Engraved vessels. Another has part of a vertical engraved panel (probably on a carinated bowl or a 


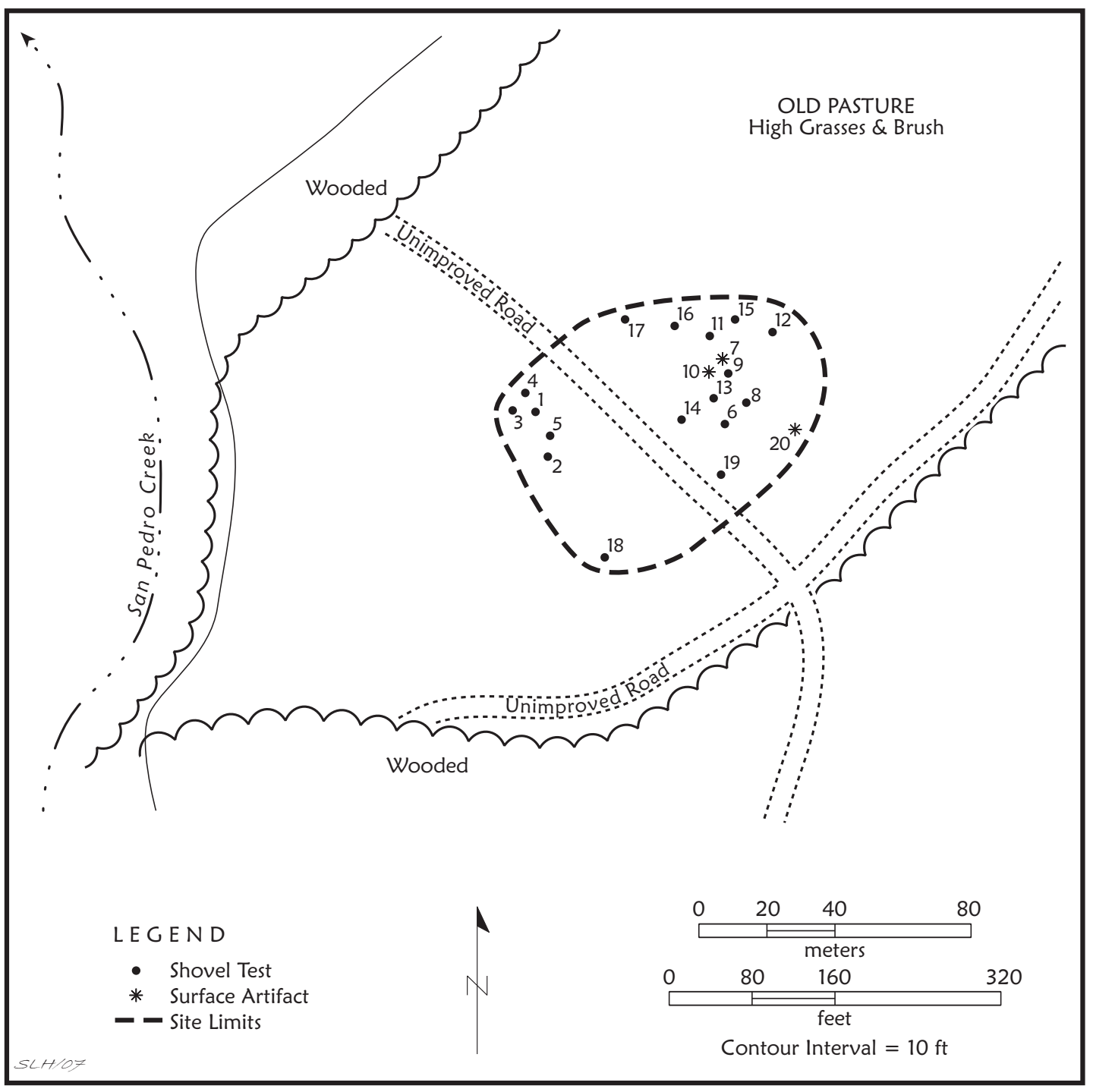

Figure 24. Map of 41HO122.

cylindrical-shaped Hume Engraved vessel, see Suhm and Jelks 1962: Plate 42a-e), while the other two have either a single straight engraved line or sets of closely-spaced parallel to curvilinear engraved lines (see Table 8).

Utility ware decorated sherds from $41 \mathrm{HO} 122$ are dominated by brushed vessel sherds, either with parallel (probably oriented vertically on the vessel body), overlapping, or opposed brushing marks (see Table 8). The only other decorated utility ware sherd has a single horizontal incised line on the vessel rim.

As an assemblage, the vessel sherds from $41 \mathrm{HO} 122$ are tempered primarily with grog, but with a significant number of the sherds also having crushed and burned bone temper inclusions (see Table 9). Crushed pieces of hematite were also occasionally added to the paste of vessels from this site, but with nowhere near the frequency of hematite tempering seen at 41HO91 and 41HO91B.

Vessel sherds with a clay paste (54.5 percent) are more common here than at the two components at 41HO91 (see Table 9), but sandy paste clays were still regularly used by the Nabedache Caddo potters. Vessels at this site were usually fired in a reducing environment (71.4 percent), as with the other Nabedache Caddo pottery recovered at sites at Mission Tejas State Park. 
One ferruginous sandstone mano fragment (ground and smoothed on one side) was recovered in ST 122-9 (0-30 cm bs). The six pieces of lithic debris includes dark gray chert $(\mathrm{n}=1)$, gray chert $(\mathrm{n}=2)$, and quartzite $(\mathrm{n}=2)$, as well as a single piece of honey-colored chert (ST 122-14, 0-30 cm bs) that may be a piece of knapping debris from the resharpening/reshaping of a gunflint. Both pieces of quartzite have cortical remnants, implying the on-site reduction of quartzite pebbles and the on-site manufacture of quartzite tools from local stream gravel sources.

Artifacts of European or American manufacture include a cut nail from ST 122-5 $(0-10 \mathrm{~cm})$ and three other pieces of iron from the southwestern part of 41HO122. One is an unidentifiable iron fragment, another (ST 122-1, 0-5 cm bs) is a poorly preserved frizzen from a probable $18^{\text {th }}$ century French musket (Jay Blaine, 2007 personal communication; see Jelks 1967:Figure 28a-d), while the third piece (ST 122$4,0-10 \mathrm{~cm}$ bs) is a $\mathrm{U}$-shaped iron piece of colonial-age horse trappings, possibly a piece of a bridle.

A single piece of burned animal bone (ST 122-14, 0-30 cm) from one shovel test indicates that some evidence of animal subsistence practices is preserved at $41 \mathrm{HO} 122$.

No Colonial-era metal or other trade goods were found at $41 \mathrm{HO} 122$ during the second round of metal detecting/shovel testing in March 2007, although an $18^{\text {th }}$ century musket frizzen and an iron piece of horse trappings were found earlier in the western part of the site by Perttula and Nelson (2007a:18). Seventeen new shovel tests (ST 22-24, ST 26-34, and ST 36-40), do contain, however, archaeological deposits and material culture remains from the Nabedache Caddo occupation (Figure 25 and Table 13), and two ceramic sherds were found on the surface (No. 35 and No. 41).

Table 13. Recovered archaeological materials at $41 \mathrm{HO122}$ during March 2007 investigations.

\begin{tabular}{|c|c|}
\hline Provenience & Material Culture Category \\
\hline Surface (No. 35) & 1 parallel brushed body sherd \\
\hline Surface (No. 41) & 1 overlapping brushed body sherd \\
\hline ST $22,0-20 \mathrm{~cm}$ & 1 straight line incised body sherd \\
\hline ST $23,0-20 \mathrm{~cm}$ & 1 plain body sherd \\
\hline ST $24,20-40 \mathrm{~cm}$ & $\begin{array}{l}1 \text { petrified wood Perdiz arrow point fragment; } 1 \text { parallel } \\
\text { brushed body sherd }\end{array}$ \\
\hline ST $26,0-20 \mathrm{~cm}$ & $\begin{array}{l}1 \text { honey-colored chert lithic debris (non-cortical); } 1 \text { parallel } \\
\text { brushed body sherd; } 1 \text { overlapping brushed body sherd }\end{array}$ \\
\hline ST $27,0-20 \mathrm{~cm}$ & 1 overlapping brushed body sherd \\
\hline ST $28,0-20 \mathrm{~cm}$ & 1 plain body sherd \\
\hline ST $29,0-20 \mathrm{~cm}$ & 1 plain body sherd \\
\hline ST $30,0-20 \mathrm{~cm}$ & 1 parallel brushed body sherd \\
\hline ST $31,0-20 \mathrm{~cm}$ & 1 plain body sherd \\
\hline ST $32,0-20 \mathrm{~cm}$ & 1 Patton Engraved body sherd \\
\hline ST $33,0-20 \mathrm{~cm}$ & 1 plain body sherd \\
\hline ST $34,0-20 \mathrm{~cm}$ & 1 dark gray chert lithic debris (non-cortical) \\
\hline ST $36,0-20 \mathrm{~cm}$ & 1 plain body sherd \\
\hline ST $37,0-20 \mathrm{~cm}$ & 1 overlapping brushed body sherd \\
\hline ST $38,0-20 \mathrm{~cm}$ & 1 Patton Engraved body sherd \\
\hline ST $39,0-20 \mathrm{~cm}$ & 1 plain base sherd \\
\hline ST $40,0-20 \mathrm{~cm}$ & 1 parallel brushed body sherd; 1 Patton Engraved body sherd \\
\hline
\end{tabular}




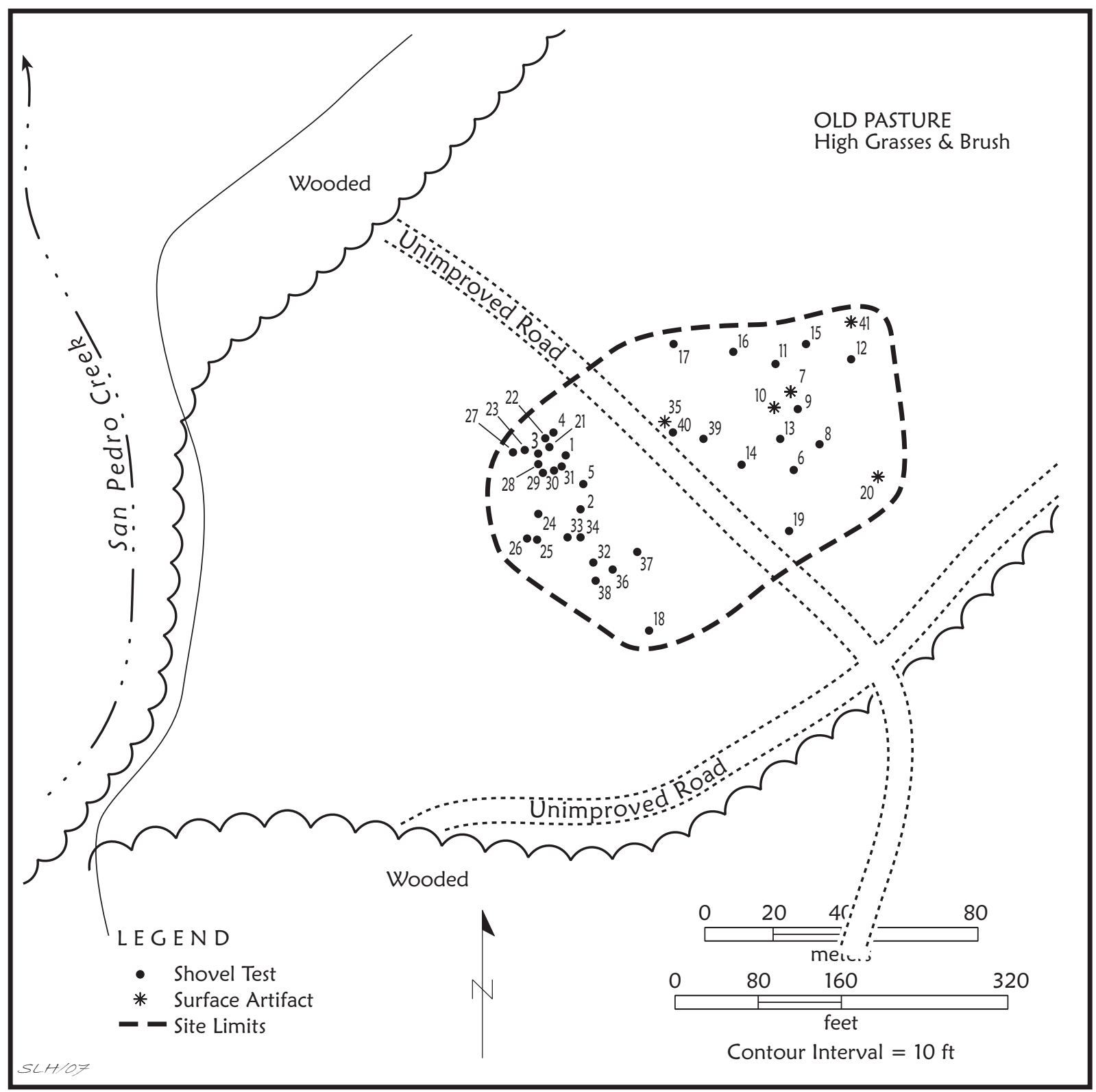

Figure 25. Site Map of 41HO122.

With these new surface and shovel testing finds, $41 \mathrm{HO} 122$ is estimated to cover a ca. $100 \mathrm{x} 78 \mathrm{~m}$ area or approximately 7800 square meters (1.93 acres).

Three of the recovered artifacts are lithic (see Table 13), including a piece of dark gray chert lithic debris (ST 34), a piece of honey-colored chert lithic debris (ST 26), and a fragment of a bifaciallyknapped Perdiz arrow point made from petrified wood (ST 24).

The remainder of the artifacts from $41 \mathrm{HO} 122$ are ceramic vessel sherds $(\mathrm{n}=20) ; 13$ of the 20 sherds are decorated. Combining these sherds with the sherd sample reported earlier by Perttula and Nelson (2007a:16; see above) from the site, the plain: decorated sherd ratio of the larger sample $(n=52)$ is 0.44 , consistent with an Historic Caddo Allen phase occupation. 
Nine of the decorated sherds are from brushed utility wares, and a tenth is a body sherd with a single straight incised line on it. The other three sherds have triangular tick-marked straight lines from Patton Engraved bowls (Suhm and Jelks 1962:Plate 59d-f). Patton Engraved is the principal engraved fine ware in Allen phase components in the Neches and Angelina River basins.

\section{$41 \mathrm{HO147}$}

$41 \mathrm{HO} 147$ was found on a sandy rise at the edge of the San Pedro Creek floodplain, north of 41HO91. Site size was estimated at 0.62 acres. Erickson and Corbin (1996:30) mentioned that a Mr. and Mrs. Howard Moore had previously collected Caddo pottery sherds and glass trade beads when the site was cleared for a pasture. During the Erickson and Corbin (1996) work (consisting of 40 shovel tests), they recovered archaeological materials from $45-68 \mathrm{~cm}$ bs, including two plain body sherds, one brushed sherd, and three pieces of lithic debris.

Minimal archaeological information was obtained from 41HO147 during both 2007 investigations. This was primarily the result of the very thick underbrush and grass at this site area, as well as the waterlogged sediments due to a heavy rain one night before we were able to work at the site.

In the area of $41 \mathrm{HO} 147$ that apparently corresponds to the site location based on UTMs provided by Erickson and Corbin for their completed site form, we were not able to locate any archaeological materials (including metal) in the four shovel tests excavated there. Ranging farther to the east along the edge of the overgrown pasture, where a Caddo pottery sherd was visible on the surface, we were able to locate archaeological materials in limited shovel testing. Three shovel tests here (out of a total of seven shovel tests) contained aboriginal ceramic and lithic artifacts, but no artifacts definitive of a Historic Nabedache Caddo settlement. These three shovel tests delimit an area covering approximately 1500 square meters ( 0.4 acres), although we suspect the site was much bigger than we were able to establish in our limited investigations.

Recovered artifacts from $41 \mathrm{HO} 147$ in the first round of work included two sherds and three pieces of lithic debris (see Table 7). One of the sherds was found on the surface, and it is a grog-tempered base sherd. The other sherd (ST 2, 0-20 cm bs) is from a carinated bowl that has a horizontal and diagonal engraved motif marked by hatched triangles at the intersection of the horizontal and diagonal lines. This decorated sherd is from a Poynor Engraved vessel. Such vessels were made and used in both Frankston (ca. A.D. 1400-1650) and post-A.D. 1650 Allen phase times by the Caddo (see Kleinschmidt 1982), but by itself does not constitute evidence for a Historic Nabedache Caddo settlement at 41HO147.

Two shovel tests were excavated at the site in March 2007. Lithic debris was recovered in both from $50-70 \mathrm{~cm}$ bs in a buried A-horizon (Table 14). The top of the buried A-horizon is at $40 \mathrm{~cm}$ bs in the two shovel tests.

Table 14. Recovered archaeological materials from March 2007 investigations at $41 \mathrm{HO} 47$.

\begin{tabular}{ll}
\hline Provenience & Material Culture Category \\
\hline ST 6, 60-70 cm & 1 lithic debris, non-cortical, "sugary" quartzite \\
ST 7, 50-60 cm & 1 lithic debris, non-cortical, gray chert \\
\hline
\end{tabular}

The two positive shovel tests - and the identification of a buried A-horizon - confirm Erickson and Corbin's (1996:30) suspicion that the archaeological deposits at the site are buried. There is no indication that the archeological deposits have been significantly impacted or destroyed (contra Erickson and Corbin 1996:30). Unfortunately, the recovered artifacts shed no light on whether 41HO147 was occupied during historic times by the Nabedache Caddo. 


\section{HO211, Nabedache Blanco}

The Nabedache Blanco site is located on a probable alluvial fan and lower toe slope (230-240 feet amsl) (Figure 26) immediately adjacent to the San Pedro Creek floodplain. The landform has an overstory of pines and hardwoods, with a low understory of vines, brush, cane, and sparse grasses. Surface visibility is poor, at $0-10$ percent, and no artifacts were noted on the surface across the site.

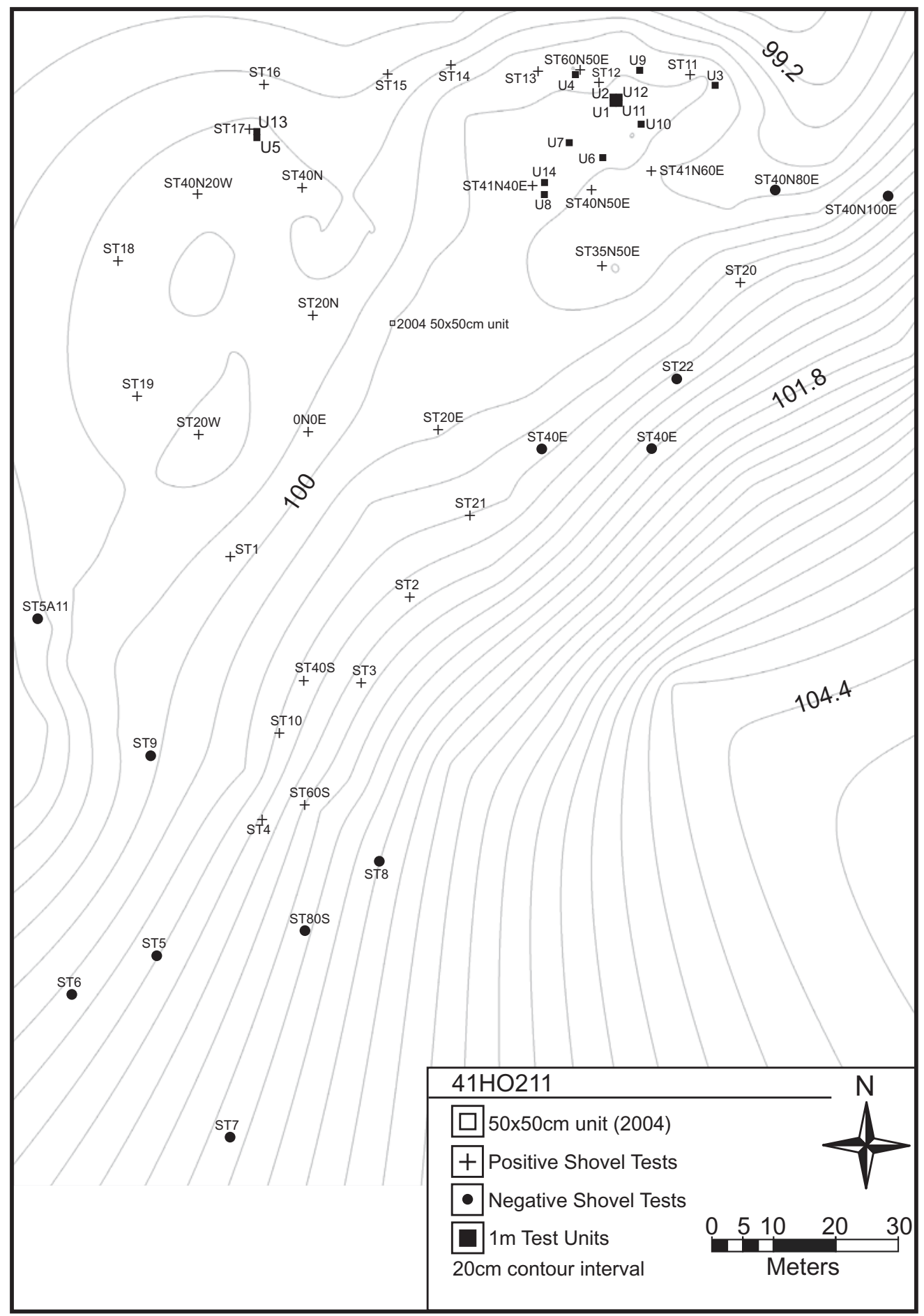

Figure 26. Map of the Nabedache Blanco site (41HO211). 
Based on shovel testing and metal detector surveys (Perttula and Nelson 2006), the Nabedache Blanco site covers approximately 10,300 square meters (ca. 2.5 acres). Most of the site is on relatively flat-lying land adjacent to, and ca. $1 \mathrm{~m}$ above, the San Pedro Creek floodplain, while some archaeological deposits occur along the base of a ridge toe slope ca. $1 \mathrm{~m}$ above the lower-lying parts of the site (see Figure 26). The low-lying parts of the site are separated by a swale, and the westernmost part of it (i.e., in the area of Units 5 and 13) is covered in tall cane. It also has different and thicker sediments than the eastern part of the site (i.e., in the area of the remainder of the units). None of the sediments appear to be alluvial in character, but are instead probably primarily the product of colluvial deposition from the nearby and steep upland slope (see Figure 26). However, the fact that the thickest deposits occur along the margins of the landform closest to the San Pedro Creek floodplain - and farthest from the base of the upland slope-suggests that some alluvial deposits contributed to the formation of the sediments on the Nabedache Blanco site.

Twenty-two shovel tests were excavated across the site, and almost all of the lower-lying portions of it were systematically examined by metal detectors (Perttula and Nelson 2006:Figure 18). The findings from the shovel tests and the metal detecting indicated that important archaeological deposits containing aboriginal ceramic sherds, lithic artifacts and tools, and $17^{\text {th }}$ and $18^{\text {th }}$ century metal (as well as glass beads, as the fine-screened columns from the units showed) (Table 15), were concentrated in two parts (Areas A and B) of the low-lying area. Very little archaeological materials occurred in the lower toe slope deposits at the base of the steep upland slope. The hand-excavated units were accordingly concentrated in Areas A and B.

Table 15. Material culture remains from the Nabedache Blanco (41HO211), Nabedache Azul (41HO214), and Butler Branch (41HO216) sites.

\begin{tabular}{llll}
\hline Artifact category & $41 \mathrm{HO} 211$ & $41 \mathrm{HO} 214$ & $41 \mathrm{HO} 2$ \\
\hline Aboriginal artifacts & & & 2 \\
Plain sherds & 22 & 50 & 17 \\
Decorated sherds & 70 & 172 & 1 \\
Woodland period & 2 & 5 & - \\
$\quad$ sandy paste sherds & $4 / 1$ & - & 1 \\
Ceramic pipe sherds & 3 & - & $6^{*}$ \\
Burned clay & $7 \wedge *$ & 2 & 1 \\
Chipped stone tools & 2 & 1 & 402 \\
Ground stone tools & 553 & 25 & \\
Lithic debris & & &
\end{tabular}

\section{European artifacts}

\begin{tabular}{llll} 
Glass beads & 10 & 18 & - \\
Majolica sherds & - & 1 & - \\
Gunflints & 1 & 3 & - \\
Gun parts and ammunition & 2 & 5 & - \\
Other Colonial era metal & 3 & 17 & 430 \\
\hline Totals & 676 & 299 &
\end{tabular}

$\wedge=$ arrow point in assemblage; $*=$ dart points in assemblage 
The metal detector hits are clearly clustered in Area A on the eastern part of the landform, with a few widely-scattered hits in Area B (Figure 27). All of the metal detector hits in Area B were of late $19^{\text {th }}-20^{\text {th }}$ century metal, including barbed wire, pieces of wire, and shotgun shells. In Area A, a ca. 240 square meter area had metal detector hits with a Spanish spur fragment (MD 4), a French-style iron hoe (MD 1), and a possible iron strike-a-light in MD 14 (see Figure 27). All these came from less than $20 \mathrm{~cm} \mathrm{bs}$ in Zone 2 sediments.

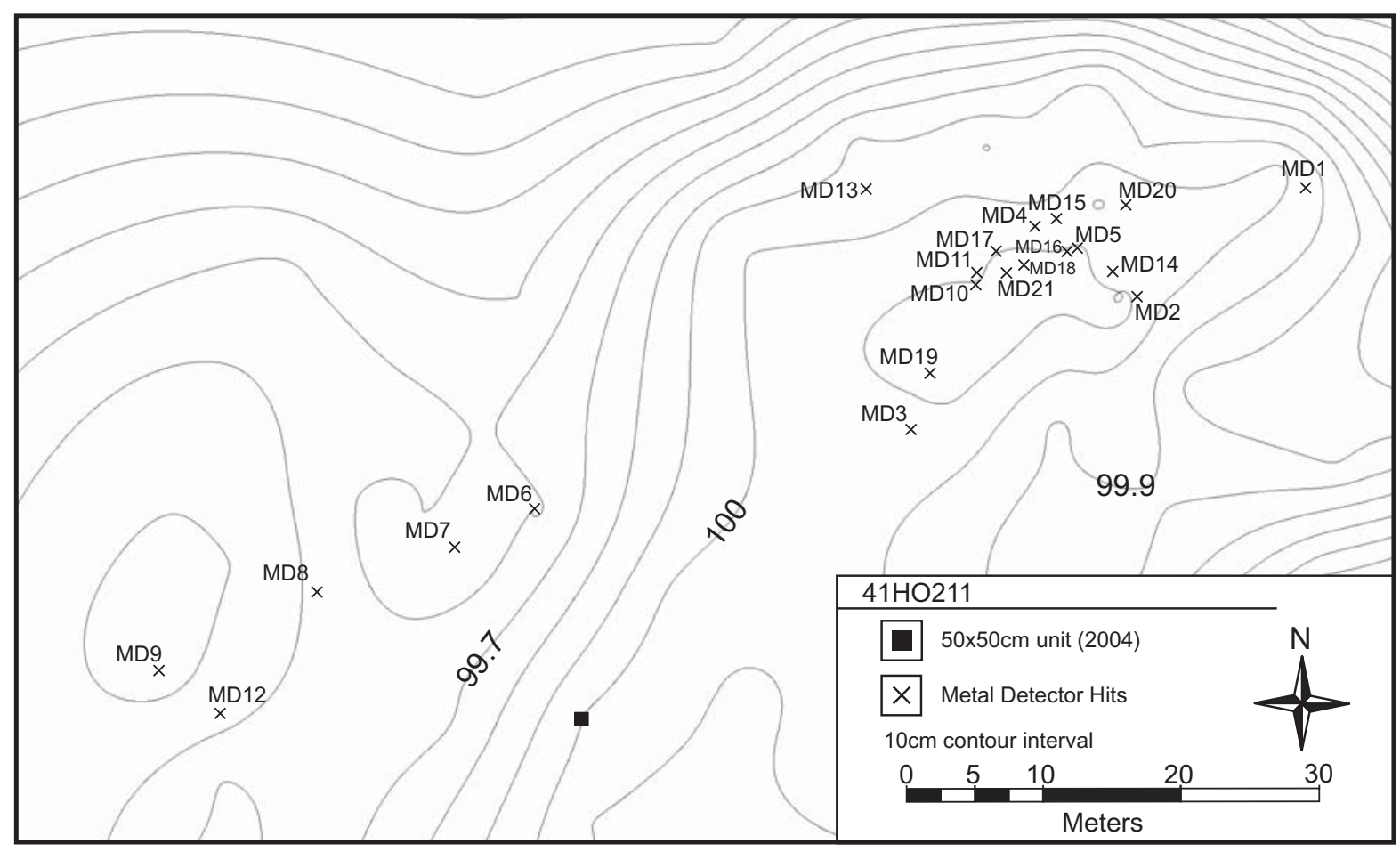

Figure 27. Distribution of metal detector hits at the Nabedache Blanco site (41HO211).

Aboriginal Caddo ceramic sherds are concentrated in the same part of the site (Perttula and Nelson 2006:Figure 20), although sherd densities reach only as high as 11 sherds per square meter (Unit 6). Sherds from Patton Engraved, Poynor Engraved, Bullard Brushed, La Rue Neck Banded, Maydelle Incised, and cf. Hume Engraved have been identified at both the Nabedache Blanco as well as the Nabedache Azul site (41HO214). The only pipe sherds recovered in the work (all apparently from a single elbow pipe) came from Unit 14 in Area A. In Area B, sherds from Unit 5 and 13 occur at a density of 7-13 sherds per square meter. One sherd was also found in a shovel test (ST 4) on the lower toe slope part of the site.

There is a wider distribution of lithic artifacts on the site, but lithic tools and pieces of lithic debris are best represented in Areas A and B on the lower-lying part of the site. In the 1 x 1 m units, lithic debris densities ranged from 2-70 pieces per square meter (with the highest densities in Unit 1, 6, 7, and 14), with densities between 68-91 pieces per square meter in the Area B units. Three shovel tests on the lower toe slope each had 1 piece of lithic debris (ST 2, 3, and 21, see Figure 26).

European trade goods are concentrated in Area A of the site (see Table 15). This not only includes the previously mentioned metal artifacts (see Figure 26), but glass beads and a few gun parts as well. One gunflint was recovered in Area B (Unit 5), the same area that we recovered a Turney arrow point, and Galan (2003) had previously reported the recovery of a Cuney arrow point from this same area. 
The majority of the 10 glass beads from Area A of the site ( 80 percent) were found in the fine-screen columns, as was a piece of lead sprue. Larger pieces - such as a lead ball in Unit 1 (30-40 cm) and the few larger beads - were recovered in either the 1/-4-inch screen matrix or in the metal detecting effort. Less than 9 percent of the fine-screen samples contained European trade goods. Of the 16 recovered artifacts of European derivation, 81 percent were found in the upper $30 \mathrm{~cm}$ of the archaeological deposits (in Zones 1 and 2), but they did occur as deep as $40-50 \mathrm{~cm}$ bs in a Unit 2 fine-screen column (Zone 3 ).

Aboriginal ceramic sherds and lithic artifacts occur throughout the archaeological deposits, and fire-cracked rock is found only in Zone 3 and 4 sediments. A Woodland period dart point was found at a comparable depth as Zone 3 or 4 in ST 19 in Area B. Two non-tempered Woodland period sandy paste sherds (Goose Creek Plain, var. unspecified) were also found in Area B. Taken together with the evidence of the deeper sediments containing fire-cracked rock, this suggests that the Nabedache Blanco site was first occupied at least by Woodland period times (ca. 500 B.C.-A.D. 800; see Rogers et al. [2001:16-22] and Story [1990:277-303] for a summary of Woodland period archaeology in East Texas).

The main occupation of the site took place after ca. A.D. 1650 - based on the decorated aboriginal ceramic sherds and the radiocarbon dates - and this occupation was concentrated on the northern part of the lowest-lying part of the landform overlooking the San Pedro Creek floodplain. During the course of this Caddo occupation, the residents of the site obtained European trade goods (but still in low frequencies), including beads, gun parts, and a metal hoe, strike-a-light, and a Spanish spur.

The two calibrated radiocarbon dates obtained from the Nabedache Blanco site are on charred hickory nutshells from Unit 5/13 (20-30 cm bs) and Units 1/2/12 (20-30 cm bs). At 2 sigma, the first calibrated sample has age ranges of A.D. 1510-1600 and A.D. 1620-1950, with a calibrated intercept of A.D. 1660 (Beta-206839). The second date is slightly younger, with a 2 sigma calibrated age range of A.D. 16601950 (Beta-206840), and with the oldest intercept being A.D. 1680 (other intercepts are AD 1730, 1810, 1930, and 1950). Both dates and the intercepts suggest that the Nabedache Blanco site was occupied early in the Allen phase.

\section{HO214, Nabedache Azul}

The Nabedache Azul site is on a colluvial bench (245-250 feet amsl) along a lower upland slope above the San Pedro Creek floodplain. A deep gully cuts across the bench, and marks the northern extent of the site (Figure 28). The main part of the site has a slight slope from east to west, where it flattens out at its far western extent where archaeological materials apparently extend onto the San Pedro Creek floodplain.

From shovel testing and metal detecting hits by Perttula and Nelson (2006), the Nabedache Azul site is estimated to cover 4400 square meters ( 1.1 acres), measuring $83 \mathrm{~m}$ east-west and a maximum of $53 \mathrm{~m}$ in width. Shovel testing conducted by Cooper and Cooper (2005:Figure 16) suggests that the site may extend to the fence line (and beyond) at the southern extremes of the site (see Figure 28), although little archaeological material was found in that area. The metal detecting effort covered the colluvial bench and a portion of the northern part of the site, all west of the gully. Previous investigations by Cooper and Cooper (2005:37) had already indicated that there were no archaeological deposits on the north side of the gully. The metal detecting extended to the fence line on the south, and some distance east upslope along the bench.

There were a number of metal detector hits in the central part of the site, mostly concentrated in a ca. 1000 square meter area of the colluvial bench. The one brass tinkler recovered by Cooper and Cooper (2005) from the Nabedache Azul site also came from this same area (Figure 29). Most of the metal in this central area appears to be from a historic Nabedache Caddo occupation, and included $18^{\text {th }}$ century gun parts, lead balls, lead sprue, iron knifes, iron kettle fragments, and a rolled piece of brass. Twenty-three 


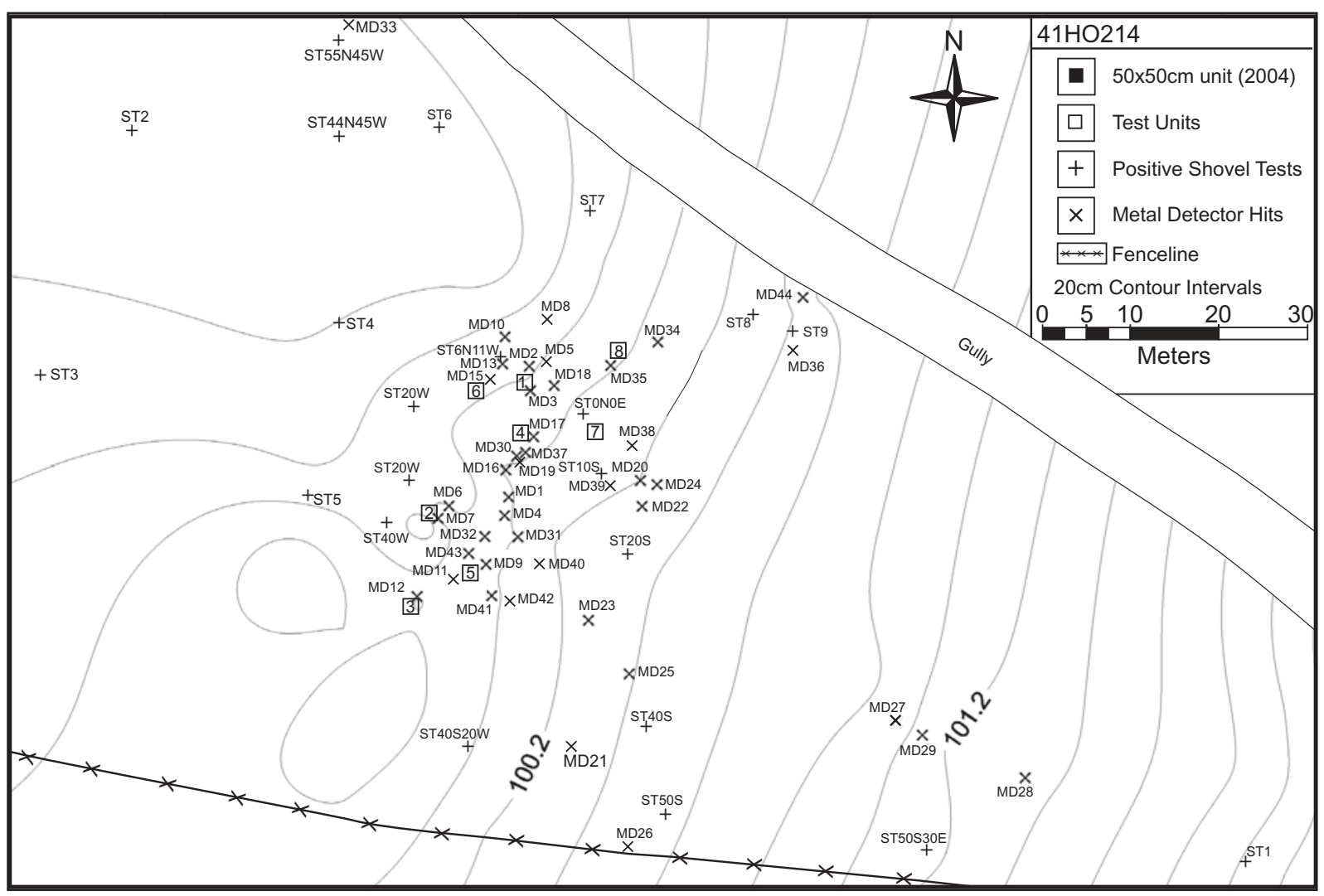

Figure 28. Map of the Nabedache Azul site (41HO214).

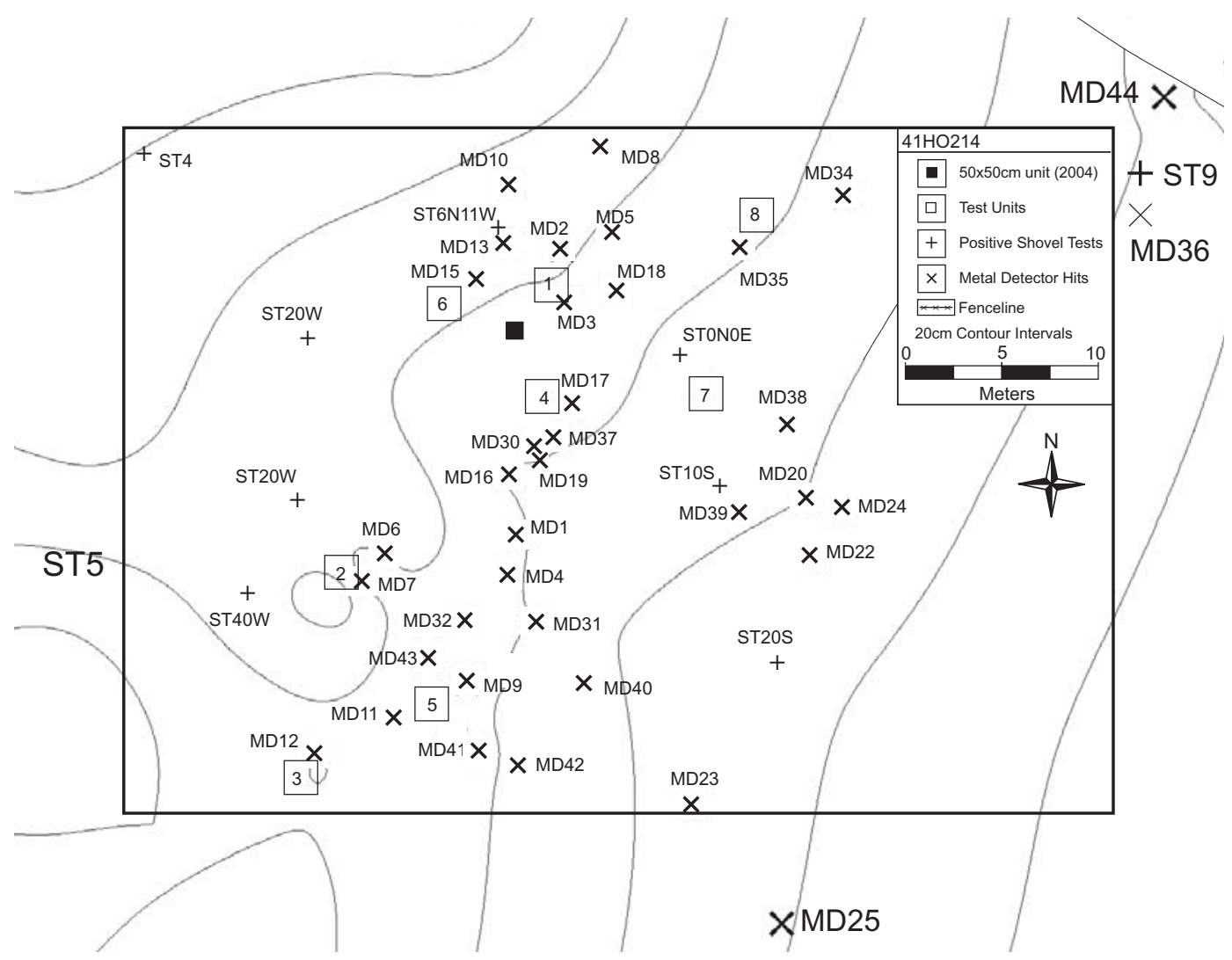

Figure 29. Metal detector hits at the Nabedache Azul site. 
metal artifacts of apparent $18^{\text {th }}$ century age were recovered from the metal detecting work (see Table 15). Glass beads and gunflints were also found in this area in the $1 \times 1 \mathrm{~m}$ hand-excavated units, along with one sherd of majolica from Unit 5.

There is a ca. $10 \mathrm{~m}$ diameter area in this central area where European metal artifacts are notably absent. What might have created this spatial discontinuity in the distribution of metal artifacts during the historic Caddo component? Further investigations - including remote sensing-would be in order to examine the character of the archaeological deposits in this area (since no shovel tests or hand-excavated units were excavated there). Nevertheless, we suggest that this $10 \mathrm{~m}$ diameter spatial anomaly may be accounted for by the likelihood that a structure stood there during the occupation, and broken metal and other artifacts were discarded by the Caddo around it, rather than within it.

The European trade goods were most commonly recovered from $0-20 \mathrm{~cm}$ bs ( 87 percent) in Zone 1 and 2 sandy loam sediments. The remainder came from 20-30 cm bs. More than 94 percent of the glass beads were found in the fine-screen columns, but the only other European trade good recovered in the fine-screen columns was a piece of lead sprue with a cut-out from a lead ball.

Twentieth-century metal, including a few wire nails and 12-gauge shotgun shells, were found in the metal detecting hits to the east some 10-50 m from the historic Nabedache Caddo component. This is on the eastern side of an old and shallow road bed that cuts across the landform. Perhaps a more recent farm outbuilding stood in this area at one time.

Aboriginal Caddo lithic and ceramic artifacts are concentrated in the same area as the European trade goods, namely on the western edge of the colluvial bench. Lithic artifacts of any kind are uncommon at the Nabedache Azul site (see Table 15). Except for one piece of lithic debris from ST 2, the remainder of the lithic artifacts come from hand-excavated units and metal detector hits in the central part of the site. Lithic debris densities in the $1 \times 1 \mathrm{~m}$ units ranged from only 1-5 pieces per square meter. Ceramic sherds have a broader distribution, based on the recovery of sherds in shovel testing (ST 2 and ST 4) along the margins of the San Pedro Creek floodplain (see Figure 28) as well as closer to the gully. The highest densities of sherds in the $1 \times 1 \mathrm{~m}$ units and the metal detector hits are in the same area as the distribution of European trade goods.

The highest sherd densities in the controlled hand excavations are in Units 1, 4, and 6 (see Figure 28). There, sherds occur at a density of 23-37 per square meter, much higher than at the Nabedache Blanco site. In the remainder of the central area, sherd densities are only 5-19 per square meter.

Found at the Nabedache Azul site with the tempered historic Nabedache Caddo ceramics are five non-tempered sandy paste Woodland period sherds (see Table 15). These include one sherd each from MD 32, Unit $3(20-25 \mathrm{~cm})$, Unit $4(0-10 \mathrm{~cm})$, Unit $5(20-30 \mathrm{~cm})$, and Unit $7(0-10 \mathrm{~cm})$.

The Woodland period sherds are the only archaeological indication that the Nabedache Azul site was used prior to the Nabedache Caddo settlement in the $18^{\text {th }}$ century. This latter Caddo component is the principal and primary occupation represented at the site, although there is a late $19^{\text {th }}-20^{\text {th }}$ century veneer of metal artifacts to the east of the historic Caddo occupation. Radiocarbon samples from the Nabedache Azul site came from charred hickory nutshells found in Unit $6(20-25 \mathrm{~cm}$ bs) and from the organics inside the paste of a Patton Engraved sherd (with a triangular tick mark decorative element) found in Unit $6(0-10 \mathrm{~cm} \mathrm{bs})$.

The first date (Beta-206841) has a 2 sigma age range of A.D. 1660-1950, with intercepts of A.D. 1680, 1740, 1800, 1930, and 1950. The other date - from the Patton Engraved sherd-has a 2 sigma age range of A.D. 1460-1650, with calibrated intercepts of A.D. 1520, 1580, and 1630 (Beta-206842). Both calibrated dates leave open the possibility that the Nabedache Azul site was occupied to some extent 
early in the Allen phase (or even earlier), as well as later (when the majority of the European trade goods were obtained). Additional radiocarbon dates and/or thermoluminescence dates are likely necessary to better resolve the absolute age and duration of the occupation(s) at the Nabedache Azul site.

Shovel testing for the NPS in 2010 in the McLean tract, on the east side of the San Pedro Creek valley and just south of Mission Tejas State Park, identified Historic Caddo archaeological deposits in only one area, despite the occurrence of alluvial rises, alluvial fan deposits, and other landforms considered to have the potential to contain Historic Caddo archaeological sites. This area is the southernmost part of the Nabedache Azul site (41HO214), one of the Historic Nabedache Caddo habitation sites (Perttula and Nelson 2006:46-54) that is on Texas Parks and Wildlife Department lands as well as private property. The site is on a colluvial bench (245-250 feet amsl) (Figure 30).

The shovel tests found two plain bone-tempered Caddo pottery body sherds (5.6-5.9 $\mathrm{mm}$ ) between $0-20 \mathrm{~cm}$ bs in ST 4 and ST 5. These are from two separate vessels fired in a reducing environment and cooled in the open area.

A metal detector was employed during the 2010 archaeological survey of the McLean tract; previous investigations at the Nabedache Azul site had recovered $18^{\text {th }}$ century lead balls, lead sprue, an iron gun cock, a brass butt plate finial, cast iron kettle fragments, a brass tinkler, possible hand wrought nails, iron knife blade fragments, a brass trade kettle piece, a hand-forged iron band, an undecorated cupreous button, and various iron strips (Perttula and Nelson 2006:94-101). However, the 2010 metal detector investigations only recovered $20^{\text {th }}$ century metal artifacts (from ST 1-8)-such as a cotter pin, barbed wire, an iron plow part, a hitch pin, and pieces of wire. These are apparently a continuation of a concentration of $20^{\text {th }}$ century metal defined near the Mission Tejas State Park fence line in Perttula and Nelson's (2006:Figure 26) work at the Nabedache Azul site.

\section{HO216, Butler Branch}

The Butler Branch site is situated on a low rise (ca. 230-232 feet amsl) in the San Pedro Creek floodplain (Figure 31). The current channel of the creek runs along the site's northern edge. The site area is covered with tall canes, grasses, and hardwood trees. Perttula and Nelson (2006) systematically metal detected a ca. 1000 square meter area of the rise, but no $17^{\text {th }}$ or $18^{\text {th }}$ century metal artifacts were recovered in this effort. There were only two metal detector hits within this area, and in one of the hits (MD 1), no metal artifacts were actually recovered in the excavations at the hit spot.

Lithic artifacts (especially lithic debris) are broadly distributed across the Butler Branch site, being recovered in three of the five shovel tests, one metal detector hit, and all of the $1 \times 1 \mathrm{~m}$ units (see Table 15). These materials are particularly common on the southern part of the rise, where densities of more than 102-168 pieces per square meter are documented. On the northern part of the rise, lithic debris densities were 56 pieces per square meter in Unit 3.

Ceramic sherds were recovered only in three of the $1 \mathrm{x} 1 \mathrm{~m}$ units. They were most common in Unit 1 and 4, with densities of 6-10 sherds per square meter, on the southern part of the rise. In Cooper and Cooper's (2005:48) work at the site, 33 of the 34 recovered sherds came from a 50 x $50 \mathrm{~cm}$ unit. This 50 x $50 \mathrm{~cm}$ unit was located just to the east of Units 1 and 4 (see Figure 31), and it is likely (based on the descriptions of the sherds and Cooper and Cooper [2005: Figure 26]) that many of the sherds we recovered in Units 1 and 4 are part of the same vessel sections recovered during the earlier work.

This small site (less than 0.3 acres) contains evidence of stratified and buried archaeological deposits along the San Pedro Creek channel. The uppermost prehistoric component is a prehistoric Caddo occupation that Cooper and Cooper (2005) thought dated to Middle and/or Late Caddo periods. A radiocarbon date on one of the recovered brushed sherds $(28 \mathrm{~cm}$ bs in Unit 2) from this component has a 




Figure 30. Shovel test locations in the McLean tract, San Pedro Creek, Houston County, Texas. ST 1-10 are in the area of the Nabedache Azul site (41HO214). 


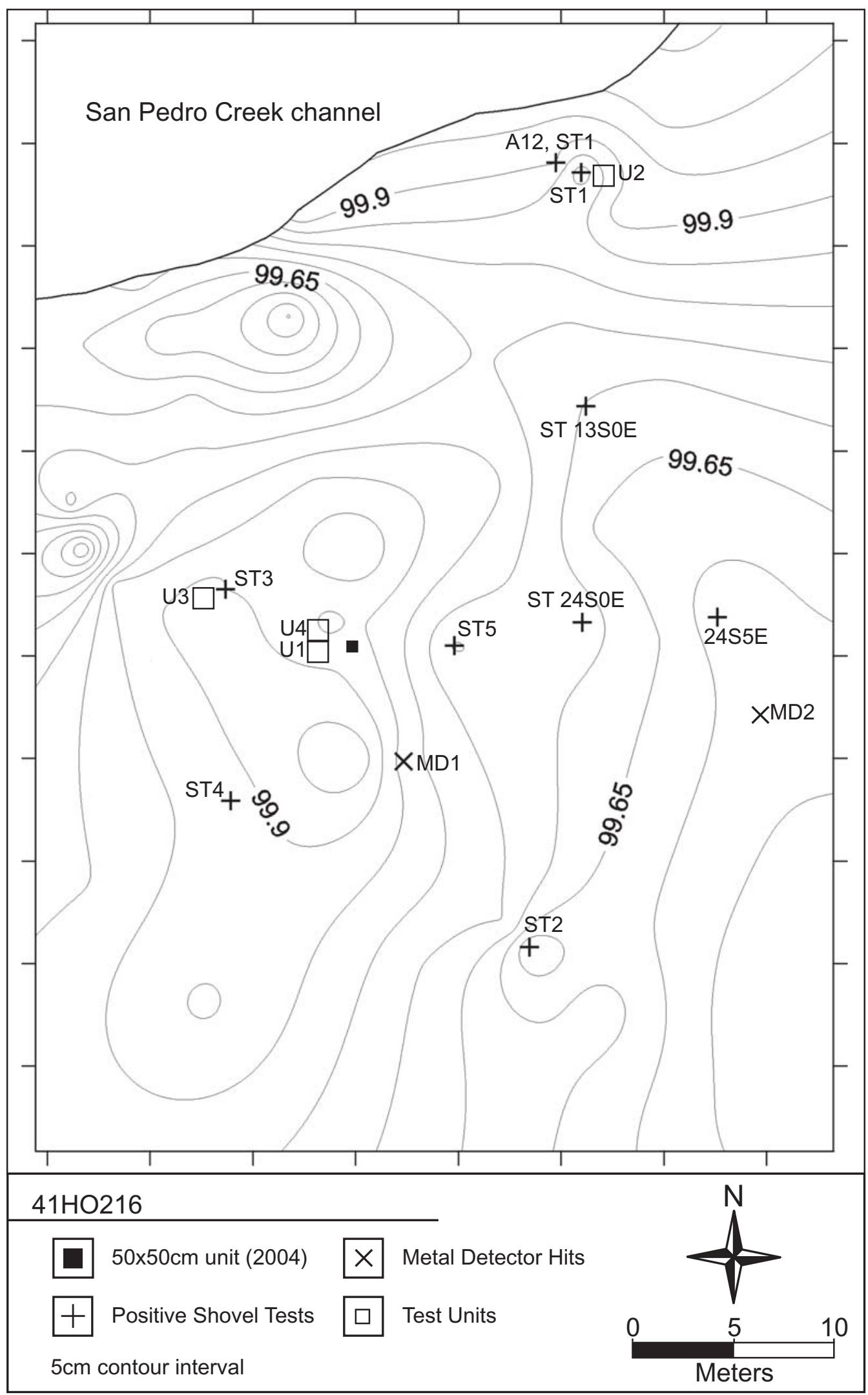

Figure 31. Map of the Butler Brach site (41HO216). 
2 sigma calibrated age range of A.D. 1200-1290 (Beta-206844), with a calibrated intercept of A.D. 1270. Below the Caddo occupation is a pre-A.D. 700 Woodland period occupation marked by higher densities of lithic debris, dart point fragments, and fire-cracked rocks. Charred hickory nutshells from $60-70 \mathrm{~cm}$ bs in Unit 2 date from A.D. 400-660 at 2 sigma (Beta-206843), with a calibrated intercept of A.D. 550. This corroborates the estimated earlier age of the deeper prehistoric archaeological deposits buried on the small rise.

\section{Decorated Ceramic Vessel Sherd Collection, Mission Tejas State Park Area, Houston County, Texas}

\section{Timothy K. Perttula, Mark Walters, and Bo Nelson}

At the request of John Tatum, Park Ranger for Mission Tejas State Park in Houston County, Texas, we examined in March 2007 a large collection of prehistoric and early historic Caddo ceramic vessel sherds from the Mission Tejas State Park and San Pedro Creek area of Houston County, Texas. These vessel sherds were collected over a number of years by Plev Cutler and his family in the Mission Tejas State Park area.

The decorated ceramic vessel sherds $(n=619)$, and the one blade gunflint, in this collection are indicative of occupation by the Caddo Indian peoples from as early as ca. 500 B.C. to at least sometime in the late $18^{\text {th }}$ century (if not later). The principal Caddo occupation of the San Pedro Creek area as shown by the Cutler collection was sometime after ca. A.D. 1650.

The earliest pottery in the collection is represented by about 10 plain sandy paste sherds made by ancestral Caddo Indian people between about 500 B.C. and A.D. 800. There is also one incised and rocker-stamped body sherd made around A.D. 100-400 that may have been part of a vessel that came from peoples living along the Red River or in the lower Mississippi Valley in Louisiana. The same sandy paste pottery is found over much of East Texas from the Neches River east and north to the Sabine River, as well as across a good part of Southeast Texas, all the way to the Gulf Coast. This is the earliest pottery made in East Texas and is identified as Bear Creek Plain or Goose Creek Plain, var. unspecified (see Story 1990). The culture that made this pottery is called Mossy Grove by archaeologists, and the Mossy Grove culture groups were relatively mobile hunter-gatherers who used pottery vessels to heat and cook plant and animal foods, including seeds, nut meats, and grains.

One Weches Fingernail Impressed sherd - with horizontal incised lines on the rim that separated rows of half circle-shaped fingernail impressions - in the collection is evidence of a very limited Caddo use of the San Pedro Creek area between ca. A.D. 900-1200 (Table 16). This is during the heyday of the Caddo settlement at the regionally important George C. Davis site (41CE19), otherwise known as the Caddo Mounds State Historic Site a few miles east of Mission Tejas State Park situated on a large alluvial terrace of the Neches River.

Table 16. Caddo decorated sherds in the Cutler collection from San Pedro Creek.

Engraved ( $\mathrm{n}=44)$

Patton Engraved $(\mathrm{n}=14)$

Hume Engraved $(\mathrm{n}=2)$

Poynor Engraved $(\mathrm{n}=3)$ 
Table 16. Caddo decorated sherds in the Cutler collection from San Pedro Creek, cont.

Engraved ( $\mathrm{n}=44)$, cont.

Patton-Poynor Engraved variety $(n=4)$

Horizontal-parallel engraved lines $(n=6)$

Cross-hatched engraved lines $(n=2)$

Cross-hatched engraved panel $(\mathrm{n}=2)$

Curvilinear engraved lines, bottles $(n=5)$

Diagonal engraved lines $(\mathrm{n}=2)$

Vertical and horizontal engraved panel $(n=1)$

Single straight line $(n=3)$

Brushed ( $\mathrm{n}=491)$

Parallel brushing marks $(\mathrm{n}=418)$

Overlapping brushing marks $(n=59)$

Horizontal brushed rims $(n=14)$

Incised ( $\mathrm{n}=11)$

Parallel incised lines $(\mathrm{n}=6)$

Opposed incised lines $(n=4)$

Single straight incised line $(n=1)$

Punctated ( $\mathrm{n}=54)$

Fingernail punctated $(\mathrm{n}=15)$

Tool punctated $(\mathrm{n}=36)$

Cane punctated $(\mathrm{n}=2)$

Weches Fingernail Impressed $(n=1)$

Pinched ( $\mathrm{n}=5)$

Brushed-appliqued ( $\mathrm{n}=1$ )

Brushed-tool punctated $(\mathrm{n}=6)$

Incised-punctated ( $\mathrm{n}=6$ )

Appliqued ( $\mathrm{n}=1)$

The remainder of the decorated sherds appear to be from the Allen phase Historic Caddo occupation of the San Pedro Creek area. This assemblage is dominated by Bullard Brushed jars decorated with brushing marks (79 percent) from the use of grass or frayed sticks to modify the exterior rim and body surfaces. Other decorations on utility ware vessels include incised lines (1.8 percent) drawn with a stick or bone (before a vessel was fired) on Maydelle Incised jars; punctations (either made with a finger, a tool such as a dowel, or a cut piece of cane, 8.7 percent); pinching ( 0.8 percent $)$ on Killough Pinched vessels; incised-punctated decorations ( 1 percent); brushed-punctated (1.0 percent); brushing and an appliqued fillet ( 0.2 percent); and appliqued ridges ( 0.2 percent). 
Fine ware carinated bowls, bowls, and bottles in this collection are decorated with engraved lines (7.1 percent). These engraved lines were cut into the surface of vessels after they had been fired or had been allowed to dry leather-hard, and then one or both vessel surfaces were well smoothed to polished with a pot polishing stone. The recognizable engraved types in the Cutler collection are Patton Engraved $(n=14)$, Hume Engraved $(n=2)$, and Poynor Engraved $(n=3)$, as well as a decorated variety that has elements of both Patton Engraved and Poynor Engraved $(n=4)$.

Engraved ceramic fine wares dominated by the types Patton Engraved, Hume Engraved, and Poynor Engraved are found on late $17^{\text {th }}$ to late $18^{\text {th }}$ century Hasinai Caddo sites in the Neches and Angelina River basins of East Texas, as are brushed utility ware jars. Given the general provenience of the Cutler collection to the San Pedro Creek valley and Mission Tejas State Park, it appears to be the case that the decorated ceramic vessel sherds in this collection are from Nabedache Caddo villages and settlements known to have been located along San Pedro Creek from ca. A.D. 1685 (if not earlier) to the 1830s.

\section{HO263, Ivie \#1}

The Ivie \#1 site was located in 2010 (Perttula et al. 2011) on a wooded sandy natural alluvial rise (240 feet amsl) along the edge of the San Pedro Creek floodplain (Figure 32). The current channel of the creek lies a short distance to the east of the site, and there is also a small tributary to the creek just to the south of the rise. The site has been damaged by recent well pad construction, but shovel testing on the rise documented intact midden deposits on the area of the rise, as well as intact archaeological deposits in one shovel test (ST 24) that are preserved underneath $(40-80 \mathrm{~cm} \mathrm{bs})$ the disturbed well pad fill.

Based on the distribution of Caddo artifacts on the surface, and in seven shovel tests (ST 18-24), the preserved remnants of the Ivie \#1 site cover approximately $3000 \mathrm{~m}^{2}(0.75$ acres $)$. The archaeological deposits extend to at least $80-100 \mathrm{~cm}$ bs. The density of artifacts in the shovel tests-principally lithic debris, charred nutshells, and Caddo pottery sherds - is considerable, at 27.1 artifacts per positive shovel test, or ca. 216.8 artifacts per $\mathrm{m}^{2}$ (Table 17). The highest densities of artifacts are in ST 22, ST 21, ST 19, and ST 23 at the southern end of the site (see Figure 32).

Table 17. Artifacts documented from shovel testing at the Ivie \#1 site (41HO263).

\begin{tabular}{llllllll}
\hline $\begin{array}{l}\text { Provenience } \\
(\mathrm{cm} \mathrm{bs})\end{array}$ & WC/NS & LD & FCR & T & PS* & DS & N \\
\hline Surface & - & 10 & - & - & 25 & 47 & 82 \\
ST 18, 0-100 & $2 / 2$ & 11 & - & $1^{* *}$ & 1 & - & 17 \\
ST 19, 0-100 & $4 / 3$ & 21 & 1 & - & 1 & 1 & 31 \\
ST 20, 0-80 & $-/ 3$ & 18 & - & - & - & 1 & 22 \\
ST 21, 0-80 & $1 / 4$ & 24 & - & - & - & 2 & 31 \\
ST 22, 0-80 & $3 / 2$ & 31 & - & - & 1 & - & 37 \\
ST 23, 0-80 & $1 / 1$ & 23 & 1 & - & 3 & 1 & 30 \\
ST 24, 40-80 & $-/ 6$ & 10 & 1 & - & 2 & 3 & 22 \\
\hline Totals & $11 / 21$ & 148 & 3 & 1 & 33 & 55 & 272 \\
\hline
\end{tabular}

$\mathrm{WC} / \mathrm{NS}=$ wood charcoal/nutshell; $\mathrm{LD}=$ lithic debris; FCR=fire-cracked rock; T=chipped stone tool; $\mathrm{PS}=$ plain sherd; DS=decorated sherd

*Does not include the 1 plain body sherdlet from ST 22, 40-60 cm bs

**Perdiz arrow point, $20-40 \mathrm{~cm}$ bs 


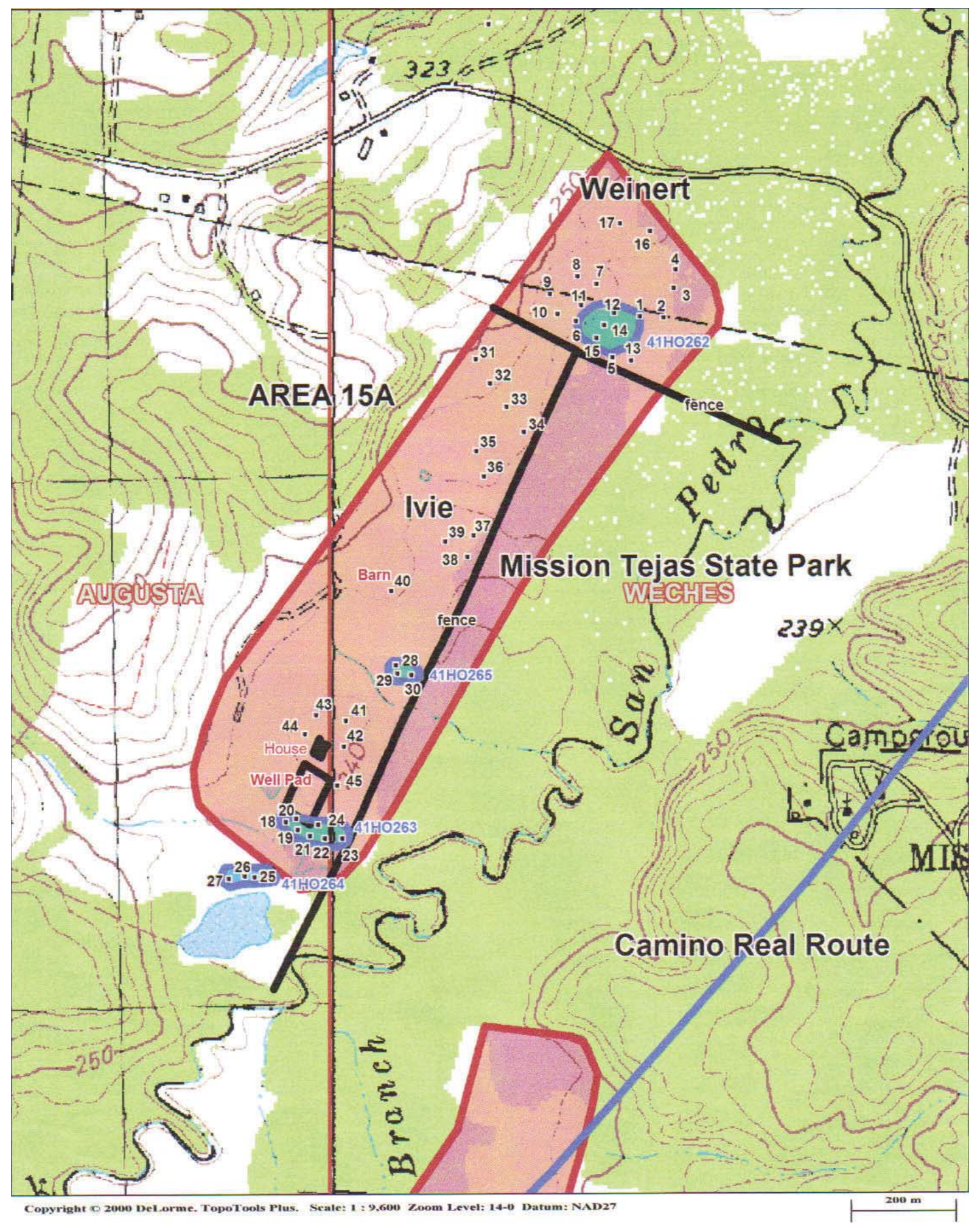

Figure 32. Sites and shovel test locations in the Area 15A Tract on San Pedro Creek, Houston County, Texas. 
The Caddo pottery from the Ivie \#1 site ( $\mathrm{n}=88$ sherds), including six rims, both plain (Figure 33a-b) and decorated, five base sherds, and 77 body sherds, is primarily tempered with grog (91.8 percent of the sherds have some grog in the paste), but 24.5 percent of the sherds analyzed in detail also have either burned bone or hematite temper inclusions in the paste; one sherd also has a notable amount of charred organics in the paste. The different proportions of temper used in vessel manufacture at the site are consistent with those from nearby Historic Caddo (Nabedache Caddo) sites at Mission Tejas State Park, with the exception that the use of crushed hematite temper is about 15 percent higher at the Ivie \#1 site than it is at the Nabedache Blanco and Nabedache Azul sites (Perttula and Nelson 2006:Figure 37 and Table 3).

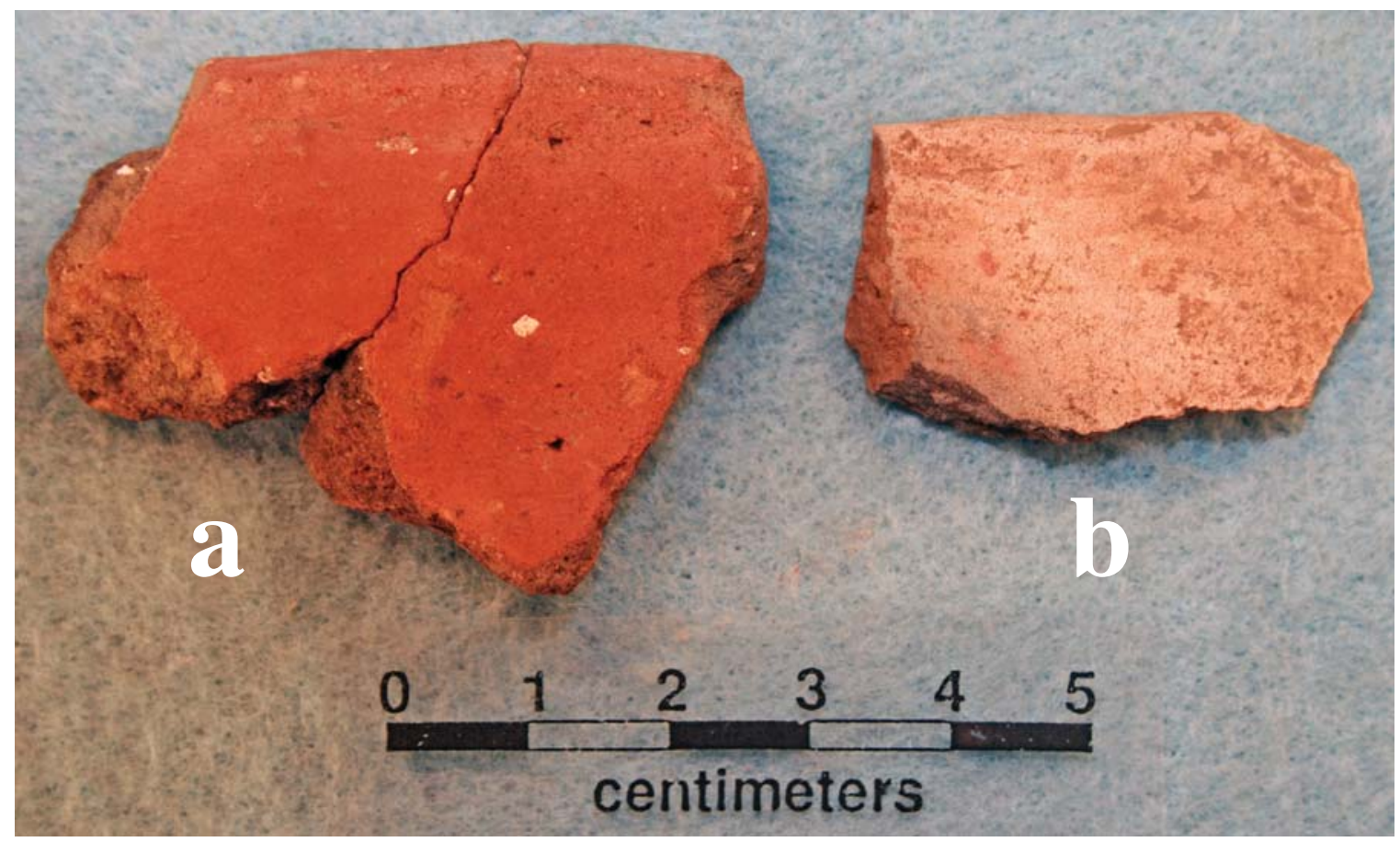

Figure 33. Plain rims from the Ivie \#1 site. Provenience: a, Surface; b, ST 22, 20-40 cm.

The sherds are from vessels that were fired predominantly in a low oxygen or reducing environment (79.5 percent), with many of the vessels allowed to cool in the open air, leaving thin oxidized bands along either one or both vessel surfaces (cf. Teltser 1993). Another 14.3 percent are from vessels fired in a high oxygen or oxidizing environment, and 6.1 percent of the sherds analyzed in detail from the Ivie \#1 site are from vessels that were incompletely oxidized during firing. At the Nabedache Blanco and Nabedache Azul sites, the sherds are from vessels fired in the same way as those from the Ivie \#1 site, namely in a reducing environment (68.4-77.1 percent), with much lower proportions of sherds fired in either an oxidizing (7.7-13.0 percent) or incompletely oxidizing (12.0-13.4 percent) environment.

Both the temper and firing conditions data from the Ivie \#1 sherds strongly suggest that the ceramics made and used there derive from the same Nabedache Caddo ceramic tradition more fully documented in late $17^{\text {th }}$-mid- $18^{\text {th }}$ century sites at nearby Mission Tejas State Park. The decorations on the sherds from the Ivie \#1 site, as well as comparable plain to decorated sherd ratios (P/DR), attest to the use of virtually the same decorative practices on pottery vessels as had been noted at the nearby historic Nabedache Caddo sites (Perttula and Nelson 2006, 2007a), particularly the heavy use of brushed vessels among the utility wares (Table 18), and similar proportions for most of the other kinds of utility wares (i.e., incised, punctated, and neck banded). 
Table 18. Decorative methods represented in the ceramic sherds at San Pedro Creek sites.

\begin{tabular}{|c|c|c|c|c|}
\hline \multirow{2}{*}{ Attributes } & \multirow{2}{*}{$\begin{array}{l}\text { Ivie \#1 } \\
41 \mathrm{HO} 263\end{array}$} & \multicolumn{3}{|c|}{ Historic Nabedache Caddo Sites } \\
\hline & & $41 \mathrm{HO} 211$ & $41 \mathrm{HO} 214$ & 41HO91 \\
\hline $\mathrm{P} / \mathrm{DR}$ & 0.60 & 0.34 & 0.32 & 0.56 \\
\hline$\%$ Brushed among & & & & \\
\hline all sherds & 36.4 & 53.2 & 56.7 & 44.2 \\
\hline$\%$ Brushed among & & & & \\
\hline $\begin{array}{l}\text { decorated sherds } \\
\% \text { Engraved among }\end{array}$ & 58.2 & 71.4 & 76.0 & 69.2 \\
\hline all sherds & 4.5 & 10.6 & 7.8 & 9.8 \\
\hline$\%$ Incised among & & & & \\
\hline all sherds & 8.0 & 9.6 & 5.3 & 4.9 \\
\hline$\%$ Punctated among & & & & \\
\hline all sherds & 11.4 & - & 2.6 & 3.3 \\
\hline $\begin{array}{l}\% \text { Neck banded } \\
\text { among all sherds }\end{array}$ & 1.1 & 2.2 & - & 2.3 \\
\hline $\begin{array}{l}\% \text { Appliqued } \\
\text { among all sherds }\end{array}$ & - & 1.8 & - & - \\
\hline
\end{tabular}

Sample sizes: Ivie \#1 (33 plain sherds and 55 decorated sherds); $41 \mathrm{HO} 211$ (24 plain sherds and 70 decorated sherds); 41HO214 (55 plain sherds and 172 decorated sherds); 41HO91 (22 plain sherds and 39 decorated sherds), see Perttula and Nelson (2006, 2007a, 2007b).

The only substantial difference between these San Pedro Creek Caddo sites is the absence of Patton Engraved fine ware sherds at the Ivie \#1 site (among the four engraved sherds found there), and its ubiquity at the Historic Nabedache Caddo sites. If the absence of Patton Engraved at the Ivie \#1 site is not simply a product of decorated sherd sample size, but an accurate reflection that it was not made and used there - and we take the other measurements of very similar decorative methods into account (see Table 18), this would suggest that the Caddo occupation at the Ivie \#1 site dates just prior to ca. A.D. 1650, perhaps from ca. A.D. 1600-1650. Thus, the site may well have been occupied just prior to sustained European contact and the historic use of El Camino Real de los Tejas by the Caddo and European groups.

The fine ware sherds at the Ivie \#1 site include two rim sherds and two body sherds. The first rim has a series of closely-spaced horizontal to diagonal engraved lines that probably encircle the vessel, while the second rim has both horizontal and cross-hatched engraved lines on it (Figure 34e). Neither rim sherd, both from the surface, can be identified as a known East Texas Late Caddo or Historic Caddo ceramic type (see Suhm and Jelks 1962).

The first engraved body sherd has a single curvilinear engraved line. The second body sherd is from a bottle with a large central element that consists of a circle with crossed lines, with curvilinear engraved lines apparently encircling this central element (Figure 35). This bottle sherd may be from a Poynor Engraved vessel (see Kleinschmidt 1982:Figures 19 and 20). The Poynor Engraved type is principally found in Late Caddo (ca. A.D. 1400-1650) contexts in the Neches River basin, but has been found occasionally in Historic Caddo burial features in the region (Kleinschmidt 1982:Table 19; Perttula 2011).

Utility wares $(n=51)$ from the Ivie \#1 site are dominated by brushed body sherds $(n=27)$ from Bullard Brushed cooking and storage jars. These include 20 body sherds with parallel (or vertically oriented) brushing (see Figure 34c-d), five with opposed brushing marks, one with overlapping brushing, and one with vertical brushing. 


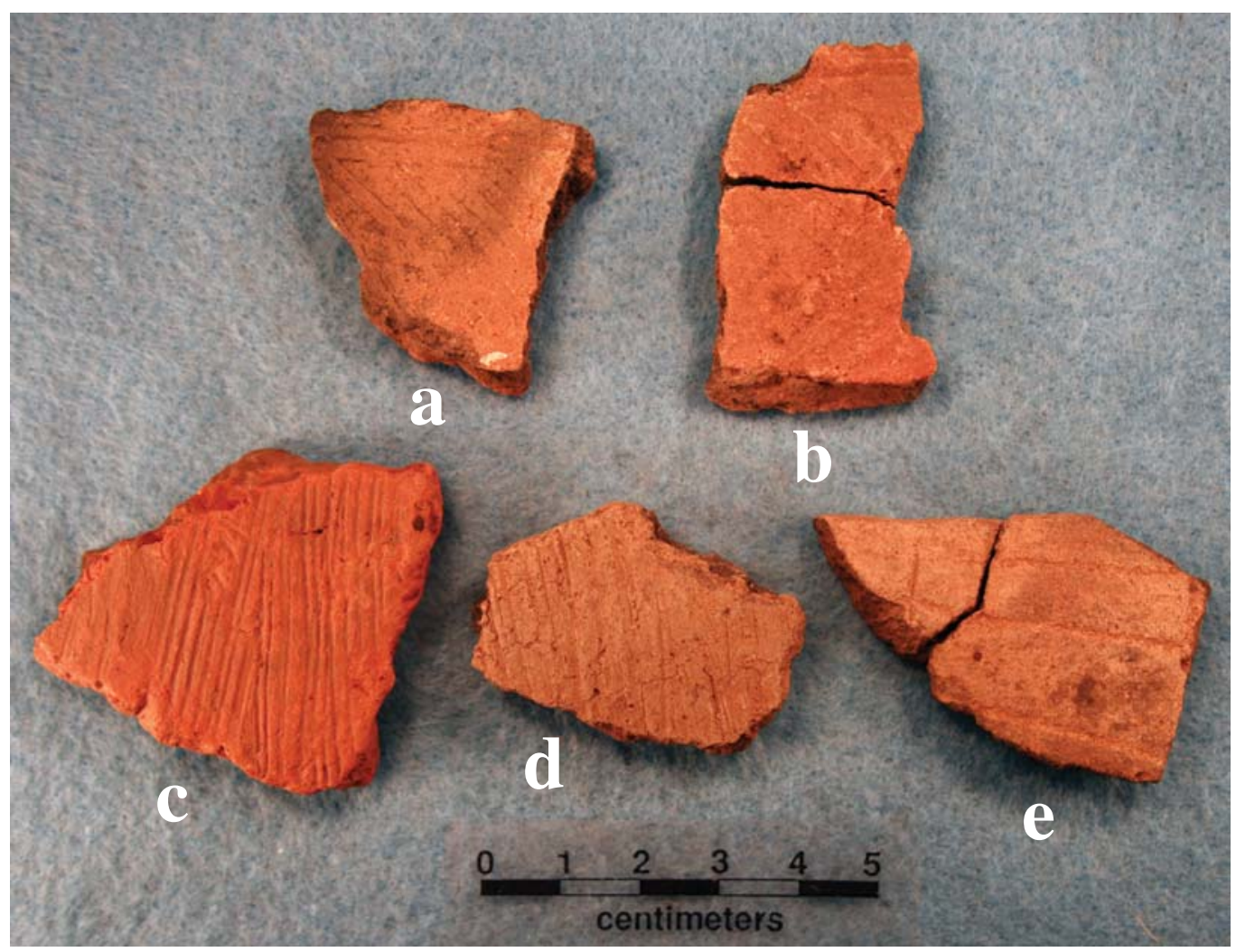

Figure 34. Decorated sherds from the Ivie \#1 site: a-b, incised body sherds; c, parallel brushed; d, parallel brushed; e, horizontal to diagonal engraved rim sherd. Provenience: a, Surface; b, Surface; c, Surface; d, Surface; e, Surface.

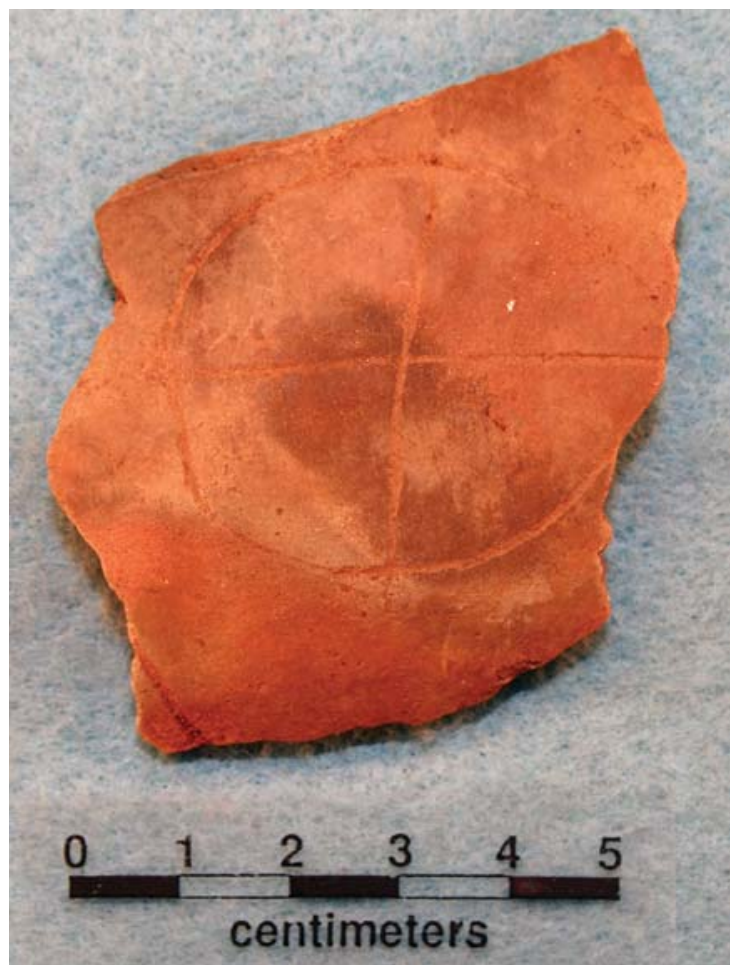

Figure 35. Engraved bottle sherd from the Ivie \#1 site. Provenience: ST 19, 20-40 cm bs.
Five other sherds have brushed and punctated decorations. This includes rim and body sherds $(n=4)$ with parallel brushing marks that have either rows of circular (Figure 36c) or tool punctates pushed through the brushing, and a body sherd with parallel brushing adjacent to a row of tool punctates.

There are eight sherds from an undefined type or types decorated with punctations. Several $(n=4)$ have rows of tool punctations or rows of fingernail punctations $(n=1)$, one has alternate rows of crescent-shaped punctations (see Figure 36d), a rim has rows of circular punctations (see Figure 36b), and one has only a single punctation on a body sherd.

One of the seven incised body sherds collected from the surface or in the shovel testing of the Ivie \#1 site may be from a Maydelle Incised jar. It has a series of broad opposed diagonal incised lines (see Figure 34b). Other decorative elements represented in the incised sherds that may also be from Maydelle Incised vessels include parallel incised lines $(\mathrm{n}=2)$, opposed incised lines ( $\mathrm{n}=2$, see Figure $34 \mathrm{a}$ ), and body sherds with a single straight incised line $(\mathrm{n}=2)$. 


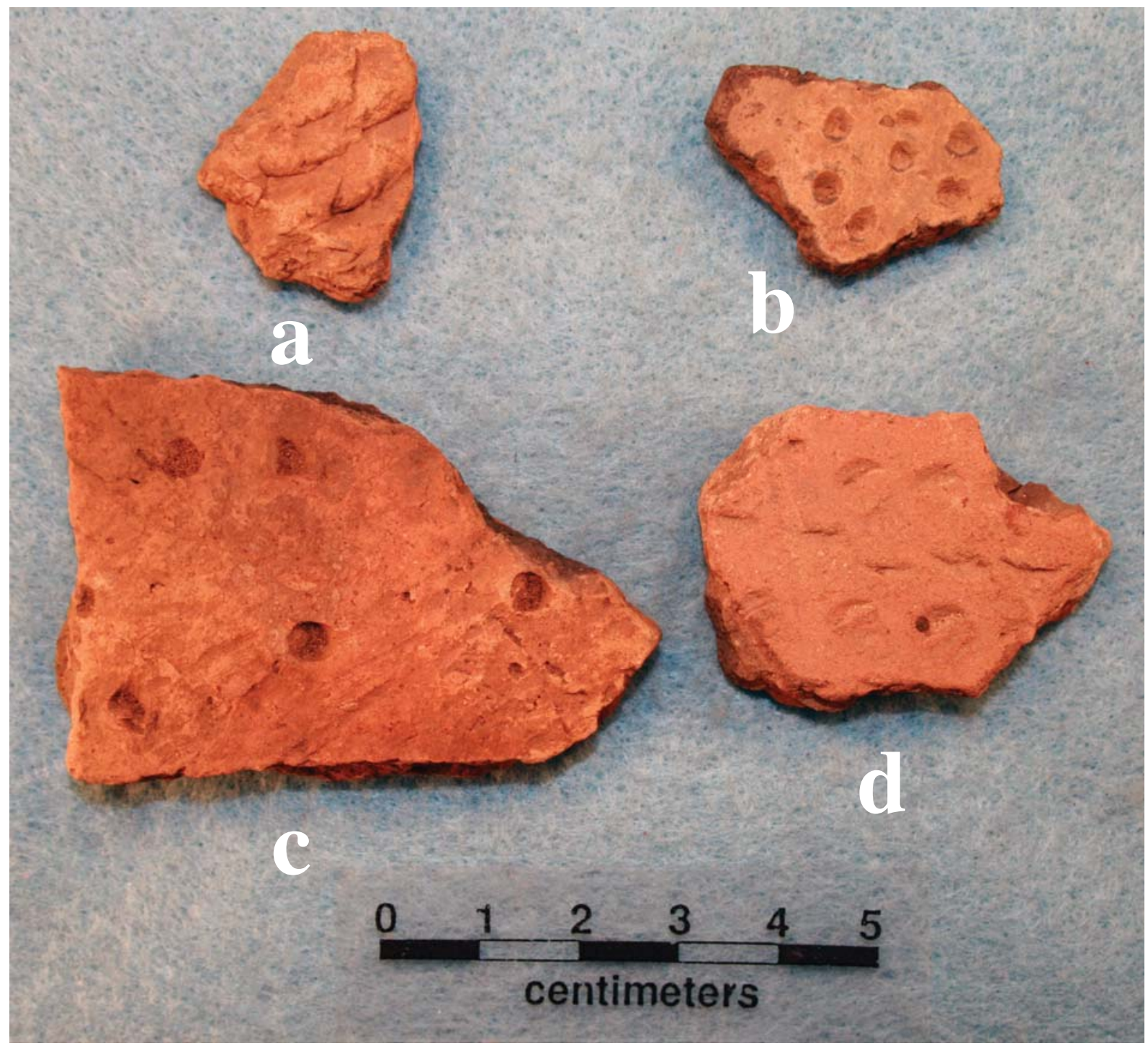

Figure 36. Utility wares from the Ivie \#1 site: a, neck banded body sherd; b, circular punctated rim sherd; c, brushed-punctated body sherd; d, crescent-shaped punctated body sherd. Provenience: a, Surface; b, Surface; c, ST 21, 20-40 cm; d, Surface.

There are two body sherds with incised-punctated decorations in the Ivie \#1 sherd assemblage. The first of these has opposed incised lines that are intersected by a row of tool punctations, while the second body sherd has a single straight incised line adjacent to a zone of tool punctations. The two neck banded sherds (see Figure 36a) are from La Rue Neck Banded jars that have horizontal crimped or neck banded rows on the vessel rim.

The lithic debris from the Ivie \#1 site attests to the manufacture of chipped stone tools during the Caddo occupation of the site, as there is no evidence of an earlier pre-ceramic Archaic or Woodland period ceramic-bearing occupation. In addition to lithic debris, there are three small pieces of fire-cracked rock from three of the shovel tests (see Table 17).

Consistent with both a Late Caddo as well as an Historic Caddo occupation in the Neches-Angelina river basin, a single Perdiz arrow point was documented from ST $18(20-40 \mathrm{~cm}$ bs) at the Ivie \#1 site. 
This point is made from a local petrified wood, has been unifacially flaked to shape, and has slightly downward-pointing barbs (Figure 37). It is $19.6 \mathrm{~mm}$ in length, $13.8 \mathrm{~mm}$ in width, $2.5 \mathrm{~mm}$ thickness, and has a $5.4 \mathrm{~mm}$ stem width.

Raw materials represented in the lithic debris assemblage include the following local materials: petrified wood $(n=26)$, quartzite $(n=28)$, Glover quartzite $(n=76$, see Perttula and Nelson [2006] for a discussion concerning this distinctive Neches River basin raw material), ferruginous sandstone $(n=1)$, and red chert $(n=3)$. These raw materials comprise 90.5 percent of the lithic debris from the Ivie \#1 site. Probable non-local lithic raw materials (most likely from Central Texas source areas or expansive gravel deposits east of the Edwards Plateau) in the lithic debris are: light gray chert $(n=4)$, translucent gray chert $(n=1)$, gray chert $(n=4)$, grayish-brown chert $(n=2)$, white chert $(n=1)$, and yellowish-gray chert $(n=2)$. These much rarer tool stones account for 9.5 percent of the lithic debris sample.

Charred hickory nutshells $(\mathrm{n}=21)$ and wood charcoal $(\mathrm{n}=11)$ are relatively common in the archaeological deposits at the Ivie \#1 site, due to the enhanced preservation conditions found in the midden deposits. Their presence also suggests that there may be pit features or other areas of concentrated charred organic remains at the site.

\section{Faunal Remains, by LeeAnna Schniebs}

Shovel testing at the Ivie \#1 site yielded 22 faunal specimens (Table 19). They were recovered from five levels in six shovel tests. The sample is comprised of indeterminate vertebrate, deer, and large mammal remains, with a combined weight of 9.7 grams. Eleven pieces are burned.

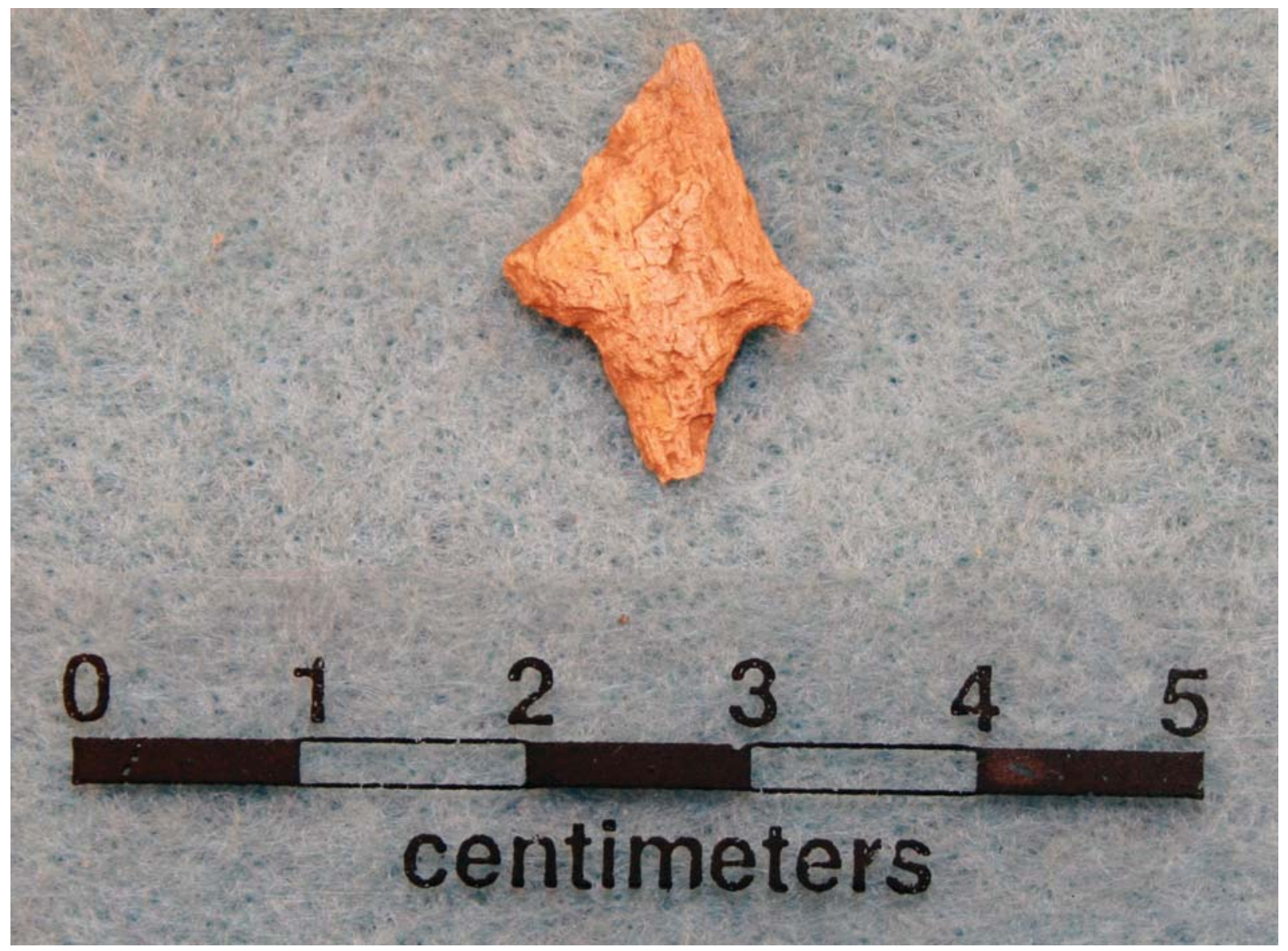

Figure 37. Perdiz arrow point from the Ivie \#1 site (41HO263). 
Table 19. Summary of Faunal Recovery at the Ivie \#1 site (41HO263).

\begin{tabular}{|c|c|c|c|c|}
\hline Site & Provenience (cm bs) & Taxon & Element & NISP \\
\hline \multirow[t]{14}{*}{$41 \mathrm{HO} 263$} & ST $18,80-100$ & unidentifiable & UID & 1 \\
\hline & ST 19, 20-40 & deer & antler & 3 \\
\hline & ST $19,40-60$ & large mammal & UID & 1 \\
\hline & ST $20,0-20$ & large mammal & UID & 1 \\
\hline & ST $20,20-40$ & deer & maleolus & 1 \\
\hline & ST $20,20-40$ & deer & metapodial & 1 \\
\hline & ST $20,20-40$ & large mammal & UID & 3 \\
\hline & ST $20,60-80$ & deer & metapodial & 1 \\
\hline & ST $20,60-80$ & deer & petrous & 1 \\
\hline & ST $21,60-80$ & deer & petrous & 1 \\
\hline & ST $23,40-60$ & large mammal & UID & 1 \\
\hline & ST $24,40-60$ & deer & tooth & \\
\hline & fragment & 6 & & \\
\hline & ST $24,60-80$ & unidentifiable & UID & 1 \\
\hline
\end{tabular}

UID=unidentifiable; NISP=number of identifiable specimens

The bones are highly fragmented, preventing specific identification in most cases; deer (Odocoileus virginianus) is the only identifiable animal. Few interpretations can be made except that the Caddo supplemented their diet by hunting, and that deer was the primary meat source; they were hunted in the wooded edges of East Texas. The presence of cranial elements (antler, tooth fragments, petrous) and leg bones (metapodial and maleolus) suggests that the bones came from a kill site. Often the animal was killed and butchered/processed at one location, and the meatier parts of the animal were taken back to another area for preparation, cooking, and consumption. Further investigations at the site would provide more information as to the subsistence practices of the Late Caddo populations that lived in the upper Neches River basin, and also provide a point of contrast with the use and hunting of game animals on Historic Caddo sites.

\section{HO264, Ivie \#2}

The Ivie \#2 site is situated on a sandy rise (230 feet amsl) at the edge of the San Pedro Creek floodplain (see Figure 32). The rise is in a maintained pasture, cultivated for winter grasses, with good (40 percent) surface visibility. A small tributary to San Pedro Creek is about $50 \mathrm{~m}$ to the north.

In addition to numerous prehistoric Caddo artifacts that were visible on the surface of the site, three shovel tests were excavated on the rise to determine if there were intact archaeological deposits preserved on the landform. Each of the shovel tests had prehistoric artifacts to $60 \mathrm{~cm}$ bs (Table 20); the archaeological deposits may be deeper, but the water table was encountered at $60 \mathrm{~cm}$ bs during the shovel testing. The density of prehistoric artifacts is moderate: 12.0 artifacts per positive shovel test (ca. 96 artifacts per $\mathrm{m}^{2}$ ). The site covers an estimated $4000 \mathrm{~m}^{2}$ (ca. 1 acre).

Table 20. Artifacts documented from shovel testing at the Ivie \#2 site (41HO264).

\begin{tabular}{lllllll}
\hline $\begin{array}{l}\text { Provenience } \\
(\mathrm{cm} \text { bs })\end{array}$ & $\begin{array}{l}\text { Wood } \\
\text { Charcoal }\end{array}$ & $\begin{array}{l}\text { Lithic } \\
\text { Debris }\end{array}$ & Tools & $\begin{array}{l}\text { Plain } \\
\text { Sherds }\end{array}$ & $\begin{array}{l}\text { Decorated } \\
\text { Sherds }\end{array}$ & $\mathrm{N}$ \\
\hline Surface & - & 24 & - & 3 & 4 & 31 \\
ST 25, 0-60 & - & 13 & - & - & - & 13 \\
ST 26, 0-60 & 2 & 10 & $1^{*}$ & - & - & 13 \\
ST 27, 0-60 & 1 & 9 & - & - & - & 10 \\
\hline Totals & 3 & 56 & 1 & 3 & 4 & 67 \\
\hline
\end{tabular}

*dart point, $20-40 \mathrm{~cm}$ bs 
None of the shovel tests encountered any Caddo pottery sherds, but a contracting stem Gary dart point stem fragment-diagnostic of a Woodland period occupation dating from ca. 2500-1200 years B.P.- was noted in ST 26 (20-40 cm bs) (see Table 19). The Gary point was made from a heat-treated local quartzite. Measurements of the stem width $(12.0 \mathrm{~mm})$ and thickness $(5.4 \mathrm{~mm})$ suggest that the Ivie \#2 point is an example of a Gary, var. Camden point, the latest of the Woodland period Gary points, estimated by Schambach $(1982,1998)$ to date from ca. $1700-1200$ B.P.

The seven ceramic sherds (six body sherds and one base sherd) found at the Ivie \#2 site are tempered primarily with grog (crushed sherds or fired clay), with the regular use of both crushed bone and hematite aplastics. The sherds are from vessels fired primarily in a low oxygen or reducing environment (71 percent), but two body sherds were from a vessel (or vessels) that was incompletely oxidized during firing (cf. Teltser 1993). The sherds are apparently from relatively large vessels, based on body sherd wall thickness values that range from $5.8-10.0 \mathrm{~mm}$; the one flat base sherd is $10.2 \mathrm{~mm}$ thick.

Four of the body sherds from the Ivie \#2 site are decorated: two with rows of tool punctations (Figure 38a); one with closely-spaced parallel incised lines; and a fourth sherd with parallel brushing marks (Figure 38b). None of the sherds are sufficiently large in size, or on those parts of vessels, that would allow them to be typologically identified. Nevertheless, the presence of brushed sherds in the small ceramic assemblage is indicative of a Caddo occupation that could have started in Middle Caddo period times (ca. A.D. 1200-1400), but it is more likely that the Caddo occupation took place sometime after ca. A.D. 1400. Brushed utility ware pottery is prevalent only after ca. A.D. 1400 in this part of the Neches River basin (see Perttula and Nelson 2006, 2007a), and is particularly abundant in Historic Caddo Allen phase components. In Historic Caddo components investigated at Mission Tejas State Park, directly east of the Area 15A survey tract (see Figure 32), brushed pottery comprises between 53-57 percent of all the sherds at the Nabedache Blanco (41HO211) and Nabedache Azul (41HO214) sites.

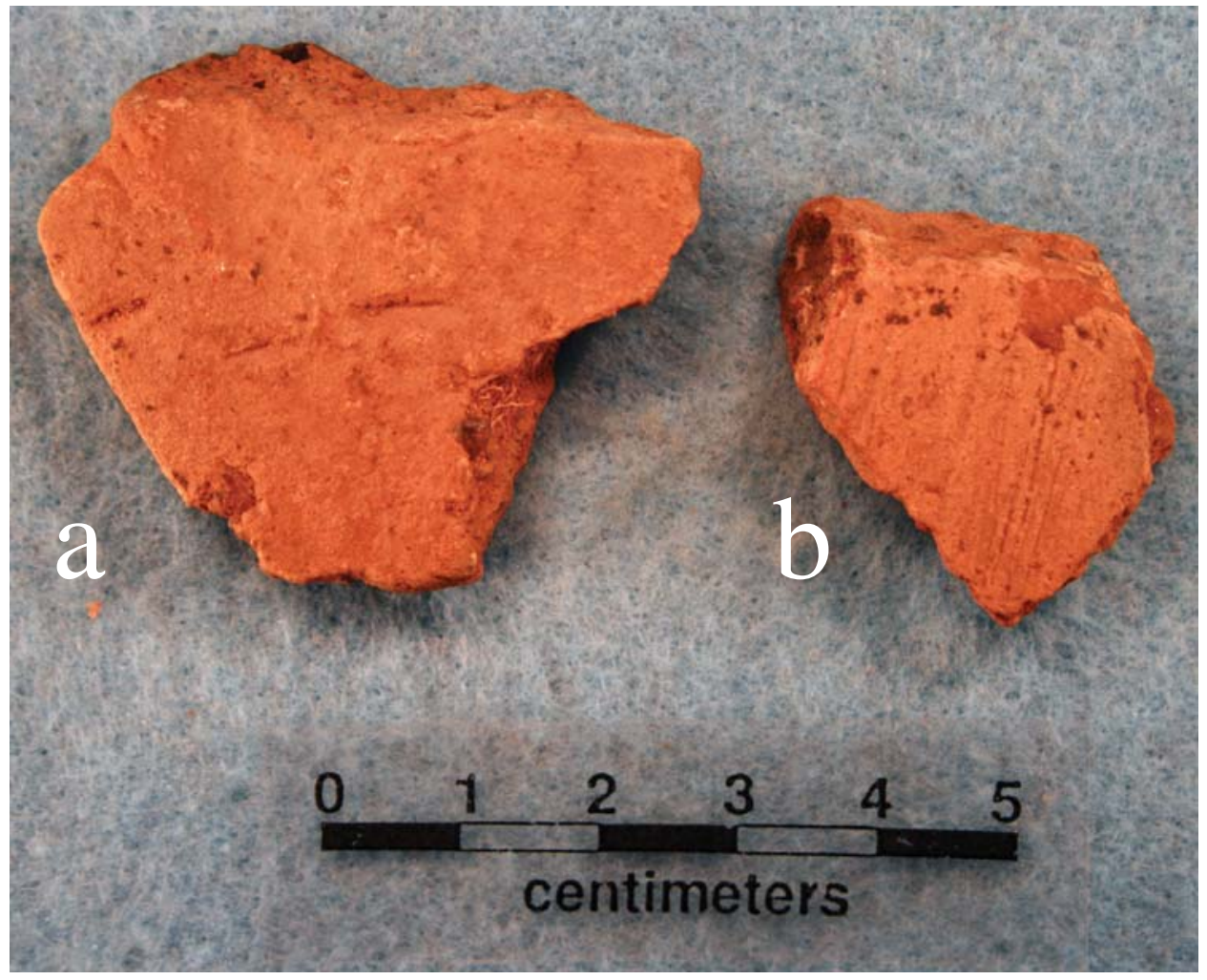

Figure 38. Utility ware sherds from the Ivie \#2 site (41HO264): a, tool punctated body sherd; b, parallel brushed body sherd. Provenience: a-b, Surface. 
Lithic debris was common on the surface of the Ivie \#2 site as well as in each of the three positive shovel tests. Materials represented in the lithic debris includes both local-quartzite $(n=8$, sometimes heat-treated), Glover quartzite $(n=27)$, hematite $(n=1)$, red chert $(n=1)$, quartz $(n=1)$, and petrified wood $(n=7)$ - and non-local (i.e., Central Texas) sources. Among the latter are brownish-gray chert $(n=1)$, grayish-brown chert $(n=1)$, dark gray chert $(n=3)$, translucent gray chert $(n=2)$, gray chert $(n=2)$, and light gray chert $(n=2)$. Local raw materials comprise 80 percent of the lithic debris from the Ivie \#2 site; these raw materials were gathered from both local stream gravel and bedrock sources, based on cortical pieces having either stream-rolled or bedrock-roughened surfaces.

Wood charcoal was also noted between $20-60 \mathrm{~cm}$ bs in ST 26 and ST 27 at the Ivie \#2 site (see Perttula et al. 2011:Table A2.2).

\section{Synthesis of Caddo Settlement and Use of the San Pedro Creek Valley}

There are 17 ancestral Caddo sites and/or components known in the San Pedro Creek valley (as of October 2015) in the Neches River basin in East Texas. These sites were primarily found either during a 1944 archaeological reconnaissance of part of the valley by Alex D. Krieger of The University of Texas, or during several archaeological survey and test excavation projects conducted at Mission Tejas State Park, and they are concentrated in the eastern part of the valley near the confluence of San Pedro Creek and the Neches River.

The first documented aboriginal use of the valley was during the Middle Archaic period, as several ca. 6000 years B.P. Calf Creek dart points are known to have been found at the George Moore \#1b site (41HO64). Five sites have evidence of Woodland period settlement dating between ca. 500 B.C. and A.D. 800 , including Gary dart points and/or Goose Creek Plain, var. unspecified sandy paste ceramic sherds. One of the sites, Butler Branch (41HO216), has a buried Woodland period component with a calibrated 2 sigma age range on charred nutshells of A.D. 400-660.

There is a single Middle Caddo period settlement also known at the Butler Branch site in the San Pedro Creek valley. The occupation there dates between cal. A.D. 1200-1290. Five of the San Pedro Creek Caddo sites date to the Late Caddo period (ca. A.D. 1400-1680) and the Frankston phase, indicative of the first intensive and wide-ranging settlement and use of the valley by Caddo peoples; these peoples appear to be ancestral Nabedache Caddo. However, the peak in the Caddo settlement and use of the San Pedro Creek valley took place after ca. A.D. 1680 by Nabedache Caddo groups: 10 of the known sites in the valley have occupations by historic Nabedache peoples; they are part of the Nabedache cluster of historic Allen phase sites in East Texas (Figure 39). To date, no archaeological evidence of the 1690-1693 Spanish mission of San Francisco de los Tejas has been found in the San Pedro Creek valley. As far as can be determined by the material culture evidence, these Nabedache Caddo sites were occupied between ca. A.D. 1680 and A.D. 1760, and they are marked by both traditional Caddo ceramic vessel sherds and a diverse assortment of European trade goods, including glass beads and metal goods. It is likely that there are later $18^{\text {th }}$ century Nabedache Caddo archaeological sites in the San Pedro Creek valley, but they have yet to be found.

Based on historic and archival documents, there were also $19^{\text {th }}$ century Caddo settlements in the San Pedro Creek valley, although none have been recorded by archaeologists. One such area of known early 19th century Caddo settlements is on Grass House Prairie on the upper reaches of San Pedro Creek where it is crossed by several routes of the El Camino Real de los Tejas. The "Grass House Prairie" was apparently named by land surveyors and perhaps as well as members of the Republic of Texas militia during various campaigns against East Texas Caddo groups (see Smith 1995:138-141), who attempted to burn out a Caddo village of grass- and thatch-covered Caddo houses there (Bob D. Skiles, May 2009 personal communication). An early account by John Holland Jenkins stated that: 


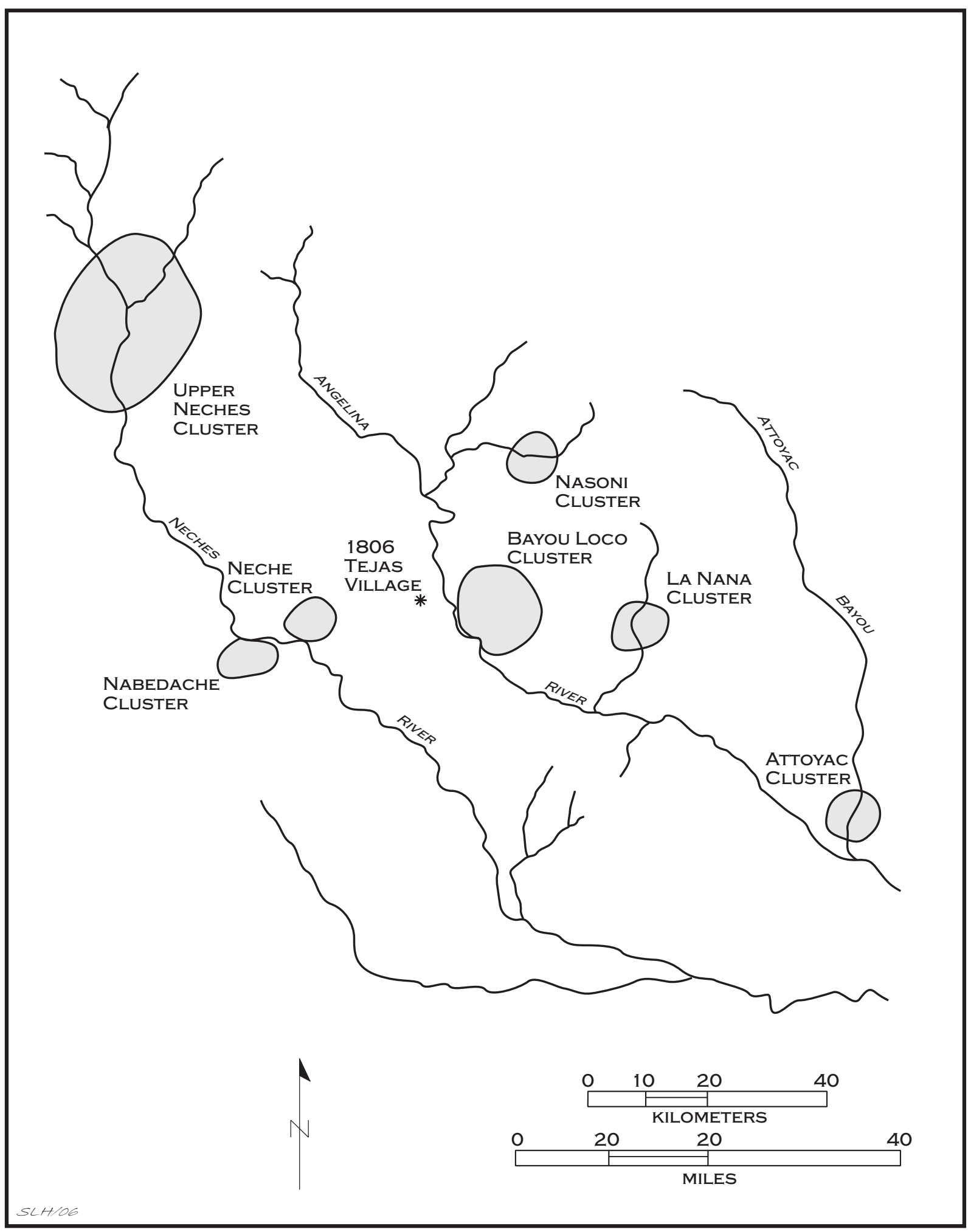

Figure 39. Allen phase site clusters in the Neches and Angelina River basins in East Texas. 
...in 1839 or 1840, [Gen. Edward] Burleson was returning from an unsuccessful Indian campaign when one of his men proposed leading the way to a village of Tejas Indians, a hostile tribe that covered their tents or wigwams with grass. Burleson with the main army paid no special attention to the information and came on home, but twelve or thirteen men volunteered to accompany the self-appointed guide, anxious for the excitement and adventure as well as the plunder they might secure...They struck off to burn the village with its roofs of dry grass. On their way, however, while they were cutting a bee tree, they were surprised and attacked by a large band of Indians.

Taking refuge in a hollow, they fought faithfully and kept the Indians off. But...the savages finally set fire to the grass surrounding them and they were compelled to retreat. Nearly all of them were killed, but the dense smoke concealed a few, who escaped... (Jenkins 1987:181).

Grass House Prairie, also known as Murchison's Prairie after the name of an 1840s Anglo-American settler, is a natural prairie on the north side of San Pedro Creek (see Figure 40). According to Kennedy (1892:21):

Murchison's prairie...comprises an area of about two miles square, extending over a greater portion of the Jose Maria Procella league, and a portion of the northeastern corner of the Stephen Rodgers headright. Unlike the prairie regions of the southern portion of the county, Murchison's prairie does not owe its existence to lacustrine formation. This prairie, which lies somewhat lower than the surrounding country, appears to owe its prairie origin and general absence of trees to the impervious nature of the subsoils...trees are springing up and encroaching upon the treeless area. Like the prairies in the southern portion of the county, Murchison's prairie will, in a few years, be as well wooded as the surrounding country.

\section{Summary and Conclusions}

Archaeological work over the years, beginning with Alex Krieger's reconnaissance in 1944, has identified a number of Caddo sites of post-A.D. 1680s age along San Pedro Creek in Houston County, Texas. There are also ancestral Caddo sites along the creek that date prior to European contact, indicating that the lower course of the creek was home to Caddo peoples by ca. A.D. 1400, if not earlier; several of the sites also have either Archaic or Woodland period artifacts, hinting at the first uses of the San Pedro Creek valley. Archival sources and historic maps of the San Pedro Creek area and East Texas (Figure 41) indicate that these Caddo sites on an eastward-flowing tributary to the Neches River are the material remains of Nabedache Caddo habitation sites and cemeteries. In addition to a variety of ceramic vessel sherds and chipped stone artifacts, these sites also contain a wide range of European trade goods that were obtained from Spanish and French traders, colonists, and missionaries.

It is known that the Spanish constructed the first mission in 1690 among the Nabedache Caddo peoples living on San Pedro Creek, Mission San Francisco de los Tejas, but the archaeological remains of the mission compound have yet to be found. Historical and archival information indicates that the mission was about 10 miles upstream on San Pedro Creek from its confluence with the Neches River, in an area that has received almost no archaeological survey investigations in the last $40+$ years. This would place the mission well upstream from the Nabedache Caddo sites identified and discussed in this article. These sites are nevertheless part of the community the Spanish referred to as San Pedro de los Nabedaches. 


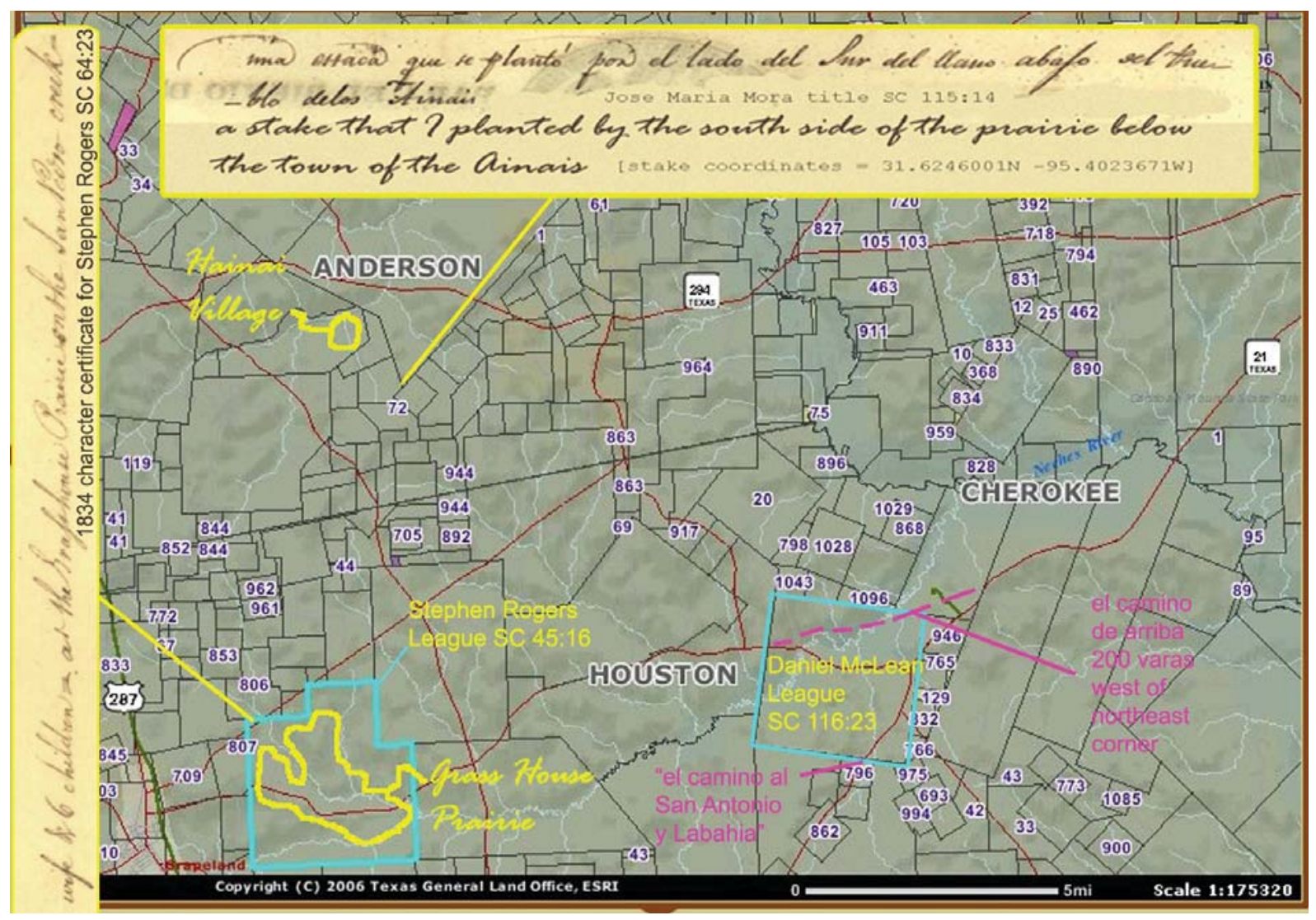

Figure 40. Known extent of the Grass House Prairie on San Pedro Creek and along El Camino Real de los Tejas. Map provided courtesy Bob D. Skiles.

I hope that a concerted archaeological and historical/archival research effort can be mounted in the years to come that focuses on defining the ancestral Caddo community of San Pedro de los Nabedaches. The purposes of that effort would be to not only locate the 1690-1693 Mission San Francisco de los Tejas on San Pedro Creek, but would be to also obtain more detailed information on the archaeological character of the associated pre- and post-A.D. 1690 Nabedache sites and community preserved along the creek.

\section{Acknowledgments}

Bo Nelson and Mark Walters were integral parts of the various archaeological investigations we conducted along San Pedro Creek, and this article could not have been done without their active participation. I thank the now deceased Robert S. Weddle for his discussions concerning San Pedro de los Nabedaches and the location of the 1690 Spanish mission on San Pedro Creek, as well as for a copy of his 2012 report on Camino Real de los Tejas. Bob D. Skiles provided information and maps regarding the $19^{\text {th }}$ century Grass House Prairie on San Pedro Creek. Lance Trask and Sandra Hannum prepared the figures in this article, and Bo Nelson took the artifact photographs. Finally, Marybeth Tomka and Jonathan Jarvis at the Texas Archeological Research Laboratory at The University of Texas at Austin facilitated access to the records and collections from some of the San Pedro Creek sites. 


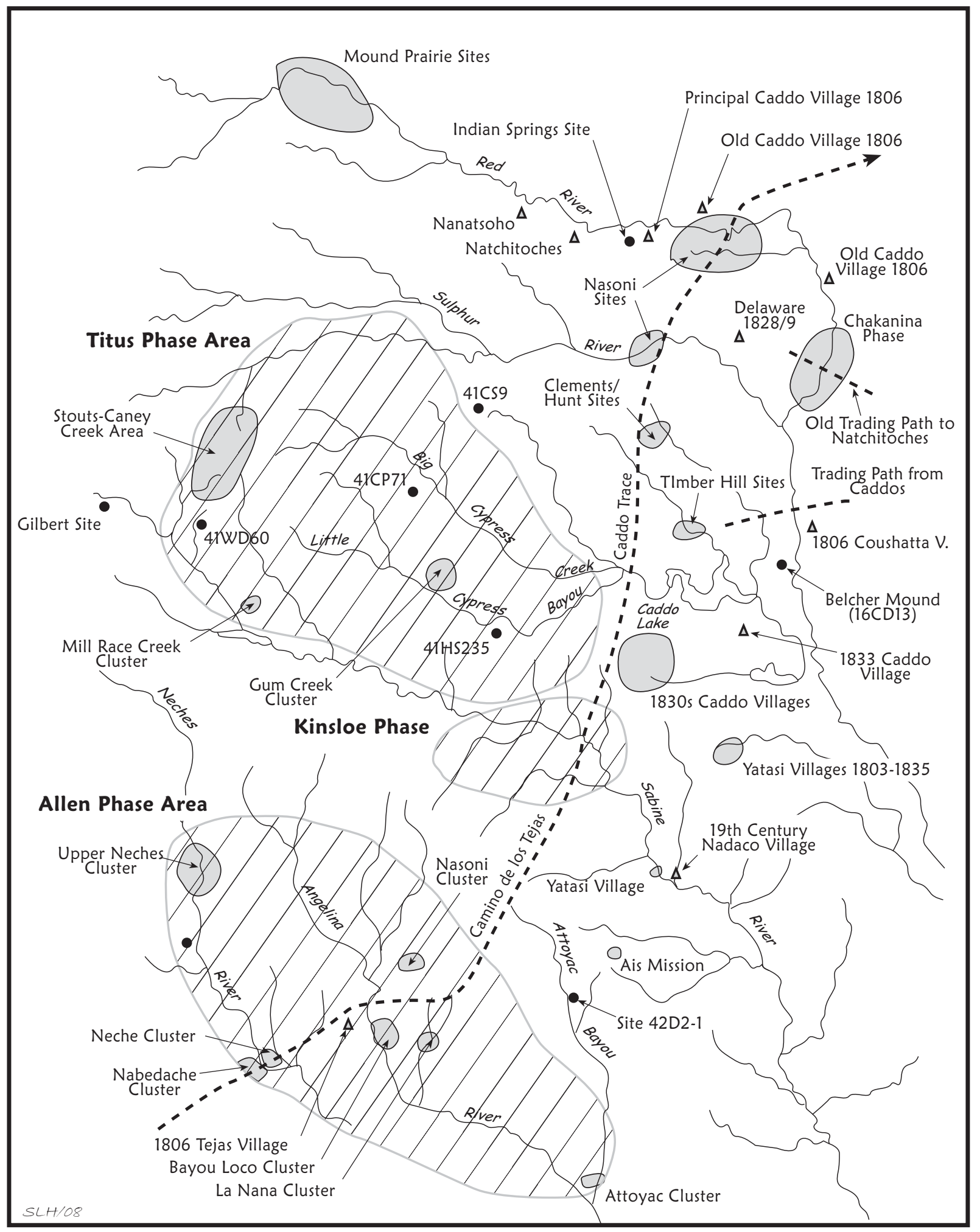

Figure 41. The Nabedache Caddo in East Texas: Historic Caddo sites and associated phases in East Texas, and the reported locations of Caddo villages and communities. 


\section{References Cited}

Adams, W. H.

2002 Machine Cut Nails and Wire Nails: American Production and Use for Dating $19^{\text {th }}$ Century to Early $20^{\text {th }}$ Century Sites. Historical Archaeology 36(4):66-88.

Aten, L, E. and C. N. Bollich

2002 Late Holocene Settlement in the Taylor Bayou Drainage Basin: Test Excavations at the Gaulding Site (41JF27), Jefferson County, Texas. Studies in Archeology 40, Texas Archeological Research Laboratory, The University of Texas at Austin, and Special Publication No. 4, Texas Archeological Society, San Antonio.

Berlandier, J. L.

1969 The Indians of Texas in 1830. Edited by J. C. Ewers. Smithsonian Institution Press, Washington, D.C.

Bolton, H. E.

1908 The Native Tribes About the East Texas Missions. Quarterly of the Texas State Historical Association 9:249-276.

1987 The Hasinai: Southern Caddoans as seen by the earliest Europeans. University of Oklahoma Press, Norman.

Brain, J. P.

1979 Tunica Treasure. Papers of the Peabody Museum of Archaeology and Ethnology, Volume 71. Peabody Museum of Archaeology and Ethnology, Harvard University, Cambridge.

1988 Tunica Archaeology. Papers of the Peabody Museum of Archaeology and Ethnology, Volume 78. Peabody Museum of Archaeology and Ethnology, Harvard University, Cambridge, Massachusetts.

Bruseth, J. E. and N. A. Kenmotsu

1993 From Naguatex to the River Daycao: The Route of the Hernando de Soto Expedition Through Texas. North American Archaeologist 14(2):99-125.

Cooper, J. H. and E. S. Cooper

2005 Archaeological Investigations of 291 Acres at Mission Tejas State Park, Houston County, Texas. Report of Investigations No. 2004-06. C-Dimensions, Plano.

Corbin, J. E.

1991 Retracing the Camino de los Tejas from the Trinity River to Los Adaes: New Insights into East Texas History. In A Texas Legacy: The Old San Antonio Road and the Caminos Reales, a Tricentennial History, 1691-1991, edited by A. J. McGraw, J. W. Clark, and E. A. Robbins, pp. 191-219. Texas State Department of Highways and Public Transportation, Austin.

Creel, D. G.

1982 Artifacts of Non-Native Manufacture. In The Deshazo Site, Nacogdoches County, Texas, Volume 1, edited by D. A. Story, pp. 113-130. Texas Antiquities Permit Series, No. 7. Texas Antiquities Committee, Austin.

Cunningham, D. S. (editor)

2006 The Domingo Ramon Diary of the 1716 Expedition into the Province of the Tejas Indians: An Annotated Translation. Southwestern Historical Quarterly 110(1):39-67.

DeVore, S. L.

1992 Beads of the Bison Robe Trade: The Fort Union Trading Post Collection. Publication No. 1, Fort Union Monograph Series. Friends of Fort Union Trading Post, Williston, North Dakota.

Emerson, T. E. and R. E. Hughes

2001 De-Mything the Cahokia Catlinite Trade. Plains Anthropologist 46(175):149-161. 
Erickson, E. C. and J. E. Corbin

1996 Archaeological Survey and Cultural Resource Assessment of Mission Tejas State Historical Park, Houston County, Texas. Public Lands Division, Cultural Resource Program, Texas Parks and Wildlife Department, Austin.

Espinosa, Fray Isidro Felis de

1927 Descriptions of the Tejas or Asinai Indians, 1691-1722. Translated by M. A. Hatcher. Southwestern Historical Quarterly 31:150-180.

Foster, W. C. (editor)

1998 The La Salle Expedition to Texas: The Journal of Henri Joutel, 1684-1687. Texas State Historical Association, Austin.

Galan, V.

2003 Cultural Resources Survey of the Temple-Inland Tract Floodplain, Houston County, Texas. Deep East Texas Archaeological Consultant, Nacogdoches, Texas.

Girard, J. S.

1995 The Chipped Stone Collection: Technological, Functional, and Typological Analyses. In The Deshazo Site, Nacogdoches County, Texas, Vol. 2, edited by D. A. Story, pp. 33-156. Studies in Archeology 21. Texas Archeological Research Laboratory, The University of Texas at Austin.

Good, C. E.

1982 Analysis of Structures, Burials, and Other Cultural Features. In The Deshazo Site, Nacogdoches County, Texas, Volume 1, edited by D. A. Story, pp. 51-110. Texas Antiquities Permit Series 7. Texas Antiquities Committee, Austin.

Gregory, H. F.

1973 Eighteenth Century Caddoan Archaeology: A Study in Models and Interpretation. Ph.D. dissertation, Department of Anthropology, Southern Methodist University, Dallas.

Gregory, H. F. and C. H. Webb

1965 European Trade Beads from Six Sites in Natchitoches Parish, Louisiana. The Florida Anthropologist 18(3):15-44.

Hamilton, T. M.

1979 Guns, Gunflints, Balls and Shot. In Tunica Treasure, by J. P. Brain, pp. 206-216. Papers of the Peabody Museum of Archaeology and Ethnology, Volume 71. Peabody Museum of Archaeology and Ethnology, Harvard University, Cambridge.

Harris, R. K. and I. M. Harris

1967 Trade Beads, Projectile Points, and Knives. In A Pilot Study of Wichita Indian Archeology and Ethnohistory, assembled by R. E. Bell, E. B. Jelks, and W. W. Newcomb, pp. 129-162. Final Report for Grant GS-964, National Science Foundation, Washington, D.C.

Harris, R. K., I. M. Harris, J. C. Blaine, and J. Blaine

1965 A Preliminary Archeological and Documentary Study of the Womack Site, Lamar County, Texas. Bulletin of the Texas Archeological Society 36:287-363.

Hunter, D. G.

1990 The Apalachee on Red River, 1763-1834: An Ethnohistory and Summary of Archaeological Testing at the Zimmerman Hill Site, Rapides Parish, Louisiana. Louisiana Archaeology 12:7-127.

Jackson, J.

1999 Shooting the Sun: Cartographic Results of Military Activities in Texas, 1689-1829.2 Vols. The Book Club of Texas, Lubbock. 
Jackson, R. H.

2004 Congregation and Depopulation: Demographic Patterns in the Texas Missions. Journal of South Texas 17(2):7-38.

2005 Missions and the Frontiers of Spanish America: A comparative study of the impact of environmental, economic, political, and socio-cultural variations on the missions in the Rio de la Plata region and on the Northern Frontier of New Spain. Pentacle Press, Scottsdale, Arizona.

Jelks, E. B. (editor)

1967 The Gilbert Site: A Norteno Focus Site in Northeastern Texas. Bulletin of the Texas Archeological Society $37: 1-248$.

Jenkins, J. H. (editor)

1987 Recollections of Early Texas: The Memoirs of John Holland Jenkins. University of Texas Press, Austin.

Karklins, K.

1985 Glass Beads: The 19 $9^{\text {th }}$ Century Levin Catalogue and Venetian Bead Book and Guide to Description of Glass Beads. Studies in Archaeology, Architecture and History, National Historic Parks and Sites Branch, Parks Canada, Ottawa, Ontario.

Kenmotsu, N. A.

1990 Gunflints: A Study. Historical Archaeology 24(2):92-125.

Kennedy, W.

1892 Houston County. In Papers Accompanying the Third Annual Report of the Geological Survey of Texas, edited by E. T. Dumble, pp. 12-13, 21. Henry Hutchins State Printer, Austin.

Kidd, K. E. and M. A. Kidd

1970 A Classification System for Glass Beads for the Use of Field Archaeologists. Occasional Papers in Archaeology and History No. 1, pp. 45-89. National Historic Sites Service, National and Historic Parks Branch, Department of Indian Affairs and Northern Development, Ottawa, Ontario.

Kleinschmidt, U. K. W.

1982 Review and Analysis of the A. C. Saunders Site, 41AN19, Anderson County, Texas. Master's thesis, Department of Anthropology, The University of Texas at Austin.

McGraw, A. J., J. W. Clark, and E. A. Robbins (editors)

1991 A Texas Legacy: The Old San Antonio Road and the Caminos Reales, a Tricentennial History, 1691-1991. Texas State Department of Highways and Public Transportation, Austin.

Middlebrook, T.

2007 A Survey of Historic Caddo Sites in Nacogdoches County. Journal of Northeast Texas Archaeology 26:99115.

Mitchem, J.

1993 Beads and Pendants from San Luis de Talimali: Inferences from Varying Contexts. In The Spanish Missions of La Florida, edited by B. G. McEwan, pp. 399-417. University Press of Florida, Gainesville.

Napoleon, P. N.

1995 Analysis of Native-Made Pipes. In The Deshazo Site, Nacogdoches County, Texas, Volume 2: Artifacts of Native Manufacture, edited by D. A. Story, pp. 157-171. Studies in Archeology 21. Texas Archeological Research Laboratory, The University of Texas at Austin.

Neighbours, K. E.

1973 Indian Exodus: Texas Indian Affairs, 1835-1859. Nortex Offset Publications, Quannah.

1975 Robert Simpson Neighbors and the Texas Frontier, 1836-1859. Texian Press, Waco. 
Newell, H. P and A. D. Krieger

1949 The George C. Davis Site, Cherokee County, Texas. Memoir No. 5. Society for American Archaeology, Menasha, Wisconsin.

Perttula, T. K.

2011 The Ceramic Artifacts from the Lang Pasture Site (41AN38) and the Place of the Site within an Upper Neches River Basin Caddo Ceramic Tradition. In Archeological Investigations at the Lang Pasture Site (41AN38) in the Upper Neches River Basin of East Texas, assembled and edited by T. K. Perttula, D. B. Kelley, and R. A. Ricklis, pp. 145-320. Archeological Studies Program Report No. 129, Texas Department of Transportation, Environmental Affairs Division, Austin.

2015a 41HO70 on Stowe Creek in the upper San Pedro Creek Basin, Houston County, Texas. Journal of Northeast Texas Archaeology 54:35-40.

2015b Caddo Archaeological Sites on San Pedro Creek in Houston County, Texas: San Pedro de los Nabedaches. Journal of Northeast Texas Archaeology 53:65-82.

Perttula, T. K., with contributions by T. E. Emerson and R. E. Hughes

2004 41HO64/41HO65, Late 17th to Early 18th Century Caddo Sites on San Pedro Creek in Houston County, Texas. Bulletin of the Texas Archeological Society 75:85-103.

Perttula, T. K. and R. L. Cast

2010 Defining and Publicizing the Caddo Presence along El Camino Real de los Tejas in East Texas: A Research Strategy to Identify $17^{\text {th }}$-early $19^{\text {th }}$ Century Caddo Sites. Cultural Preservation Program, Caddo Nation of Oklahoma, Binger.

Perttula, T. K. and B. Nelson

2006 Test Excavations at Three Caddo Sites at Mission Tejas State Park, Houston County, Texas. Report of Investigations No. 76. Archeological \& Environmental Consultants, LLC, Austin.

2007a Archeological Investigations in 2007 at Mission Tejas State Park in Houston County, Texas. Report of Investigations No. 85. Archeological \& Environmental Consultants, LLC, Austin.

2007b Place of the Blackberry: Historic Nabedache Caddo Archeology at Mission Tejas State Park, Houston County, Texas. Current Archeology in Texas 9(1):1-11.

Perttula, T. K., L. L. Bush, L. Schniebs, T. Middlebrook, and P. S. Marceaux

2010 An Early Historic Caddo Farmstead at the Henry M. Site (41NA60) in Nacogdoches County, Texas. Stephen F. Austin State University Press, Nacogdoches.

Perttula, T. K., B. Nelson, and M. Walters

2011 Archeological Survey Investigations to Identify $17^{\text {th }}$-early $19^{\text {th }}$ Century Caddo Sites along El Camino Real de los Tejas National Historic Trail in East Texas. Report of Investigations No. 108. Archeological \& Environmental Consultants, LLC, Austin.

Perttula, T. K., M. Walters, and B. Nelson

2007 Decorated Ceramic Vessel Sherd Collection, Mission Tejas State Park Area, Houston County, Texas. MS on file. Archeological \& Environmental Consultants, LLC, Austin.

Ricklis, R. A.

1994 Aboriginal Life and Culture on the Upper Texas Coast: Archaeology at the Mitchell Ridge Site, 41GV66, Galveston Island. Coastal Archaeological Research, Inc., Corpus Christi.

Rogers, J. D. and G. Sabo III

2004 Caddo. In Handbook of North American Indian, Volume 14, Southeast, edited by R. D. Fogelson, pp. 616-631. Smithsonian Institution, Washington, D.C.

Rogers, R., M. A. Nash, and T. K. Perttula

2001 Excavations at the Herman Bellew Site (41RK222), Rusk County, Texas. PBS\&J, Austin. 
Ross, L. A.

2000 Trade Beads from Archeological Excavations at Fort Union Trading Post National Historic Site. National Park Service, Midwest Archeological Center, Lincoln, Nebraska.

Schambach, F. F.

1982 An Outline of Fourche Maline Culture in Southwest Arkansas. In Arkansas Archeology in Review, edited by N. L. Trubowitz and M. D. Jeter, pp. 132-197. Research Series No. 15. Arkansas Archeological Survey, Fayetteville.

1998 Pre-Caddoan Culture in the Trans-Mississippi South: A Beginning Sequence. Research Series No. 53. Arkansas Archeological Survey, Fayetteville.

Smith, F. T.

1995 The Caddo Indians: Tribes at the Convergence of Empires, 1542-1854. Texas A\&M University Press, College Station.

Smith, M. P

1983 Chronology from Glass Beads: The Spanish Period in the Southeast, c. A.D. 1513-1670. In Proceedings of the 1982 Glass Trade Bead Conference, edited by C. F. Hayes III, pp. 147-158. Research Records No. 16. Rochester Museum \& Science Center, Rochester, New York.

1987 Archaeology of Aboriginal Culture Change in the Interior Southeast: Depopulation during the Early Historic Period. University Presses of Florida, Gainesville.

1990 Glass Beads from the Goldsmith Oliver 2 Site. In Goldsmith Oliver 2 (3PU306): A Protohistoric Archeological Site near Little Rock, Arkansas, by M. D. Jeter, K. H. Cande, and J. J. Mintz, pp. 217-223. AAS Project Nos. 631 and 656 Report. Arkansas Archeological Survey, Fayetteville.

2002 Eighteenth-Century Glass Beads in the French Colonial Trade. Historical Archaeology 36(1):55-61.

Story, D. A.

1990 Cultural History of the Native Americans. In The Archeology and Bioarcheology of the Gulf Coastal Plain, by D. A. Story, J. A. Guy, B. A. Burnett, M. D. Freeman, J. C. Rose, D. G. Steele, B. W. Olive, and K. J. Reinhard, pp. 163-366. Research Series No. 38. 2 Vols. Arkansas Archeological Survey, Fayetteville.

Story, D. A. (editor)

1982 The Deshazo Site, Nacogdoches County, Texas, Volume 1. Texas Antiquities Permit Series 7. Texas Antiquities Committee, Austin.

1995 The Deshazo Site, Nacogdoches County, Texas, Volume 2. Studies in Archeology 21. Texas Archeological Research Laboratory, The University of Texas at Austin.

Story, D. A. and D. G. Creel

1982 The Cultural Setting. In The Deshazo Site, Nacogdoches County, Texas, Volume 1, edited by D. A. Story, pp. 20-34. Texas Antiquities Permit Series 7. Texas Antiquities Committee, Austin.

Suhm, D. A. and E. B. Jelks (editors)

1962 Handbook of Texas Archeology: Type Descriptions. Special Publication No. 1, Texas Archeological Society, and Bulletin No. 4, Texas Memorial Museum, Austin. Reprinted in 2009, Gustav's Library, Davenport, Iowa.

Swanton, J. R.

1942 Source Material on the History and Ethnology of the Caddo Indians. Bulletin 132. Bureau of American Ethnology, Smithsonian Institution, Washington, D.C.

Teltser, P. A.

1993 An Analytic Strategy for Studying Assemblage-Scale Ceramic Variation: A Case Study from Southeast Missouri. American Antiquity 58(3): 530-543. 
Wade, M. F.

2008 Missions, Missionaries, and Native Americans: Long-Term Processes and Daily Practices. University Press of Florida, Gainesville.

Weddle, R. S.

2012 Archival and Archaeological Research: Camino Real de los Tejas and Texas State Parks. Texas Parks and Wildlife Department, Austin.

Weddle, R. S., D. E. Chipman, and C. A. Lipscomb

2016 The Misplacement of Mission San Francisco de los Tejas in Eastern Texas and Its Actual Location at San Pedro de los Nabedaches. MS under review by Southwestern Historical Quarterly, 120(1):74-84.

Wells, T.

1998 Nail Chronology: The Use of Technologically Derived Features. Historical Archaeology 32(2):78-99.

Williams, J. M.

2007 GIS Aided Archaeological Research of El Camino Real de Los Tejas with Focus on the Landscape and River Crossings along El Camino Carretera. Masters thesis, Stephen F. Austin State University, Nacogdoches.

Wisseman, S. U., D. E. Moore, R. E. Hughes, M. R. Hynes, and T. E. Emerson

2002 Mineralogical Approaches to Sourcing Pipes and Figurines from the Eastern Woodlands, U.S.A. Geoarchaeology 17(7):689-715.

Woldert, A. E.

1935 The Location of the Tejas Indian Villages (San Pedro) and the Spanish Missions in Houston County. Southwestern Historical Quarterly 38(3):203-212.

Wray, C. F.

1983 Seneca Glass Trade Beads, c. A.D. 1550-1820. In Proceedings of the 1982 Glass Trade Bead Conference, edited by C. F. Hayes III, pp. 41-49. Research Records No. 16. Rochester Museum \& Science Center, Rochester, New York. 